Florida International University

FIU Digital Commons

FIU Electronic Theses and Dissertations

University Graduate School

$11-9-2005$

\title{
The international legal thought of Carl Schmitt : towards a critique of the contemporary international order
}

Alex D. Barder

Florida International University

DOI: $10.25148 /$ etd.FI14050428

Follow this and additional works at: https://digitalcommons.fiu.edu/etd

Part of the International and Area Studies Commons

\section{Recommended Citation}

Barder, Alex D., "The international legal thought of Carl Schmitt : towards a critique of the contemporary international order" (2005). FIU Electronic Theses and Dissertations. 1396.

https://digitalcommons.fiu.edu/etd/1396

This work is brought to you for free and open access by the University Graduate School at FIU Digital Commons. It has been accepted for inclusion in FIU Electronic Theses and Dissertations by an authorized administrator of FIU Digital Commons. For more information, please contact dcc@fiu.edu. 
FLORIDA INTERNATIONAL UNIVERSITY

Miami, Florida

THE INTERNATIONAL LEGAL THOUGHT OF CARL SCHMITT: TOWARDS A CRITIQUE OF THE CONTEMPORARY INTERNATIONAL ORDER

A thesis submitted in partial fulfillment of the

$$
\begin{aligned}
& \text { requirements for the degree of } \\
& \text { MASTER OF ARTS } \\
& \text { in }
\end{aligned}
$$

INTERNATIONAL STUDIES

by

Alex D. Barder

2005 
To: Interim Dean Mark Szuchman

College of Arts and Sciences

This thesis, written by Alex D. Barder, and entitled The International Legal Thought of Carl Schmitt: Towards a Critique of the Contemporary International Order, having been approved in respect to style and intellectual content, is referred to you for judgment.

We have read this thesis and recommend that it be approved.

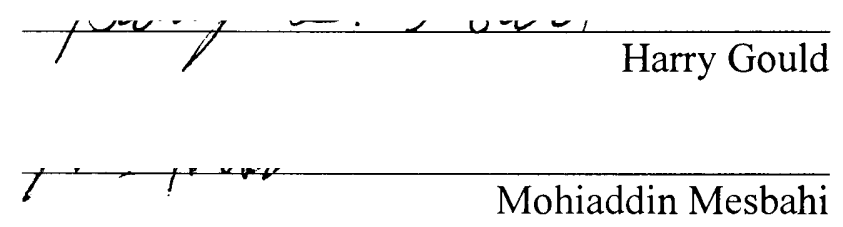

Patricia Price

Franeois Debrix, Major Professor

Date of Defense: November 9, 2005

The thesis of Alex D. Barder is approved.

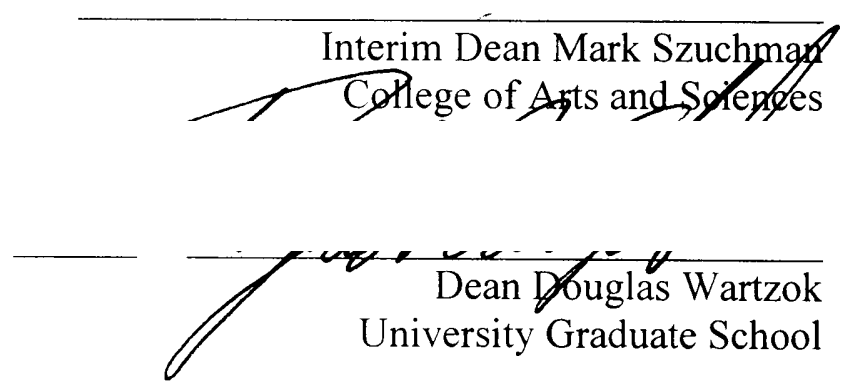

Florida International University, 2005 


\section{DEDICATION}

Je consacre ce travail à ma mère qui a toujours cru en moi. 


\section{ACKNOWLEDGMENTS}

This thesis would not have been possible without the consistent and kind support of my committee members. In particular, my major Professor François Debrix, who read thoroughly all the chapters while providing invaluable comments and suggestions. I must especially thank him for his patience with my sometimes-linguistic inaccuracies. Also I must thank his generosity in encouraging me to present at various conferences and to work towards publishing. Likewise, the independent study that I was part of with Professor Debrix and my colleague Jason Weidner was invaluable in teaching me how to carefully read a text. Also, a special thanks to Professor Harry Gould who as well read through all the chapters while I was composing them and provided critical comments and support. Professor Gould was instrumental in helping me to understand the various nuances in international legal orders. Professor Mohiaddin Mesbahi's lectures and office hours discussing conceptual issues provided me with my initial interest in theory and for that I am eternally grateful. Professor Price taught me to better look at the concept of place and how it remains coupled to political theory. The seminars on Heidegger and Space, Place, \& Identity were invaluable for opening my horizons. I must thank as well Professor Nicholas Onuf, whose seminars in theory and his initial reading of my conference paper on Carl Schmitt provided the motivation for probing deeper into international law and politics. I would also like to thank the International Relations department for providing a stellar environment for research and guidance. Special thanks to Mary Cossio and Martha Linares for their patience and help with administrative issues.

On a more personal note, I would not be where I am were it not for my dear friend Majid Al-Khalili. Majid was instrumental in setting me on the path of academic 
scholarship and, more importantly, looking at the world in a totally new manner. This work could not have been accomplished without the constant encouragement of my wife and friend Alla Mirzoyan. Her patience and generosity in reading my work facilitated the moments when I felt I was at an impasse. I owe the success of this thesis to her. 


\title{
ABSTRACT OF THE THESIS \\ THE INTERNATIONAL LEGAL THOUGHT OF CARL SCHMITT: TOWARDS A CRITIQUE OF THE CONTEMPORARY INTERNATIONAL ORDER
}

by

\author{
Alex D. Barder \\ Florida International University, 2005 \\ Miami, Florida \\ Professor Francois Debrix, Major Professor
}

The aim of the thesis is to develop a critique of current liberal conceptualizations of international order. In order to conduct this critique, this thesis revisits the arguments first put forth by the German legal and political theorist Carl Schmitt. Schmitt conceptualizes a tripartite unity between law, order, and place. This unity, established at the constituent moment of land-appropriation, forms a concrete nomos, which subsequently creates the contours of the legal and political order. The establishment of the concrete order is necessarily the construction of a territorial boundary that designates an inside and an outside of the polity. By speaking of a nomos of the earth, Schmitt globalized this understanding of concrete order by looking at the various historical developments that created a "line" between the concrete applicability of interstate norms and a region where the exceptional situation prevails. The critique presented in this thesis is concerned with the lack of concrete boundary conditions within the current international legal order. It is argued that this lack of a well-defined boundary condition is what results in extreme forms of violence that were traditionally bracketed. 


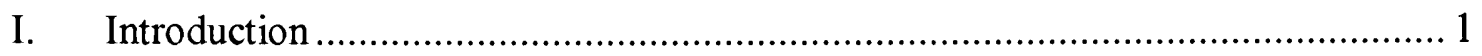

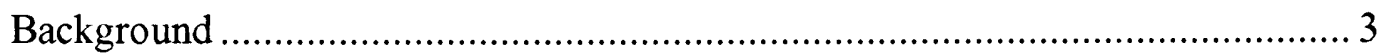

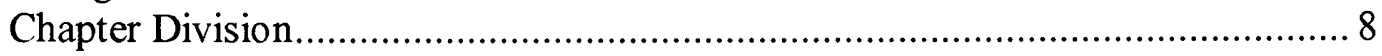

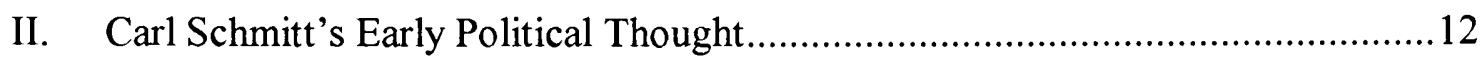

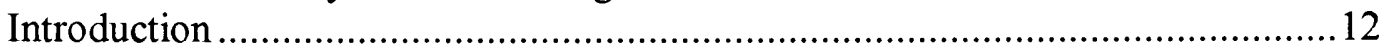

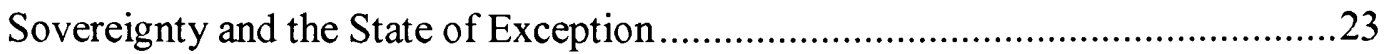

Political Friends and Enemies .........................................................................

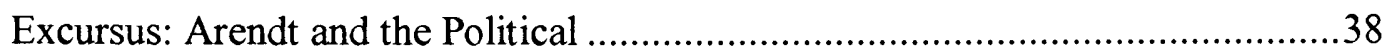

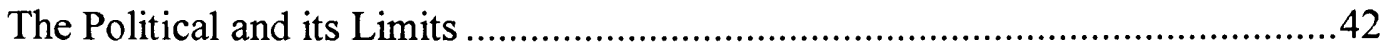

Leo Strauss's Commentary on Schmitt ..........................................................46

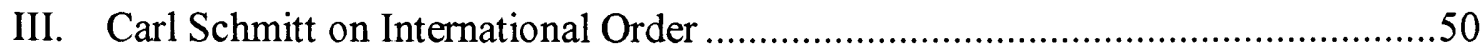

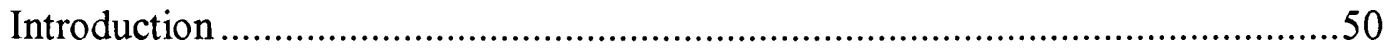

The Turn Towards International Law ...........................................................54

Excursus: Some Perspectives on International Law

Jurisprudence during the Inter-War Years ......................................................67

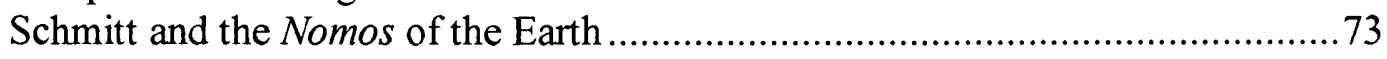

The Fall of the Jus Publicum Europaeum........................................................8

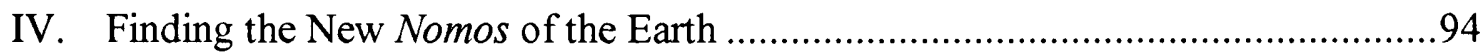

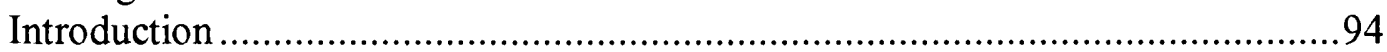

Against the Making of International Orders: Then and Now?.......................... 100

Excursus: The Kantian Retrieval, Habermas and Rawls

on the International Legal Order ....................................................................107

Finding a Nomos of the Earth: Schmitt's Concept of Grossraum ......................117

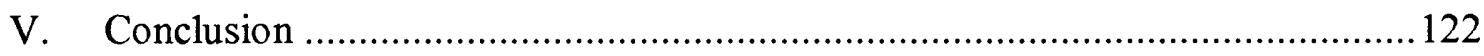

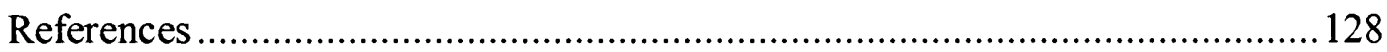




\section{Introduction}

The end of the great bipolar struggle between the United States and the Soviet Union resulted in the self-justified assertion that there no longer appears to be a rival ideological claim as to what constitutes the legitimate internal political and economic constitution of existence. This liberal-democratic triumphalism has certainly formed the guiding principle of contemporary US policy makers. The growing perception within the United States, beginning with the multilateral approaches of the Clinton administration and later in a much more overt way after the terrorist attacks of September 11, implied that the spread of democratic forms of government and Western values was crucial for the United States' long-term security. That the current US administration makes it a policy "to seek and support the growth of democratic movements and institutions in every nation and culture, with the ultimate goal of ending tyranny in our world" is the full realization of this totalizing worldview, not to mention a startling faith in democratic peace theory as well. ${ }^{1}$ Thus the international order has been radically perceived not in terms of the traditional Westphalian model of a set of distinct and equally recognized legally sovereign actors, but rather by way of the internal characteristics of these states as judged by the United States. External sovereignty has been devalued in favor of manichean moral dichotomies. As one American neo-conservative commentator writes in a striking formulation of the current international order, "...it is at last becoming clear, as

1 George W. Bush, Second Term Inaugural Address (2005 [cited 02/08/2005); available from http://www.whitehouse.gov/news/releases/2005/01/20050120-1.html, John R. Oneal and Russet Bruce, "The Pacific Benefits of Democracy, Interdependence, and International Organization, 1885-1992," World Politics 51, no. 1 (1999). 
well, that the new international order has a moral and even a religious dimension."2 The ominous implication of devising such an international order remains the possibility of criminalizing and dehumanizing the "other" who does not subscribe to the same universal ideology. The result is the absolutism of enmity and the potential unboundedness of armed conflict.

Political philosophical concepts such as freedom, democracy and liberalism dominate the public discourse as universal and quasi-transcendental categories. They become decoupled from the rooted historical and concrete contexts from which they emerged only to become floating signifiers. The current problematic of grounding an international order on an abstract normativism is a consequence of this lack of conceptual clarity. For example, a well-known philosophical justification for this perception is Francis Fukuyama's end of history thesis. ${ }^{3}$ For Fukuyama, the end of the cold war and the triumph of liberal democracy represent "the end of history" insofar as grand political experimentations and conflicts come to an end. ${ }^{4}$ He then makes the audacious claim that "there is a fundamental process at work that dictates a common evolutionary pattern for all human societies - in short, something like a Universal History of mankind in the direction of liberal democracy." This Hegelian inspired thesis, though refracted by Alexandre Kojève's Heideggerian interpretation of the dialectic of master and slave, is contingent upon the premise that liberal democracy satisfies the deepest longing of man;

\footnotetext{
${ }^{2}$ Michael Novak, "Global Liberty," National Review, January 20, 2005. My emphasis

${ }^{3}$ Francis Fukuyama, The End of History and the Last Man (Toronto: Free Press, 1992). The philosophical motivation for Fukuyama's work lies in Alexandre Kojève, Introduction to the Reading of Hegel, ed. Raymond Queneau (New York,: Basic Books, 1969).

${ }^{4}$ Fukuyama, The End of History and the Last Man. p. 211

${ }^{5}$ Ibid. p. 48 Authors italics
} 
that of recognition. ${ }^{6}$ Fukuyama dubiously attempts an ideational synthesis of an internal psychological trait - our internal thymos (self-esteem) - between megalothymia (the desire to be recognized as superior) and isothymia (the desire to be recognized as an equal). ${ }^{7}$ For Fukuyama's proposed synthesis reduces itself to the classical liberal ideal whereby the political - as an existential struggle for recognition - becomes displaced by the economic and social space of activity. This utilitarian mode of social interaction, which engenders the satisfaction of the material condition of man, becomes the telos necessary for the dialectic of master and slave to find its synthesis. ${ }^{8}$ The political struggle, in which difference clearly manifests itself, is thus transferred into a technical problem that can be solved. Fukuyama then abstracts this struggle for recognition between men to the sphere of international relations in order to make a case for a homogenous and peaceful community of states.

\begin{abstract}
If the advent of the universal and homogenous state means the establishment of rational recognition on the level of individuals living within society, and the abolition of the relationship of lordship and bondage between them, then the spread of that type of state throughout the international system of states should imply the end of the relationship of lordship and bondage between nations as well - i.e. the end of imperialism and with it, a decrease in the likelihood of wars based on imperialism. ${ }^{9}$
\end{abstract}

Fukuyama's formulation is taken as a clear example of the juxtaposition of a quasitheological, that is to say, eschatological claim with an assumption of escaping political conflict. Likewise, one finds this train of reasoning within Marxism, given that it posits the emergence of the proletarian revolution and global civil war, which would usher in a

\footnotetext{
${ }^{6}$ Ibid. p. 207; See Shadia B. Drury, Alexandre Kojève : The Roots of Postmodern Politics (New York: St. Martin's Press, 1994). pp. 179-198

${ }^{7}$ Fukuyama, The End of History and the Last Man. pp. 181-182

${ }^{8}$ Ibid. pp. $98-108$

${ }^{9}$ Ibid. p. 245
} 
classless society and, by consequence, a homogenous world. The German political and legal theorist Carl Schmitt has especially critiqued these two modern claims of emancipation from political conflict. Schmitt's work provides a useful template for seeing the flaws inherent in this type of reasoning and the perils of formulating foreign policy choices along such lines.

\section{Background}

There has been a considerable revival of interest in the political writings of the late German political and legal theorist Carl Schmitt. A prolific writer, Schmitt's works remain largely untranslated into English except for a few of his key books. Undoubtedly, his affiliation, albeit brief, with the Nazi party, and his status outside Germany as the Third Reich's leading jurist tarnished his reputation for a good number of years and made it more difficult for his works to be studied by a non-German speaking audience. ${ }^{10}$ It would be George Schwab's work in the 1960s that would first bring attention to Schmitt's writings in the United States. ${ }^{11}$ After his death in 1985, Schmitt's writings would gain greater appreciation within academia and within political groups in Europe and the United States. ${ }^{12}$

\footnotetext{
${ }^{10} \mathrm{He}$ was expelled from the Nazi party in 1936 after the discovery of a letter written by him to the former Weimar president Hidenburg urging in part the activation of Article 48 of the constitution in order to crush the Nazi and Communist parties and restore order within Germany. Carl Schmitt, The Leviathan in the State Theory of Thomas Hobbes: Meaning and Failure of a Political Symbol (Westport, Conn.: Greenwood Press, 1996). p. xvii; See also Joseph W. Bendersky, Carl Schmitt, Theorist for the Reich (Princeton, N.J.: Princeton University Press, 1983). Charles E. Frye, "Carl Schmitt's Concept of the Political," The Journal of Politics Vol. 28, no. 4 (1966).

${ }^{11}$ George Schwab, The Challenge of the Exception: An Introduction to the Political Ideas of Carl Schmitt between 1921 and 1936, 2nd ed., Contributions in Political Science, No. 248 (New York: Greenwood Press, 1989).

${ }^{12}$ See Mark Lilla, "The Enemy of Liberalism," The New York Review of Books, May 151997.
} 
Though known as a political conservative, even a reactionary political scholar in the tradition of counter-revolutionary writers such as Joseph De Maistre, Louis De Bonald and Juan Dononso-Cortés, Schmitt sought to establish a political and legal theory that could restore a semblance of order and security at a time of heightened instability. ${ }^{13}$ His body of work had at its core a continuous criticism of classical liberalism and the project of modernity that he held partly responsible for the catastrophes of the $20^{\text {th }}$ century. The particular historical period after World War I would motivate him, among others in Germany, to appropriate Thomas Hobbes's political theory in the hopes of grounding an internal stable political order. ${ }^{14}$ For some, however, Schmitt became heir to a particular German appropriation - starting with Fichte and Hegel - of a Machiavellism that would directly lead to the totalitarian state of Nazi Germany. ${ }^{15}$ For others, Schmitt represents the face of German militarism and the glorification of politics for the sake of politics. ${ }^{16}$ Certainly Schmitt follows in the tradition of Max Weber and the

13 Jeffrey Johnson situates Schmitt as a third generation counter-revolutionary writer where Joseph De Maistre is the first generation and Juan Donoso Cortes is the second. Juan Donoso Cortes, Selected Works of Juan Donoso Cortes, ed. Jeffrey P. Johnson, trans. Jeffrey P. Johnson (Westport: Greenwood Press, 2000). pp. 1-3

${ }^{14}$ Ferdinand Tönnies, Hobbes Leben Und Lehre (Stuttgart,: F. Frommanns verlag (E. Hauff), 1896). was one of the most important texts to emerge in Germany and would be very influential on Schmitt and other post World War I German writers. See as well John P. McCormick, "Fear, Technology, and the State: Carl Schmitt, Leo Strauss and the Revival of Hobbes in Weimar and National Socialist Germany," Political Theory Vol. 22, no. 4 (1994), Schmitt, The Leviathan in the State Theory of Thomas Hobbes: Meaning and Failure of a Political Symbol, Leo Strauss, The Political Philosophy of Hobbes: Its Basis and Its Genesis (Chicago: University of Chicago Press, 1984).

${ }^{15}$ Marck Siegfried, "Neo-Machiavellism and Ethical Nihilism," Ethics Vol. 51, no. 2 (1941). p. 195; For a detailed study of Machiavelli and a historiography of Realpolitik in German political thought see Friedrich Meinecke, Machiavellism: The Doctrine of Raison D'etat and Its Place in Modern History (New Brunswick, N.J.: Transaction Publishers, 1998). Ernst Cassirer, The Myth of the State (New Haven: Yale university press, 1946). pp. 116-162

${ }^{16}$ Richard Wolin, "Carl Schmitt: The Conservative Revolutionary Habitus and the Aesthetics of Horror," Political Theory Vol. 20, no. 3 (1992). As well William E. Scheuerman in comparing and contrasting the respective realisms of Morgenthau and Schmitt argues that Schmitt represents a "Realism of War" to Morgenthau's "Realism of Peace". William E. Scheuerman, Carl Schmitt: The End of Law (Lanham: 
Kriegsideologie of post World War I German thinking. ${ }^{17}$ In particular, his connection to Leo Strauss and the current neo-conservative political movement in the United States has already been commented on. ${ }^{18}$

However, this revivalism of Schmitt is not limited to neo-conservative political thought seen in the United States for instance. Though Schmitt was noted for his conservative leanings, articles concerning his work have been appearing in the wellknown Frankfurt School leaning journal Telos. ${ }^{19}$ Numerous references by two leading neo-Marxist scholars Michael Hardt and Antonio Negri to Schmitt's work point to the current desire to find conceptual tools that enable a rigorous way of critiquing modern liberalism and capitalistic universalism. ${ }^{20}$ Ellen Kennedy even goes so far as to claim that the Frankfurt School's own critiques - including Habermas's own work - of the enlightenment project and modern mass-democracy are actually derived from Schmitt's ideas. ${ }^{21}$ On the other hand, Habermas himself points to Schmitt's appeal to post-

Rowman \& Littlefield Publishers, 1999). p. 247

${ }^{17}$ Domenico Losurdo, Heidegger and the Ideology of War: Community, Death, and the West, trans. Jon and Marcella Morris (Amherst: Humanity Books, 2001).

${ }^{18}$ Shadia B. Drury, Leo Strauss and the American Right, 1st ed. (New York: St. Martin's Press, 1997). Anne Norton, Leo Strauss and the Politics of American Empire (New Haven Conn. ; London: Yale University Press, 2004). Heinrich Meier, Carl Schmitt \& Leo Strauss: The Hidden Dialogue (Chicago: University of Chicago Press, 1995), Heinrich Meier, The Lesson of Carl Schmitt: Four Chapters on the Distinction between Political Theology and Political Philosophy (Chicago: University of Chicago Press, 1998).

${ }^{19}$ Jan-Werner Müller, A Dangerous Mind: Carl Schmitt in Post-War European Thought (New Haven: Yale University Press, 2003). pp. 216-218 See as well Stephen Holmes, The Anatomy of Antiliberalism (Cambridge, Mass.: Harvard University Press, 1993). p. 37 for the relationship between Schmitt and the editors of Telos.

${ }^{20}$ Michael Hardt and Antonio Negri, Empire (Cambridge: Harvard University Press, 2000). pp. 16, $377-$ 378; Michael Hardt and Antonio Negri, Multitude: War and Democracy in the Age of Empire (New York: The Penguin Press, 2004). pp. 6, 72, 254, 330-331, 351, 359, 361, 370, 402

${ }^{21}$ Ellen Kennedy, "Carl Schmitt and the Frankfurt School," Telos 71 (1987). 
modern or post-structural theorists. ${ }^{22}$ For example, Jacques Derrida's The Politics of Friendship is an in-depth investigation of Schmitt's concept of the political in order to understand the relationship between community and society. ${ }^{23}$ Jean-Luc Nancy as well uses Schmitt's ideas as a way of understanding the discourse of humanitarian interventions in the early nineties starting with the first Gulf War. ${ }^{24}$ Most notably, Giorgio Agamben has used Schmitt's notions of sovereignty, as the ultimate decision in the exceptional situation, to uncover the modern "zones of indistinction" that fuse subjective technologies and political techniques. ${ }^{25}$ Building on Michel Foucault's conception of the modern emergence of biopolitics at the global level, Agamben through Schmitt demonstrates the evolution towards a modern nomos, that is, an order and orientation with a spatial reference culminating in the concentration camp. ${ }^{26}$ By implication, Agamben argues that the liberal goal of smoothing the "fractures" of the political space by way of a homogenization of the global body politic necessarily leads to a hyper-politicization and continues "the civil war that divides the people and the cities of the earth."27

22 Jürgen Habermas, "The Horrors of Autonomy: Carl Schmitt in English," in The New Conservatism : Cultural Criticism and the Historians' Debate (Cambridge: MIT Press, 1992). pp. 128-139

${ }^{23}$ Jacques Derrida, Politics of Friendship (New York: Verso, 1997).

24 Jean-Luc Nancy, "War, Right, Sovereignty - Techne," in Being Singular Plural (Stanford: Stanford University Press, 2000).

${ }^{25}$ Giorgio Agamben, Homo Sacer: Sovereign Power and Bare Life, trans. Daniel Heller-Roazen (Stanford, Calif.: Stanford University Press, 1998). p. 6

${ }^{26}$ Ibid, Giorgio Agamben, State of Exception, trans. Kevin Attell (Chicago: University of Chicago Press, 2005).

${ }^{27}$ Agamben, Homo Sacer: Sovereign Power and Bare Life. p. 180 
The claim in this thesis will be that any attempt to found an international political order on modern universal claims to truth are likely to lead to the very opposite goal of intensified warfare and instability. Carl Schmitt's writings touching upon legal and political theory will be especially illuminating in exposing the dubious propositions of a lasting international order based on liberal ideology. As demonstrated by the Frankfurt School and the editors of the journal Telos, or by the post-modern/post-structuralist theorists, not to mention neo-conservatives such as Leo Strauss, Schmitt's work represents an interesting starting point to develop a theoretical critique of the current hegemonic liberal-democratic universalism. What appeals to this spectrum of political groups and scholars is an inherent "right to difference", or the relativism of enmity, that is indeed explicit in Schmitt's understanding of the political conceived as the distinction between friend and enemy. ${ }^{28}$ Schmitt makes a clear distinction between public enemy and foe. "The enemy is hostis, not inimicus in the broad sense; polemos not echthros." foe or brigand by definition is a personal enemy that can be subject to dehumanization and criminalization. This "right to difference" is what later forms the heart of Schmitt's work on the history of the Jus Publicum Europaeum - the community of sovereign princes encompassing a set of norms contingent upon an understanding of territorial disjuncture - and the reasons for its subsequent collapse. It is with this in mind that the particular aim of this thesis will be to examine Schmitt's understanding of the political in

\footnotetext{
${ }^{28}$ Carl Schmitt, The Concept of the Political (Chicago: University of Chicago Press, 1996). p. 26

${ }^{29}$ Ibid. p. 28 My transliteration from Greek to Latin characters. In a footnote on p. 29 Schmitt quotes Forcellini Lexicon totius latinitatis, II, 684: "A public enemy (hostis) is one with whom we are at war publicly... In this respect he differs from a private enemy. He is a person with whom we have private quarrels. They may also be distinguished as follows: a private enemy is a person who hates us, whereas a public enemy is a person who fights us."
} 
its relationship to the rise and fall of the European state system. For Schmitt's understanding of what properly constitutes the ability to enact a stable international order is contingent upon an understanding of the primordial assumption of spatial ordering as land-appropriation or nomos. As Schmitt writes:

Every fundamental order is a spatial order...At the beginning of every great epoch, therefore there stands a great appropriation of the land. In particular, every important change and displacement of the picture of the world is bound with the world political changes and with a new division of the earth, a new appropriation of the land. ${ }^{30}$

My claim will be that the current attempts to refashion an international legal system not grounded in terms of a concrete order cannot but lead to the unrestrained violence witnessed throughout the $20^{\text {th }}$ century. Ultimately, Schmitt's arguments will shed light on the possible evolving geopolitical picture and on the idea of a stable international order that is opposed to notions of continuous liberal universalism.

\section{Chapter Division}

Chapter 1 will focus upon the early works (for the most part, prior to world war two) of Carl Schmitt. It was during this time period that Schmitt formulated his conception of sovereignty, the political, and his theory of the state. These formulations became the core concepts that would later guide his writings on international relations and law. Special focus will be placed here upon the relationship between Schmitt's definition of the political and the state of exception. The state of exception guides Schmitt's understanding of sovereignty and is contrasted with the prevailing legal positivistic approaches known as normativism. Schmitt's critiques of the universalistic

\footnotetext{
${ }^{30}$ Gopal Balakrishnan, The Enemy: An Intellectual Portrait of Carl Schmitt (New York: Verso, 2000). p. 243
} 
tendencies within liberalism and the foundational assumptions of the project of the enlightenment will be explored. This chapter will end by looking into the different readings of Hobbes by Schmitt and Leo Strauss. Hobbes remains consistently in the background in any reading of Schmitt. Thus, how Schmitt understands Hobbes will shed light on his theory of the state and on his narrative of the rise and fall of the European state-system.

Chapter 2 will explore Schmitt's latter work on international law and order. The basis of his claims will be investigated through an inquiry of the emergence and collapse of the European legal order. Also important to note is the way Schmitt differentiates between the legal orders associated with land of with sea. The legal order known as the Jus Publicum Europaeum in the end becomes contingent upon a land appropriation in the western hemisphere. There arises a clear demarcation between the inside of the European state-system as a "concrete spatial order" encompassing a set of rules bracketing conflict, and the outside where a Hobbesian state of nature reigns between great powers. This chapter will focus, in particular, on this relationship between the inside and outside of the Jus Publicum Europaeum and how it evolves over time. An additional concern will be to substantiate Schmitt's claims that the rise of the United States as a great power beginning with the Monroe doctrine decoupled the international legal order with its traditional demarcation of sovereignty.

Chapter 3 will then elucidate the critique of the current conception of international order. In particular, the aim will be to show the persistent problems associated with conceiving of a violence not grounded in a concrete order. This chapter will also look at the contemporary works of Jürgen Habermas and John Rawls to illustrate the problematic 
nature of how these scholars present the concepts of war and peace. Rather than relying upon abstract universal claims to legitimize a particular liberal understanding of difference in the international system, the claim will revolve around the Schmittian solution of a global Grossraum system. The establishment of this system through spatially centered configurations will allow for a grounding of international law that is distinct from traditional positive international legal approaches. 


\section{Carl Schmitt's Early Political Thought}

I Introduction

Germany's defeat in World War One marked the beginning of a period of constant difficulties in maintaining law and order. The newly established Weimar republic was hard pressed to assert its authority in the face of growing challenges to its legitimacy. Economically, Germany was hit with a crippling hyperinflation and economic depression that would subsequently legitimize extreme political groups vying for power. The political and economic context of post-war Germany stimulated what some have termed a "conservative revolution" in German intellectual thinking. ${ }^{1}$ This revolution extended its polemic not only against the principles of the liberal-democratic Weimar Republic, but also against the ideals embodied in the Enlightenment and the French Revolution. ${ }^{2}$ These "conservatives" take the year 1789 with the destruction of the ancien régime to be the beginning of a progressive infusion of liberal bourgeois escapism from conflict that accentuates the quest for security and peace through commerce. The merchant class becomes viewed as the very embodiment of the passivity and decadence in which modern society manifests its weakness. Such conservative intellectuals as Ernst Jünger and his brother Friedrich Georg, Arthur Moeller van den Bruck, Hans Zehrer, and Wilhelm Stapel among others would point to this feeling of continuous rootlessness and disenchantment with the modern world. Max Weber too spoke of a continuing "disenchantment of the world" (Entzauberung der Welt) resulting from the unremitting

\footnotetext{
${ }^{1}$ Roger Woods, The Conservative Revolution in the Weimar Republic (New York: St Martins Press, 1996).

${ }^{2}$ Ibid. p. 1
} 
bureaucratization of the political and social sphere. This interesting mixture of Edmund Burke's conservatism with an aestheticism and nostalgia for a mythic past plays a great part in these writings. The myth in conjunction with the aesthetic retrieval of Tacitus's Germania for example, and the idea of the nobility of the ancient Germanic warrior against the Roman (French) lassitude towards conflict is retrieved for contemporary polemical value. The purity of the aesthetic whole is sought over the plurality and heterogeneity of the body politic. ${ }^{3}$ This notion of aesthetic politics combined with Oswald Spengler's famous thesis of the continuous decline of the west provoked at the time a considerable angst that could only be assuaged through a continuous cycle of conflict, destruction and revival. ${ }^{4}$ Around this time Thomas Mann, for example, would coin the term Kriegsideologie ("ideology of war") as a way of describing the particular German romanticism associated with battle and the tragic hero. ${ }^{5}$ This Kriegsideologie that sought to embody the German spirit and community (Gemeinschaft) - as opposed to society, which became viewed as a great instrumental machine - through sacrifice, struggle, death, and destiny would become emblematic of an ideological and spiritual pathology paving the way for the emergence of National Socialism. ${ }^{6}$

This particular political and intellectual context within post war Germany would to a great extent shape the political thinking of Carl Schmitt. This chapter seeks to

\footnotetext{
${ }^{3}$ On the relationship between the philosophy of aesthetics and German political thought see Joseph Chytry, The Aesthetic State: A Quest in Modern German Thought (Berkeley: University of California Press, 1989).

${ }^{4}$ Oswald Spengler, The Decline of the West, trans. Charles Francis Atkinson (New York,: A., 1926).

${ }^{5}$ Dennis Schmidt has commented on the historical relationship between Greek tragedy and its particular Germanic appropriation through Hegel, Hölderlin, Heidegger, and Nietzsche as a way of retrieving a primodial understanding of the meaning of community, politics, and ethics. See Dennis J. Schmidt, On Germans \& Other Greeks: Tragedy and Ethical Life (Bloomington: Indiana University Press, 2001).
}

${ }^{6}$ Losurdo, Heidegger and the Ideology of War: Community, Death, and the West. pp. 11-29 
illustrate the set of concepts that are present within Schmitt's work until the late 1930s. Above all, the theme that stands out throughout Schmitt's writings during this period is a consistent desire to articulate the importance of the responsibility of the state (as the primary vehicle for maintaining political authority and order) relative to other social spheres of activity within civil society. The state, for Schmitt, becomes the embodiment of a sovereign will able to decide and harmonize political conflicts that cannot be subsumed within any internal legal formalism. Similarly, the sovereign decision finds its ultimate rationale in the ability to determine the existential dangers posed to the state. As will be seen, it is the recognition of the "other" as the public enemy through the ability to delineate difference that determines the essence of what is the political. Any subsequent undermining of the institution of the state or of the myth associated with the power of the leviathan over the commonwealth can only lead to a return to the state of nature, the destruction of the polity by the "other", and a bellum omnium contra omnes.

Historically, Schmitt associates the degeneracy of the conceptions of state and the political with the predominant liberal emphasis on the privatization of the "self" seen not only within European bourgeoisie, but also in the specifically German political romantic movement in the $19^{\text {th }}$ century. This romantic movement that finds its roots in the Rousseauism of the French Revolution, though critical of the liberal-bourgeois order, in fact accentuates it through its own inward turn. ${ }^{7}$ For the political romantic, experiences become mere "occasions" of aesthetic responsiveness. The political romantic lacks any spiritual core that could bring about decisive action. This romantic movement, wholly

\footnotetext{
${ }^{7}$ Carl Schmitt, Political Romanticism (Cambridge: MIT Press, 1986). pp. 25-33
} 
dependant on the triumph of liberalism, refracts political realities through this privatization of appearances. The result, as Schmitt characterizes it, is that "in the liberal, bourgeois world, the individuated, isolated, and emancipated individual becomes the middle point, the court of resort, the absolute." ${ }^{8}$ While the romantic refuses to make a political decision, with parody, Schmitt argues that liberal, faced with the choice; "Christ or Barabbas, ...answers with a motion to adjourn the meeting or set up an investigative committee." Thus, Schmitt polemicizes against this conflation of romanticism and liberalism for the explicit purpose of reestablishing a proper understanding of the inherent "seriousness" of what is subsequently the political. Schmitt in fact laments the emergence of liberalism as the dominant political modality in modern society precisely because liberalism, in its notion of the autonomy of the individual and its focus on compromise, discussion, and the atomization of society into its constituent members, puts forth a veil of ignorance over what properly constitutes the nature of the political. Indeed, Karl Löwith describes Schmitt's concern with the emergence of liberalism as that of defining a "politically neutral ground" that engenders a "depoliticization of the state." 10 Leading to this neutralization of the state is in part the progressive instrumentalization of the political into an empty legal formalism. Schmitt's polemics against romanticism, liberalism, and more generally the project of modernity revolve around the perception that this state of affairs ultimately leads to political paralysis. More generally, modernity as the locus of

\footnotetext{
${ }^{8}$ Ibid. p. 99

${ }^{9}$ Carl Schmitt, The Crisis of Parliamentary Democracy, Studies in Contemporary German Social Thought (Cambridge, Mass.: MIT Press, 1985). p. xvi

${ }^{10}$ Karl Löwith, "The Occasional Decisionism of Carl Schmitt," in Martin Heidegger and European Nihilism, ed. Richard Wolin (New York: Columbia University Press, 1995). p. 138
} 
technological progress as the point of emergence of instrumental rationality becomes responsible for the growing perception of a loss of meaning and nihilism. In one of his early essays, Schmitt express this disenchantment with modernity:

This age characterizes itself as capitalistic, mechanistic, relativistic; as the age of commerce, technology, and organization. In fact the 'factory' appeared to give the age its signature. As the imposing of functional means towards some wretched and senseless purpose, as the universal urgency of means over ends, the factory so nullified the individual that not once did he recognize his eradication. ${ }^{11}$

Later, in his famous lecture, "The Age of Neutralizations and Depoliticizations" delivered at Barcelona in 1929, Schmitt returns to this theme of technological progress and innovation as chimeras that deflect attention from the "reality" of the political. ${ }^{12}$ Schmitt makes a historicist argument in which, over the last four centuries, a continuous process of societal neutralization has occurred. In other words, a domain that encompasses a set of contentious political concepts is steadily displaced by the emergence of new set of concepts. Starting in the $17^{\text {th }}$ century with the transformation from contentions in theology to metaphysics; continued in the $18^{\text {th }}$ century with the evolution of metaphysics into a humanitarian moral (as the age of moral philosophical concepts from Hume to Kant); and ended in the $19^{\text {th }}$ century with the passage from the humanitarian to the economic. Each phase subsequently "neutralized" the other as in the case of theology becoming "uninteresting and merely private matters." 13 The evolution to the modern neutral ground of technology gives to its perceived ability to displace the state. Yet the neutralization of the state through an appeal to functional neutrality in

${ }^{11}$ Quoted from John P. McCormick, Carl Schmitt's Critique of Liberalism: Against Politics as Technology (Cambridge: Cambridge University Press, 1997). p. 42

${ }^{12}$ Carl Schmitt, "The Age of Neutralizations and Depoliticizations," Telos, no. 96 (1993 (1929)).

${ }^{13}$ Ibid. p. 137 
technology simply accentuates the political in different ways because technology's ability to be appropriated for political ends. ${ }^{14}$

Interestingly, the German-Jewish political theorist Hannah Arendt addresses a similar polemic against the modern world and the implications for understanding political action. In a similar vein, Arendt's claim that "World alienation... has been the hallmark of the modern age" reflects her perception of a modern age that subsumes all political questions under economic/utilitarian means. ${ }^{15}$ In other words, Arendt's awareness of "the rise of the social" is an affirmation that the realm of the household (i.e. the realm of productive and instrumental fabrication or that of homo faber) has taken over the political space. The supremacy of the material reality brought on by modernity cannot replace the necessity for an "in-between" place to bring together human beings since this reality places a primacy on "household" concerns, and in particular establishes the triumph of labor and work over genuine political action. Production and consumption, the hallmarks of the modern capitalistic utilitarianism, engender a "limitless instrumentalization of

\footnotetext{
${ }^{14}$ Ibid. p. 139; The nexus between modernity and technology is a common theme among various German writers from different sides of the political spectrum. One of the most famous works on the very nature of technology in the modern world remains Martin Heidegger, The Question Concerning Technology and Other Essays, trans. William Lovitt (New York: Harper \& Row, 1977). As well, his teacher, Edmund Husserl's famous text The crisis of European sciences and transcendental phenomenology tackles the issues of the nature of science and technology and its effects on modernity's consciousness. Edmund Husserl, The Crisis of European Sciences and Transcendental Phenomenology: An Introduction to Phenomenological Philosophy (Evanston,: Northwestern University Press, 1970). And in the Frankfurt School tradition Max Horkheimer and Theodor W. Adorno, Dialectic of Enlightenment: Philosophical Fragments, trans. Gunzelin Schmid Noerr (Stanford: Stanford University Press, 2002).; For an expose of the theme of technology in the writings of Heidegger, Marcuse, Foucault and Habermas see Andrew Feenberg, Questioning Technology (New York: Routledge, 1999).

${ }^{15}$ Hannah Arendt, The Human Condition, 2nd ed. (Chicago: University of Chicago Press, 1998). p. 254; See Dana Richard Villa, Arendt and Heidegger: The Fate of the Political (Princeton: Princeton University Press, 1996). pp. 188-201; Dana Richard Villa, Politics, Philosophy, Terror: Essays on the Thought of Hannah Arendt (Princeton: Princeton University Press, 1999). pp. 130-137 \& 190-191; Bonnie Honig, Political Theory and the Displacement of Politics, Contestations (Ithaca: Cornell University Press, 1993). pp. 123-125; Maurizio Passerin d'Entráeves, The Political Philosophy of Hannah Arendt (London ; New York: Routledge, 1994).Chapter 1; Seyla Benhabib, The Reluctant Modernism of Hannah Arendt (Thousand Oaks: Sage Publications, 1996). pp. 49, 55, 66-67
} 
everything that exists."16 The emergence of modern "worldlessness", as Dana Villa puts it, "is experienced as a kind of homelessness, a lack of place that results from the modern destruction of the durability of the 'human artifice'."17 At the heart of this growing sense of worldlessness is the deprivation of an authentic public "reality" as a result of a Cartesian retreat into the self. ${ }^{18}$ This retreat grounds epistemology, through the representation of the "real" by mathematical science, as the only certain methodology for truth disclosure. As Arendt writes, "what men have in common is not the world but the structure of their minds." 19 This achievement of internalizing the Archimedean point, that point selected "outside the earth" and "applied to earthly nature and the human artifice", results in an inherent will to power. ${ }^{20}$

Unlike Arendt however, Schmitt originally sought to formulate a theological critique of the modern age. His early work is consistently linked to a catholic conservatism that originates in his own provincial background. ${ }^{21}$ It should be noted that, even during this period, memories of the 1871 Kulturkampf between Bismarck and the Catholic Church remain fresh. Renato Cristi, for example, argues that Schmitt sought to "rescue" German conservatism from a subjective romanticism inherent German idealism

\footnotetext{
${ }^{16}$ Arendt, The Human Condition. p. 157

${ }^{17}$ Villa, Arendt and Heidegger: The Fate of the Political. p. 171

${ }^{18}$ Ibid. p. 194; Arendt, The Human Condition. p. 279

${ }^{19}$ Arendt, The Human Condition. p. 293

${ }^{20}$ Ibid. pp. 268-269

${ }^{21}$ Balakrishnan, The Enemy: An Intellectual Portrait of Carl Schmitt. p. 12-13
} 
that tries to pass itself of as a form of provincial conservatism. ${ }^{22}$ This subjective romanticism, as Schmitt argues, becomes responsible for a form of playful aestheticism and lack of seriousness that clouds a concrete understanding of political concepts such as authority, state, and sovereignty. By consequence, Cristi argues that Schmitt originally sought to rearticulate a brand of conservatism centered around the Catholic Church which "had preserved intact an awareness of the political and had kept faith in the true meaning of authority."23 Schmitt's 1917 essay, Roman Catholicism and Political Form, meant in part as a reply to Weber's The Protestant Ethic and the 'Spirit' of Capitalism, was an indictment of the modern (i.e., the secularized Protestant primacy of 'privacy' and the concept of predestination) form of scientific and economic/capitalistic rationalism that displaces a proper understanding of the political requirements of the time. ${ }^{24}$ By consequence, Schmitt viewed Soviet Russia as the antithesis to a Europe that progressively reduces itself to the passivity of commerce and entertainment. ${ }^{25}$ Interestingly, in light of his subsequent conception of the political as the disjunctive concrete facticity between friends and enemies, Schmitt writes in this same essay: "To

22 Renato Cristi, Carl Schmitt and Authoritarian Liberalism: Strong State, Free Economy, Political Philosophy Now (Cardiff: University of Wales Press, 1998). p. 55

${ }^{23}$ Ibid. p. 75

${ }^{24}$ Carl Schmitt, Roman Catholicism and Political Form, trans. G. L. Ulmen (Westport: Greenwood Press, 1996), Max Weber, The Protestant Ethic and the "Spirit" of Capitalism and Other Writings, ed. P. R. Baehr, trans. Gordon C. Wells (New York: Penguin Books, 2002).

${ }^{25}$ John P. McCormick, "Political Theory and Political Theology: The Second Wave of Carl Schmitt in English," Political Theory 26, no. 6 (1998). pp. 831-835; Schmitt's great fear of Soviet Russia becomes a common theme in his subsequent writings. Consider for example the passage "We in Central Europe live under the eyes of the Russians. For a century their psychological gaze has seen through our great words and institutions. Their vitality is strong enough to seize our knowledge and technology as weapons. Their prowess in rationalism and its opposite, as well as their potential for good and evil in orthodoxy is overwhelming. They have realized the union of Socialism and Slavism, which already in 1848 Dononso Cortes said would be the decisive event of the next century." Schmitt, "The Age of Neutralizations and Depoliticizations." p. 130 
the political belongs the idea, because there is no politics without authority and no authority without an ethos of belief., 26 Thus, many commentators have sought to portray Schmitt's political writings as being laced with theological motivations that have never left him. ${ }^{27}$ Heinrich Meier goes so far at to claim that, "Schmitt embarks upon his confrontation with liberalism in the name of the political, and he pursues it for the sake of religion. ${ }^{28}$ Miguel Vatter, for example, refers to Schmitt's formulation of the political as a "postmodern orthodoxy or fundamentalism." Vatter sees Schmitt's emphasis on the absolute nature of political distinctions as a way of bringing out a "religious and supracultural ground for authentic identity." 29 Equally, Schmitt's later claim that, "All significant concepts of the modern theory of the state are secularized theological concepts..." has been pointed to as evidence of his attempts to delegitimize modernity's conceptual independence from preceding historical periods. ${ }^{30}$ Nevertheless, these

\footnotetext{
${ }^{26}$ Schmitt, Roman Catholicism and Political Form. p. 17 My emphasis

${ }^{27}$ One of the most well known works in this area is that of the German Straussian scholar Heinrich Meier who argues that Schmitt's political theory is deeply embedded in a theological worldview. See Meier, Carl Schmitt \& Leo Strauss: The Hidden Dialogue. and Meier, The Lesson of Carl Schmitt: Four Chapters on the Distinction between Political Theology and Political Philosophy.; See as well Andrew Norris, "Carl Schmitt's Political Metaphysics: On the Secularization of the 'Outermost Sphere'," Theory \& Event 4, no. 1 (2000).; McCormick, "Political Theory and Political Theology: The Second Wave of Carl Schmitt in English." pp. 831-835; Likewise, in Lilla, "The Enemy of Liberalism." who writes that "His romanticizing of catholic institutions, his praise of Mussolini, his attempts to salvage democratic legitimacy from the legalism of the Weimar system, and his work for Hitler while not consistent, reflect a willingness to encourage any force that might do battle against the secularized liberal age. He describes himself repeatedly as a katechon, the Greek term that Saint Paul uses when speaking of the force that holds off the anti-Christ until the second coming (2 Thessalonians 2:6). As for his speculations about a new "nomos of the earth", they reflect nothing so much as the messianic longings of an aging apocalyptic thinker." p. 44

${ }^{28}$ Meier, Carl Schmitt \& Leo Strauss: The Hidden Dialogue. p. 30

${ }^{29}$ Miguel Vatter, "Politics as War: A Formula for Radical Democracy," Multitudes, no. 9 (2002).

${ }^{30}$ Carl Schmitt, Political Theology: Four Chapters on the Concept of Sovereignty (Cambridge: MIT Press, 1985). p. 36; For example, the state of an exception in jurisprudence, residing outside an immanent legalism, would be analogous to a self-referent miracle. Or that of the omnipotent lawgiver in the JudeoChristian tradition transforms itself through secularization into the Hobbesian "mortal god" with absolute power. Blumenberg has strongly contested this secularization claim. Blumenberg argues that "From this point of view it is certainly correct to say that an emphasis on limiting cases and exceptional situation insists on a function of the state that must take as its point of departure the failure of the Enlightenment; but
} 
theological considerations will even become templates for interpreting Schmitt's writings on international law and order. ${ }^{31}$ However, while the theological ground of Schmitt's thought has been used to derive a set of conclusive answers posed by Schmitt's own diagnosis of the modern age and the political, an often-neglected fact of Schmitt's life was that he was excommunicated from the Catholic Church in 1926 until 1950 for remarrying without its explicit approval. ${ }^{32}$

Nonetheless, his early publications until around 1938, with his fall from grace within the Nazi government, lay in the realm of constitutional law and jurisprudence. With the exception of his 1927 The Concept of the Political, Schmitt's emphasis then was on understanding a proper conceptual foundation for the maintenance of legal norms. In contrast who at the time was the predominant tradition of legal positivism, embodied in

that need not necessarily mean that it has to go back to the species of concepts that preceded the enlightenment and repeat that species in its 'secularized' form. It seems to me, then, that what lies behind the proposition that the significant concepts of the modern doctrine of the state are secularized theological concepts is not so much a historical insight, as Cart Schmitt asserts when he explains that these concepts were 'transferred from theology to political theory,' as it is a dualistic typology." Hans Blumenberg, The Legitimacy of the Modern Age (Cambridge: MIT Press, 1983). p. 92; Schmitt's reply to Blumenberg's attack came in the as of yet untranslated Political Theology II. Carl Schmitt, Politische Theologie I I. Die Legende Von Der Erledigung Jeder Politischen Theologie (Berlin,: Duncker u. Humblot, 1970).; See JanWerner Müller's discussion on the Blumenberg Schmitt debate in Müller, A Dangerous Mind: Carl Schmitt in Post-War European Thought. pp. 157-168; For a discussion on the conceptual formulation of political theology in the early Middle Ages, see the classic text by Ernst Kantorowicz. Kantorowicz discusses the relationship between the "mystical" body and original theological conceptions of sovereignty. Ernst Hartwig Kantorowicz, The King's Two Bodies: A Study in Mediaeval Political Theology (Princeton: Princeton University Press, 1957). For the above text's relationship with Schmitt see Agamben, Homo Sacer: Sovereign Power and Bare Life. pp. 92-94

${ }^{31}$ Martii Koskenniemi, "International Law as Political Theology: How to Read Nomos Der Erde?," Constellations 11, no. 4 (2004), Meier, The Lesson of Carl Schmitt: Four Chapters on the Distinction between Political Theology and Political Philosophy. Chapter 4; Others, for examples have argued that Schmitt's conception of international law and order is actually grounded in a paganism that rejects the very principles of Judeo-Christian universalism. Wolfgang Palaver, "Carl Schmitt on Nomos and Space," Telos, no. 106 (1996). These issues will be discussed in more detail in the next chapter.

${ }^{32}$ Balakrishnan, The Enemy: An Intellectual Portrait of Carl Schmitt. p. 62 Indeed, Balakrishnan writes that "The open break [with the Catholic Church] would not come until later, but even before this happened Schmitt would already have rejected two of the central ideas put forward in Römisher Katholizismus und politische Form. The first was the idea that the secular state and the church should be joined in a partnership in which the former had direct power and the latter had indirect authority... The second idea which Schmitt would come to reject was the idea of an authority claiming universal jurisdiction.” pp. 63-64 
such figures as Hans Kelsen, Hermann Heller, and Hugo Krabbe (who also found a sociological legitimacy in Max Weber), Schmitt's desire was to demonstrate the fallacy of conceiving of a legal order that properly adjudicates every legal conflict and thus remains impermeable. ${ }^{33}$ By contrast, Schmitt argues that a personal and necessarily absolutist decision maker is necessary to resolve legally indeterminate situations. As Schmitt writes:

It is not the command as command, but the authority or the sovereignty of an ultimate decision given in command, which constitutes the source of all law, that is, of all the norms and all the orders that follow from it...Consequently the sovereign decision can be juridically explained neither from a norm nor by a concrete order because for decisionism it is the decision that grounds both the norm and the order. The sovereign decision is an absolute beginning, and the beginning is nothing else than a sovereign decision. It springs out of nothingness and from concrete disorder. ${ }^{34}$

The above passage clearly illustrates what many commentators have termed as a decisionism that is reliant upon a subject will. It is this form of decisionism that will form the core of Schmitt's construction of the concept of sovereignty and later his own notions of the political and global order.

\footnotetext{
${ }^{33}$ For example Max Weber wrote that "Present day legal science, at least in the forms which have achieved the highest measure of methodological and logical rationality, i.e. those which have been produced through the legal science of the Pandectist's Civil Law, proceeds from the following five postulates: viz. first, that every concrete legal decision be the 'application' of an abstract legal proposition to a concrete 'fact situation'; second, that it must be possible in every concrete case to derive the decision from abstract legal propositions by means of legal logic; third, that the law must actually or virtually constitute a 'gapless' system of legal propositions or must at least be treated as if it were such a gapless system; fourth, that whatever cannot be 'construed' rationally in legal terms is also legally irrelevant; and fifth, that every social action of human beings must also be visualized either as 'application' or 'execution' of legal propositions or as an infringement thereof, since the 'gaplessness' of the legal system must result in the gapless legal ordering of all social relations." Quoted from Ibid. p. 45 and taken from Max Weber, Economy and Society (Berkeley: University of California Press, 1978). p. 657; For a study of the relationship between Schmitt and other legal theorists of the Weimar republic see David Dyzenhaus, Legality and Legitimacy: Carl Schmitt, Hans Kelsen and Hermann Heller in Weimar (Oxford: Claredon Press, 1997). For a critique of the above mentioned work see Paul Piccone and Ulmen Gary, "Uses and Abuses of Carl Schmitt," Telos Winter 2002 (2002). p. 21-22

${ }^{34}$ Quoted from Andreas Kalyvas, "From the Act to the Decision: Hannah Arendt and the Question of Decisionism," Political Theory 32, no. 3 (2004). pp. 322-323 In this article Kalyvas draws a connection between Schmitt's decisionism and Arendt's conceptualization of action through what he calls the "event of the miracle."
} 
In 1922 Schmitt published Political Theology: Four Chapters on the Concept of Sovereignty, which had the purpose of clarifying the concept of sovereignty. Schmitt's point of departure was to deploy a conception of "sovereignty" that originated in Bodin and in Hobbes and to extend it to a singular moment of decision: "Sovereign is he who decides on the exception"(Souverän ist, wer über den Ausnahmezustand entscheidet). ${ }^{35}$ Sovereignty, what Schmitt calls a "borderline concept" then situates itself at the "outermost sphere", is a topological conceptualization denoting the inherent limit of a normal juridical order in the face of an exterior emergency that cannot be codified in any legal order, and yet is latent within any. Schmitt clarifies: "Although [the sovereign] stands outside the normally valid legal system, he nevertheless belongs to it, for it is he who must decide whether the constitution needs to be suspended in its entirety." ${ }^{36}$ The role of the sovereign is first and foremost to decide when to suspend the legal order in the face of an emergency. ${ }^{37}$ The state of exception, however, can occur when the state itself is existentially threatened either through civil war or through an external crisis. Thus, the comportment of the sovereign cannot be formally codified through a set of norms. Sovereignty thus remains within, as Giorgio Agamben notes, a "zone of indistinction" between the inside of the legal order and its exterior domain (where norms lose their

${ }^{35}$ Schmitt, Political Theology: Four Chapters on the Concept of Sovereignty. p. 5; Carl Schmitt, La Dictature, L'ordre Philosophique; (Paris: Éditions du Seuil, 2000). pp. 42-55

${ }^{36}$ Schmitt, Political Theology: Four Chapters on the Concept of Sovereignty. p. 7

${ }^{37}$ Agamben, State of Exception. Agamben writes that "In truth, the state of exception is neither external nor internal to the juridical order, and the problem of defining it concerns precisely a threshold, or a zone of indifference, where inside and outside do not exclude each other rather blur with each other. The suspension of the norm does not mean its abolition, and the zone of anomie that it establishes is not (or at least claims not to be) unrelated to the juridical order." p. 23 
validity). This zone necessitates a decision-maker who will determine, "what constitutes public order and security, in determining when they are disturbed, and so on."38 Here, Schmitt's positing of the sovereign intersects with Thomas Hobbes' own formulation. Hobbes' solution of casting away the domestic state of nature is contingent upon a public absolutism of authority endowed in the will of the sovereign. A covenant allows granting the sovereign the ability to make autonomous decisions whereby it

.... is annexed to the sovereign the right of judicature, that is to say, of hearing and deciding all controversies which may arise concerning law (either civil or natural) or concerning fact. For without the decision of controversies there is no protection of one subject against the injuries of another, the laws concerning meum and tuum are in vain, and to every man remaineth from the natural and necessary appetite of his own conversation, the right of protecting himself by his private strength, which is the condition of war, and contrary to the end for which every commonwealth is instituted. ${ }^{39}$

The decisions enacted by the sovereign must be obeyed because of their contractual obligation that assures the subjects of the sovereign protection from internal and external threats. Hobbes was not so much interested in the substance of the particular legal or political configuration of the state as he was interested in what was the constituent power of the polity. As Reinhardt Koselleck argues, "Their legality [of the laws of the polity] did not lie in their substantive qualification but in their source alone, in the fact that they expressed the will of the sovereign power.

\footnotetext{
${ }^{38}$ Schmitt, Political Theology: Four Chapters on the Concept of Sovereignty. p. 9; Agamben, State of Exception. p. 23

${ }^{39}$ Thomas Hobbes, Leviathan : With Selected Variants from the Latin Edition of 1668 , ed. E. M. Curley (Indianapolis: Hackett Pub. Co., 1994). Chapter xvii [11] p. 114; See as well Sheldon Wolin's treatment of Hobbes in Sheldon S. Wolin, Politics and Vision: Continuity and Innovation in Western Political Thought, Expanded ed. (Princeton: Princeton University Press, 2004). Chapter 8

${ }^{40}$ Reinhart Koselleck, Critique and Crisis: Enlightenment and the Pathogenesis of Modern Society (Cambridge: MIT Press, 1988). p. 34
} 
Schmitt's motivation for conceiving of sovereignty as the moment of a concrete decision resides in the very possibility that legal recourse during times of crisis is ineffectual and that a solution cannot immanently lie within the given legal structure. ${ }^{41}$ Contextually, Schmitt's legal reasoning took place within what was the constitutional debate-surrounding article 48 of the Weimar constitution. ${ }^{42}$ It stipulated the ability of the president to suspend temporarily the constitution during times of emergency. The legal debate at the time was whether article 48 allowed for the total suspension of the constitution or only of certain articles. Schmitt's position was that the totality of the constitution, with the exception of the "identity of the institutions", was in principle subject to suspension during a state of exception. ${ }^{43}$ What is important to keep in mind, however, is that Schmitt's position was contingent upon an understanding of what properly constitutes a dictatorship. He distinguished between a commissarial dictatorship and a sovereign dictatorship. A commissarial dictatorship emerges when it, as Schwab explains,

(1) occurs at the moment when an established states of affairs is sufficiently threatened to warrant the appointment of a dictator, (2) the dictator is appointed by the sovereign - a pouvoir constitué - to accomplish a specific mission, and when it has been accomplished the dictators task ceases, (3) in order for the mission to be successful...the commissarial dictator may temporarily suspend or make extreme inroads into the constitution and the

\footnotetext{
${ }^{41}$ Schmitt, Political Theology: Four Chapters on the Concept of Sovereignty. p. 6

42 "Article 48 states: Section 2 If, in the German Reich, public security and order is considerably disturbed or endangered, the Reichspresident may undertake necessary measures in order to restore public security and order. For this purpose he may suspend, temporarily, in part or entirely, the basic rights as provided in Articles 114, 115, 117, 123, 124, and 153." Schwab, The Challenge of the Exception: An Introduction to the Political Ideas of Carl Schmitt between 1921 and 1936. p. 37

${ }^{43}$ Balakrishnan, The Enemy: An Intellectual Portrait of Carl Schmitt. p. 44; See as well Cristi, Carl Schmitt and Authoritarian Liberalism: Strong State, Free Economy. p. 8 who writes that ultimately "[Schmitt's] interpretation of the constitution bore political fruit. President Hidenburg installed a presidential regime, based on Schmitt's reading of article 48, which introduced an authoritarian system of government."
} 
domain of ordinary legislation, but he may not abrogate existing laws from the statute books. ${ }^{44}$

The commissarial dictatorship is similar to the Roman juridical custom of declaring a temporary dictator by enacting a senatus consultum ultimum during a period of extreme danger. ${ }^{45}$ On the other hand, the sovereign dictator, as Schmitt writes, "sees in the total existing order the situation which it seeks to do away with through its actions" where the goal is "to create a condition whereby a constitution will become possible." ${ }^{46}$ It should be noted as well that Schmitt's 1929 treatise on constitutional law, Verfassungslehre, confirms that Schmitt was not in Toto against the principles set within the Weimar constitution. ${ }^{47}$ These principles were the expression of the constituent power as embodied in the will of the German people. ${ }^{48}$

Conceptually, Schmitt argues that, to understand a given legal order, a proper understanding of the state of exception is necessary: "The rule proves nothing; the

${ }^{44}$ Schwab, The Challenge of the Exception: An Introduction to the Political Ideas of Carl Schmitt between 1921 and 1936.p. 32 my emphasis

${ }^{45}$ Agamben, State of Exception. p. 41

${ }^{46}$ Quoted from Schwab, The Challenge of the Exception: An Introduction to the Political Ideas of Carl Schmitt between 1921 and 1936. p. 35 Schmitt's distinction between the power that founds the constitution - pouvoir constituant - and the power that preserves the constitution is reminiscent of the dialectical movements between law-preservation and lawmaking in Walter Benjamin's Critique of Violence. However, while Benjamin sought to establish the possibility of a divine violence that "expiates" and where "Justice is the principle of all divine end making...", Schmitt's goal was to ground sovereign violence as a decision on the suspension of the legal order. Hence, as Agamben notes, Schmitt's Political Theology can be construed as a response to Benjamin's divine or pure violence where Schmitt's attempt is to "neutralize pure violence and ensure the relation between anomie and the juridical context." Walter Benjamin, "Critique of Violence," in Reflections: Essays, Aphorisms, Autobiographical Writings, ed. Peter Demetz (New York: Schocken Books, 1989). p. 295 and Agamben, State of Exception. p. 54; For an interesting discussion on the relationship between Schmitt and Benjamin, see Horst Bredekamp, "From Walter Benjamin to Carl Schmitt, Via Thomas Hobbes," Critical Inquiry 25, no. Winter (1999).; Likewise on the relationship of Schmitt and Benjamin through their reading of George Sorel and the role of violence, see Jan-Werner Müller, "Myth, Law and Order: Schmitt and Benjamin Read Reflections of Violence," History of European Ideas 29 (2003).

47 Carlo Galli, "The Critic of Liberalism: Carl Schmitt's Antiliberalism: Its Theoretical and Historical Sources and Its Philosophical and Political Meaning," Cardozo Law Review 21, no. 1597 (2000).

${ }^{48}$ Carl Schmitt, Verfassungslehre, 8. Aufl. ed. (Berlin: Duncker \& Humblot, 1993). pp. 162-163 
exception proves everything: it confirms not only the rule but also its existence, which derives only from the exception. In the exception the power of real life breaks through the crust of a mechanism that has become torpid by repetition."49 The set of norms that characterize a given order must necessarily rely upon a normal state of affairs in order to function properly. By its very nature, "there exists no norm that is applicable to chaos." Following counter-revolutionary writers such as de Maistre, Dononso Cortes, and Louis de Bonald who argued for the infallibility of the absolute sovereign in the face of political contingency along Hobbesian lines, Schmitt argues that this necessarily implies that "all law is "situational law'." 51 Schmitt thus refuses to conflate the legal structure of society with that of the state. The state remains above society as the ultima ratio to guarantee a properly functioning society that gives meaning to legal norms. Schmitt asserts the necessity of maintaining this Hobbesian hierarchical relationship because of the state's necessity in acting as a neutral third-party to resolve internal political disputes. In particular, Schmitt takes here aim at the neo-Kantian legal formalism of Hans Kelsen and Hugo Krabbe that banish the state of exception and arrive at a purely juristic notion of the

\footnotetext{
${ }^{49}$ Schmitt, Political Theology: Four Chapters on the Concept of Sovereignty. p. 15; For example, Arendt describes how the Nazi use various different categories of Jews allowed for the possibilities of petitioning for exceptions from deportation to the east. Whereby these "exceptions" confirm the general rule of deportation and genocide. Hannah Arendt, Eichmann in Jerusalem : A Report on the Banality of Evil (New York: Penguin Books, 1994). p. I32

${ }^{50}$ Schmitt, Political Theology: Four Chapters on the Concept of Sovereignty. p.13

51 Ibid.; Schmitt's appropriation of de Maistre's thought has recently been contested by Owen Bradley's work. Bradley writes that "Schmitt portrays Maistre as an extreme Augustinian, urging the absolute and unmotivated divine decisions of creation and salvation, and not the Origenist, defending both an infinite plurality of spiritual powers apocatastasis, that is, the complete gradual solution of cosmic conflict by the reformulation of wills, not by an apocalyptic absolutist intervention." Bradley continues by calling Schmitt's interpretation of de Maistre "hackneyed" and interprets Schmitt's absolute sovereign as a "jackin-the-box hidden Gnostic." Owen Bradley, A Modern Maistre: The Social and Political Thought of Joseph De Maistre (Lincoln: University of Nebraska Press, 1999). p. 123-126; Likewise for an in depth introduction to the ideas of Dononso Cortez and the his relationship with Schmitt see Jeffery Johnson's introduction in Donoso Cortes, Selected Works of Juan Donoso Cortes.
} 
state. ${ }^{52}$ It is precisely this state of exception that removes the "veil of ignorance" over the nature of sovereign power within a given political structure during normal times and exposes a uniform political will that is able to make a concrete "decision ex nihilo". 53

Schmitt describes the act of decision as "a pure decision not based on reason and discussion and not justifying itself, that is,... an absolute decision created out of nothingness." ${ }^{, 54}$ Whereas Max Weber continued to speak of an "ethics of responsibility" as a way grounding political decisions in his Politics as a Vocation, Schmitt waves away any ethical or moral restriction. ${ }^{55}$ The motivation is thus to disabuse people from a reliance on legal formalism in times if crisis. As Schmitt notes, “...all legitimate and normative illusions with which men like to deceive themselves regarding political realities in periods of untroubled security vanish." ${ }^{, 56}$ Hence, the necessity of relying on the concrete political actions of a personalized sovereign in order to restore a normal state of affairs.

Such a conception of sovereignty and of the absolute decisionism thus displayed is diametrically opposed to the traditional liberal principle of equality under the "rule of law." Richard Wolin, for example, argues that Schmitt in fact aestheticizes the role of the sovereign as a polemic against the everyday "normalcy" of modern bourgeois liberalism.

\footnotetext{
${ }^{52}$ Schmitt, Political Theology: Four Chapters on the Concept of Sovereignty. p. 18

53 Eckard Bolsinger, The Autonomy of the Political: Carl Schmitt's and Lenin's Political Realism (Westport: Greenwood Press, 2001). pp. 26-27

${ }^{54}$ Schmitt, Political Theology: Four Chapters on the Concept of Sovereignty. p. 66

${ }^{55}$ Max Weber, From Max Weber: Essays in Sociology, ed. Hans Heinrich Gerth and C. Wright Mills, trans. Hans Heinrich Gerth and C. Wright Mills (New York: Oxford University Press, 1958). p. 120

${ }^{56}$ Schmitt, The Concept of the Political. p. 52; For the latest discussion on US National Emergency Powers see Harold C. Relyea, "National Emergency Powers," in 98-505 GOV (Congressional Research Service, 2001).
} 
For Wolin sees the emphasis on the concrete exception, as "only the will to power of 'real life' [that] possesses the capacity to break through the inertial character of society $q u a$ encrusted mechanism." ${ }^{, 57}$ Wolin's own quasi-Aristotelian critique, through his own concern with a retrieval of classical philosophical questions concerning the "good life" of man within the polis, originates in Karl Löwith's own critique. As Löwith noted:

What Schmitt defends is a politics of sovereign decision, but one in which content is merely a product of the accidental occasio of the political situation which happens to prevail at the moment; hence content is precisely not a product 'of the power of integral knowledge' about what is primordially correct and just, as it is in Plato's concept of the essence of politics, where such knowledge grounds an order of human affairs. ${ }^{58}$

Echoing Wolin, Jürgen Habermas even goes so far as to write that "for Carl Schmitt's polemical discussion of political Romanticism conceals the aestheticizing oscillations of his own political thought. In this respect, too, a kinship of spirit with the fascist intelligentsia reveals itself." 59 Emmanuel Tuchscherer also connects Schmitt to the prevailing Kriegsideologie of the interwar years and suggests that Schmitt "justified a

\footnotetext{
${ }^{57}$ Wolin, "Carl Schmitt: The Conservative Revolutionary Habitus and the Aesthetics of Horror." p. 434

${ }^{58}$ Löwith, "The Occasional Decisionism of Carl Schmitt." p. 144; For example Wolin writes "In pursuing the existentialist track, Schmitt consciously abandons all higher questions about the meaning of political life, questions he hastily equates with the normativist tradition he is so eager to be done with. The sole important fact is that the state exists, not the specific content or ends of its existence. In this respect, Löwith's critique proves justified: insofar as Schmitt's notion of the political is devoid of independent content, it, too, is a mere "occasionalism." See Richard Wolin, "Carl Schmitt, Political Existentialism, and the Total State," Theory and Society 19, no. 4 (1990). p. 407; Leo Strauss presents an argument for the devaluation of classical political philosophical concerns towards the modern political expediency displayed in Machiavelli and Hobbes: "Classical political science took its bearings by man's perfection or by how men ought to live, and it culminated in the description of the best political order. Such as order was meant to be one whose realization was possible without a miraculous or nonmiraculous change in human nature, but its realization was not considered probable, because it was though to depend of chance. Machiavelli attacks this view by demanding that one should takes one's bearing, not by how men ought to live but how they actually live, and by suggesting that chance could or should be controlled. It is the attack which laid the foundation for all specifically modern political thought. The concern with the guarantee for the realization of the "ideal" led to both a lowering of standards of political life and to the emergence of 'philosophy of history': even the modern opponents of Machiavelli could not restore the sober view of the classics regarding the relation of 'ideal' and 'reality"' Leo Strauss, On Tyranny, ed. Victor Gourevitch and Michael S. Roth, Rev. and expanded ed. (New York: Free Press, 1991). pp. 231 -232

${ }^{59}$ Habermas, "The Horrors of Autonomy: Carl Schmitt in English." p. 137
} 
Nazi politics of aggression during the second world war by developing and legitimizing a discourse of war at the start of the 1930s."60 While these criticism border on the polemical they miss the mark on what Schmitt is trying to articulate. As will subsequently be seen, Schmitt's concern was not the glorification of conflict for the sake of conflict, nor the exaltation of an absolute sovereign dictatorship - at least prior to 1933 with his latter justifications of Hitler's own abuses of power - as could be found in the writings of Ernst Jünger and other nationalist and fascist writers. Rather his main concern was in articulating a conception of what properly constitutes a concrete order. Schmitt's concern was then to reestablish a set of political concepts that, in the face of a degeneracy of the modern European state system, could bracket conflict instead of totalizing it. Yet, prior to understanding what constitutes a concrete order, it is necessary to understand how Schmitt conceives the essence of the political. Starting with the claim that "the concept of the state presupposes the concept of the political," Schmitt sought to distance a formulation of the political from the authoritative function of the state that he claims vanishes in liberal and Marxist theories of the state. ${ }^{61}$ The former reduce the political to a normative framework of legal principles, while the latter relegates the state to an economic functionality that eventually disappears with the advent of the classless society. Yet, only when a state has a "monopoly on politics" is the equation state = political valid. Only when the state retrieves the ability to decide on the exception and thus stands above the plurality of different parties within the polity can we conflate the political to the state.

\footnotetext{
${ }^{60}$ Emmanuel Tuchscherer, "Le Decisionnisme De Carl Schmitt: Theorie Et Rhetorique De La Guerre," Mots, no. 73 (2003). My Translation

${ }^{61}$ Schmitt, The Concept of the Political. p. 23
} 


\section{Schmitt writes:}

The equation state $=$ the political becomes erroneous and deceptive at exactly the moment when state and society penetrate each other. What had been up to that point affairs of state become thereby social matters, and, vice versa, what had been purely social matters become affairs of state - as must necessarily occur in a democratically organized unit. Heretofore, ostensibly neutral domains - religion, culture, education, the economy - then cease to be neutral in the sense that they do not pertain to be to state and to politics. As a polemical concept against such neutralizations and depoliticizations of important domains appears the total state, which potentially embraces every domain. This results in the identity of state and society. In such a state, therefore, everything is at least potentially political, and in referring to the state it is no longer possible to assert for it a specifically political characteristic. ${ }^{62}$

\section{Political Friends and Enemies}

Why does Schmitt use the term political instead of simply referring to politics? Whereas politics remains the domain of empirically observed power or social relations among differing actors, the political becomes a quasi-transcendental or metaphysical locus of inquiry into the polity or regime. An inquiry into the political, as the French political theorist Claude Lefort notes, becomes an inquiry into the very fabric of the "social space, of the form of society, of the essence of what was once termed the 'city'."63 While we continuously regard political activity as that which constitutes politics, the realm of the political remains, as Ernst Vollrath describes, "the sphere or realm of politics and the specific modality according to which we may speak of phenomena - events, persons, actions, institutions, etc, - as to their political quality."

\footnotetext{
62 Ibid. p. 22

${ }^{63}$ Claude Lefort, Democracy and Political Theory (Minneapolis: University of Minnesota Press, I988). p. 11

${ }^{64}$ Fred R. Dallmayr, The Other Heidegger, Contestations (Ithaca: Cornell University Press, 1993). p. 50
} 
Schmitt's The Concept of the Political is as such a conceptual inquiry into the political which constitutes the "order of the human things." 65 Here Schmitt orients himself closely to Hobbes whom he regards as being "truly a powerful and systematic political thinker..." Schmitt position's himself as well next to other classical political realist thinkers whose "realism can frighten men in need of security." ${ }^{.66}$ Fear of violent death became the basis of the Hobbes negation of the political through the emergence and power of the state over its subjects. ${ }^{67}$ Yet it should be recalled that Hobbes did interject an important qualification concerning the limits of what the sovereign may demand of the individual. Hobbes writes that:

Upon this ground a man is commanded as a soldier to fight against the enemy, though his sovereign have right enough to punish his refusal with death, may nevertheless in many way cases refuse without injustice...And there is allowance made to natural timorousness, not only to women (of whom no such dangerous duty is expected) but also to men of feminine courage...

Herein, however, lies an important difference between Hobbes and Schmitt. Hobbes recognizes that the sovereign's demand for the subject to risk life and limb is equivalent

\footnotetext{
${ }^{65}$ Schmitt, The Concept of the Political. p. 95

${ }^{66}$ Ibid. p. 65
}

${ }^{67}$ For example, Leo Strauss writes that "Fear is not only alarm and flight, but also distrust, suspicion, caution, care lest one fear. Now it is not death in itself that can be avoided, but only death by violence, which is the greatest of possible evils. For life can be such misery that death comes to be ranked with the good. In the final instance, what is of primary concern is ensuring the continuance of life in the sense of ensuring defense against other men. Concern with self-protection is the fundamental consideration, the one most fully in accord with the human situation. This is the origin of the distinction between (moral) good and (moral) evil. The fear of death, the fear of death by violence, is the source of all right, the primary basis of natural right." My emphasis. Leo Strauss, Spinoza's Critique of Religion (New York,: Schocken Books, 1965). p. 93; The above passage begins to articulate a familiar theme regarding the transition from sovereign power to bio-political power that is seen beginning with Hobbes and latter Spinoza as they describe the role of the state founded towards the maintenance of life. This issue of the bio-political is then theorized in Arendt's The Human Condition concerning the "rise of the social" and the subsuming of the public space towards the basics needs of life. The bio-political theme is explored in more detail with Michel Foucault and with Giorgio Agamben. See Arendt, The Human Condition. Michel Foucault, The History of Sexuality, V.1 vols. (New York: Vintage Books, 1988). Part 5; See as well, Miguel Vatter, "Strauss and Schmitt as Readers of Hobbes and Spinoza," The New Centennial Review 4, no. 3 (2004).

${ }^{68}$ Hobbes, Leviathan: With Selected Variants from the Latin Edition of 1668. p. 152-I53 
to a return to the state of nature. Schmitt argues instead "In case of need, the political entity must demand the sacrifice of life." 69 The liberal premise of "individualism" or autonomy precludes the possibility of demanding such sacrifice in the interest of the state. In which case, Schmitt writes, "We arrive at an entire system of demilitarized and depoliticized concepts...the political concept of battle in liberal thought becomes competition in the domain of economics and discussion in the intellectual realm." 70

Still, Schmitt is consistent in his desire to disabuse the liberal conception of the political that enables for a neutral or progressive perception of human nature whereas traditionally "all genuine political theories presuppose man to be evil."71 One can already see this in later Enlightenment thinkers, such as Condorcet and Turgot, who argued for the very possibility of human perfection. ${ }^{72}$ This continued perfectibility is in part guided by a greater emphasis on human reason necessary to be able to transcend historical and political contingency. Science and technology become the blueprints for an everperfectible peaceful society. Accordingly, technology once again becomes the neutral ground that can decide the various political issues between social groups. However, Schmitt's point of departure remains that man at his core is a homo hominis lupus. In this case, the state of nature as the stare of war remains the constitutive potentiality for all social relations. "There always are concrete human groupings which fight other concrete

\footnotetext{
${ }^{69}$ Schmitt, The Concept of the Political.p. 71

${ }^{70}$ Ibid.

${ }^{71}$ Ibid. p. 61 My emphasis

${ }^{72}$ Karl Löwith, Meaning in History (Chicago: University of Chicago Press, 1957). pp. 92-93
} 
human groups in the name of justice, humanity, order, or peace." ${ }^{\prime 73}$ As will be seen, this ontological assumption of the continuous and latent state of war characterizes Schmitt's attempts to reaffirm the political in the face of continuous attempts by liberalism to heighten the neutralization and depoliticization of the state through a subjection of the political to the rule of law. Thus, the inconsistency within liberalism is precisely its lack of ability to connect principle of mitigating the political confrontation through the rule of law with the problematic of the state of exception. The state of exception as a state of war where "there is no norm applicable to chaos" is precisely the singular point where the liberal logic breaks down.

In any case, Schmitt begins his analysis of the political by describing the political as an autonomous category distinct from other social forms. ${ }^{74} \mathrm{He}$ compares it with the explicit dichotomies found in morality, economics, and aesthetics. While the moral has an intrinsic dichotomy between good and evil; the economic between, profitable and unprofitable; and the aesthetic, between beautiful and ugly, the political has as its fundamental distinction, a pre-cultural and existential conception of "friend" versus "enemy.", to that of a competitor as in economics. In other words, an "...enemy exists only when, at least potentially, one fighting collectivity of people confronts a similar collectivity." Given the real possibility of armed conflict, the enemy represents a threat to the way of

\footnotetext{
${ }^{73}$ Schmitt, The Concept of the Political.p. 67

${ }^{74}$ Ibid. p. 26

${ }^{75}$ Ibid. pp. 26-27

${ }^{76}$ Ibid. p. 28
} 
life of the community. Thus the political remains a domain of "the most intense and extreme antagonism" between a constellation of possible groupings, where "nothing can escape this logical conclusion of the political." ${ }^{, 77}$ As in Political Theology, Schmitt emphasizes the boundary conditions or limit cases to uncover what can properly be called the political. What is important to note here is that Schmitt does not focus on who is the enemy per se but rather on the ability to make this distinction. This distinction however "denotes the utmost degree of intensity of a union or separation, of an association or disassociation." 78 For Schmitt, then, "the high points of politics are simultaneously the moments in which the enemy is, in concrete clarity, recognized as enemy.",79 The enemy is simply, "the stranger; and it is sufficient for his nature that he is, in a special intense way, existentially something different and alien, so that in the extreme case conflicts with him are possible." ${ }^{80}$ Nothing, however, compels that the friend-enemy grouping remain a fixed arrangement. On the contrary, Schmitt articulates it as an ever-changing possibility contingent upon concrete present political exigencies. Today's enemy can nonetheless become tomorrow's friend. ${ }^{81}$ "The political enemy need not be morally evil or aesthetically ugly; he need not appear as an economic competitor, and it may even be advantageous to engage with him in business transaction." 82

\footnotetext{
${ }^{77}$ Ibid. pp. 29, 33, 36

${ }^{78}$ Ibid. p. 26

${ }^{79}$ Ibid. p. 67

${ }^{80}$ Ibid. p. 27

${ }^{81}$ Ibid. p. 35

82 Ibid. p. 27 my emphasis
} 
However, the boundary condition of the political also revolves around the intensity of confrontation between different social groupings. ${ }^{83}$ As Schmitt writes:

The political can derive its energy from the most varied human endeavors, from the religious, economic, moral, and other antithesis. It does not describe its own substance, but only the intensity of an association or dissociation of human beings whose motives can be religious, national (in the ethnic or cultural sense), economic, or of another kind and can effect at different times different coalitions and separations. The real friendenemy grouping is existentially so strong and decisive that the nonpolitical antithesis, at precisely the moment at which it becomes political, pushes aside and subordinates its hitherto purely religious, purely economic, purely cultural and motives to the conditions and conclusions of the political situation at hand. In any event, that grouping is always political which orients itself toward this most extreme possibility. This grouping is therefore always the decisive human grouping, the political entity. If such an entity exists at all, it is always the decisive entity, and it is sovereign in the sense that the decision about the critical situation, even if it is the exception, must always necessarily reside there. ${ }^{84}$

Here we see the importance of understanding Schmitt's conception of sovereignty as a decision on the exception. The exceptional situation, whereby the confrontation between enemies arrive at the possibility of "real physical killing", necessitates the ability of a sovereign to determine and manage such a situation. Schmitt insists that:

To the state as an essentially political entity belongs the jus belli i.e. the real possibility of deciding in a concrete situation upon the enemy and the ability to fight him with the power emanating from the entity. ${ }^{85}$

The actual decision as to whether or not to pursue armed conflict is the archetypal political decision that a sovereign makes. Thus, it is important not confuse Schmitt's conception of the political as inherently linked to the domain of military science or with

${ }^{83}$ There is a matter of controversy regarding this question of intensity in Schmitt's The Concept of the Political. Morgenthau claimed that Schmitt plagiarized this from his doctoral dissertation. See Scheuerman, Carl Schmitt: The End of Law. pp. 225-226, 231-237; On the other hand see Bendersky's response that the model of intensity has been present since the original publication of The Concept of the Political in 1927. Joseph W. Bendersky, "The Definite and the Dubious: Carl Schmitt's Influence on Conservative Political and Legal Theory in the Us.," Telos Winter 2002 (2002). p. 44

${ }^{84} \mathrm{Schmitt}$, The Concept of the Political. p. 38 my emphasis

${ }^{85}$ Ibid. p. 45 
the technical issues of war fighting: "As long as a politically united people is prepared to fight for its existence, independence, and freedom on the basis of a decision emanating from the political entity this political question has primacy over the technical means..."86 Nor is it valid to associate it with Clausewitz's notion that war is politics by other means. Rather, Schmitt inverts the Clausewitzian formula to precisely characterize the pre-legal setting that necessitates a unitary political will embodied in the state. ${ }^{87}$ The commonality of a group of individuals around a "way of life" is ultimately contingent upon this concrete ability to make political decisions that place the self-preservation of the group at stake in the face of future friend / enemy groupings. As Andrew Norris notes, "what is distinctively political, then, is entirely a matter of conflict with the enemy; the relation with the friend only a pretext for this conflict." ${ }^{, 88}$ Schmitt's quasi-Hobbesian conception of the political is conditional upon the definability of an "other". By contrast, Hannah Arendt sought to redefine a concept of the political that was not necessarily reliant upon an exclusion of an "other". An interesting comparison can be made between Arendt and Schmitt because they were both concerned with the modern liberal appeals to devalue the concept of the political to a form of administration. They both desired to reestablish an autonomous concept of the political in the face of a depoliticized world. Though Arendt

\footnotetext{
${ }^{86}$ Ibid. p. 46

${ }^{87}$ Ibid. p. 34; Michel Foucault likewise discusses the inversion of the Clausewitzian formula as a way of arriving at a pre-legal setting in order to understand what has come to be considered legitimate forms of authority, power, and ultimately domination in modern society. See Michel Foucault, Society Must Be Defended : Lectures at the Collège De France, 1975-76, ed. Mauro Bertani, Alessandro Fontana, and François Ewald, trans. David Macey (New York: Picador, 2003). pp. 15-19; For a discussion of the relationship between Foucault and Clausewitz see Julian Reid, "Foucault on Clausewitz: Conceptualizing the Relationship between War and Power," Alternatives 28 (2003).
}

${ }^{88}$ Andrew Norris, "Carl Schmitt on Friends, Enemies and the Political," Telos, no. 112 (1998). p. 70 
referred to Schmitt as a "convinced Nazi", both approach a concept of the political that is rooted in the genuinely free action of a groundless will. ${ }^{89}$

VI Excursus: Arendt and the Political

Hannah Arendt, like Schmitt, focuses her phenomenological analysis of the political by the reassertion of an autonomous and agonistic public space. Arendt's conception of virtù in fact, places her quite close to Machiavelli and Nietzsche with her because of this concept's glorification of collective political action. ${ }^{90}$ Yet it is in term of her investigation of political judgment that Arendt sought to "tame the agon" and provide the basis for a political theory that does not necessarily appeal to a singular political authority that is contingent upon an external enemy. ${ }^{91}$

The tripartite distinction in The Human Condition between action, labor, and work establishes the basis for this reinvestigation of the public space. By elevating action, or what she terms the vita activa, Arendt uses a performative model as a guide to describe the agonistic properties of authentic action. Arendt begins by retrieving an Aristotelian distinction between praxis and poiesis. Aristotle clarifies the distinction between the two by insisting that:

Everyone who makes (poiesis) anything makes it for some purpose, and the product is not an end in itself but only a relative or particular end. But an action (praxis) is an end itself, because good action is an end, and the object of appetition. ${ }^{92}$

\footnotetext{
${ }^{89}$ Hannah Arendt, The Origins of Totalitarianism (New York: Harcourt, 1994). p. 339; See also Kalyvas, "From the Act to the Decision: Hannah Arendt and the Question of Decisionism." p. 322

${ }^{90}$ Hannah Arendt, "What Is Authority?," in Between Past and Future : Eight Exercises in Political Thought (New York: Penguin Books, 1977). pp. 136-139; Villa, Arendt and Heidegger: The Fate of the Political. See Chapter 3; Villa, Politics, Philosophy, Terror: Essays on the Thought of Hannah Arendt. pp. 107-127

${ }^{91}$ Hannah Arendt, "The Crisis in Culture," in Between Past and Future : Eight Exercises in Political Thought (New York: Penguin Books, 1977).pp. 197-226

92 Aristotle, Ethics, trans. J. A. K. Thomson (New York: Penguin Books, 1976). p. 206 Here appetition
} 
Arendt's view is that the realm of the political is primarily the domain of praxis, where action must be understood as the striving for excellence in and of itself. ${ }^{93}$ This notion of praxis can be illustrated by the metaphor of the theatrical performance. This notion of a theatrical drama, drama coming from the Attic Greek dran (to act or perform), relies on a mimeses (imitation) of an observed act that Arendt argues comes alive in meaning only when it performed in the public theatre. ${ }^{94}$ Historically, the linkage between theatrical metaphors and the political can often can be observed as Arendt demonstrates, for instance, in her etymological inquiry of the word persona. Persona is the Latin word signifying the "mask affixed to an actor's face by the exigencies of the play." It later came to signify the "part he was expected to play on the public scene." 95 Interestingly, while Schmitt decried the aestheticization of political life by the romantics as necessarily leading to an "occasional" and by implication "unserious" and "entertaining" conception of the political, Arendt, by contrast, celebrates this theatrical aspect as the genesis of virtuosity in all public life. Theatricality - with its emphasis on the performative qua action - implies a non-teleological condition. In other words, the performance in and of itself, rather than a particular end, takes a primordial role in this conception of the political. In essence, what Arendt is seeking to uncover is a notion of human freedom with regards to the ability to act in public - that is not submerged by metaphysics. In this regard, Dana Villa points out that Arendt takes after Montesquieu's formulation of

\footnotetext{
means a desire or longing for.

${ }^{93}$ Arendt, The Human Condition. p. 206

94 Ibid. p. 187

${ }^{95}$ Hannah Arendt, On Revolution (Westport: Greenwood Press, 1982). pp. 106-107
} 
political principles that inspire different forms of governments but that do not prescribe specific political actions. ${ }^{96}$

Though Arendt was initially focused on retrieving a Hellenic conception of nonteleological action, she later became concerned with the problem of thinking and its implication for political judgment in modern society. Arendt took as the basis for a sound political public sphere the necessity of reflective judgment first put forth by Kant in his Critique of Judgment. She took this Kantian formulation of reflective judgments judgments that are not based on existing universal rules or norms - as a starting point for developing a political theory that reemphasizes the primacy of plurality and doxatic (from the Greek doxa or opinion) interaction. Given her emphasis on the predominance of the world of appearances in the political, it became natural for her to utilize reflexive judgments given their sole purpose of determining the aesthetic pleasure of speech-acts and of fostering an "enlarged mentality that enables men to judge."97 This ability, as Arendt noted, allows one "to think with an enlarged mentality means that one trains one's imagination to go visiting." 98 By appropriating the Kantian notion of reflexive judgments as disinterested, Arendt sought to transcend the political, as defined by Schmitt, as the distinction of friend and enemy associated with action while precluding ideologies of necessity. ${ }^{99}$ Likewise, by cultivating an ethos of sensus communis (common sense) within

\footnotetext{
${ }^{96}$ Villa, Politics, Philosophy, Terror: Essays on the Thought of Hannah Arendt. p. 139

${ }^{97}$ Hannah Arendt, "Truth and Politics," in Between Past and Future : Eight Exercises in Political Thought (New York: Penguin Books, 1977). p. 241

${ }^{98}$ Gisela T. Kaplan and Clive S. Kessler, Hannah Arendt : Thinking, Judging, Freedom (Boston: Allen \& Unwin, 1989). p. 56

${ }^{99}$ Villa, Arendt and Heidegger: The Fate of the Political. p. 104
} 
the public space, the emphasis was placed by Arendt on a competitive spirit between political actors who thus further the potentiality of human freedom seen in action.

However, Arendt's focus on the performative nature of the political, in fact, places her quite close to Schmitt's own form of decisionism. For Arendt, the essence of the political and by consequence human freedom is related to the spontaneous possibilities beginning something new. ${ }^{100}$ This spontaneous beginning of political action is associated with a groundless or "miraculous" deed that transcends the "commonly accepted" and where "everyday life no longer applies." 101 Arendt writes:

Every act, seen from the perspective not of the agent but of the process in whose framework it occurs and whose automatism it interrupts, is a 'miracle' - that is, something which could not expected. ${ }^{102}$

But this notion of the "unexpected" or miraculous action is indeed very similar to Schmitt's own concept of a decision on the state of exception. Both Arendt and Schmitt agree that for any political action to be considered pure or autonomous, it must be independent of a set of established norms.

However, it is also important to note that Arendt's political theory is set entirely inside the walls of the polis. The boundlessness of action, necessarily non-violent, comes to an end past the walls of the polis: "Outside the walls of the polis, that is, outside the realm of politics in the Greek sense of the word, "the strong did what they could and the weak did as they must.' (Thucydides)" ${ }^{\prime 103}$ In this case, Arendt's conception of the political

\footnotetext{
${ }^{100}$ Hannah Arendt, "What Is Freedom?," in Between Past and Future : Eight Exercises in Political Thought (New York: Penguin Books, 1977). p. 165

${ }^{101}$ Arendt, The Human Condition. p. 205

${ }^{102}$ Arendt, "What Is Freedom?." p. 169 my emphasis
} 
remains incomplete relative to the importance of inter-state relations and how these may ultimately affects the internal constitution of the polis. The contrast between Schmitt and Arendt is precisely where they situate the political. The political for Schmitt is always positioned relative to the foreigner and, concurrently, to the real possibility of war: "The political entity presupposes the real existence of an enemy and therefore coexistence with another political entity." 104 While on the other hand, for Arendt, attempts to found the political community on the "commonality of an enemy", such as in Rousseau's The Social Contract and his construction of the general will, necessarily results in an internal politics of terror against those groups that are not considered part of la nation une et indivisible. $^{105}$

V The Political and its Limits

If the political as the result of escalating confrontations in intensity between friends and enemies does that not also imply the possibility of limitless violence and destruction? The more intense a confrontation becomes, the more the appeal for a war of annihilation becomes accentuated. At extremes, the enemy is transformed into a "monster that must not only be defeated but utterly destroyed." 106 The perception of the threat posed by the enemy becomes so obsessive that only total conflict can expiate it. This, however, is where Schmitt seeks to formulate the proper limits, making sure that conflict

\footnotetext{
${ }^{103}$ Arendt, On Revolution. p. 12

${ }^{104}$ Schmitt, The Concept of the Political. p. 53

${ }^{105}$ Arendt, On Revolution. p. 77-78

${ }^{106}$ Schmitt, The Concept of the Political. p. 36
} 
remains within moderate boundaries. Schmitt refuses to aestheticize, moralize, or even dehumanize the enemy because the risk of infusing the political with normative considerations can transform an enemy into a foe. ${ }^{107}$ The foe, by definition, is a personal enemy that can be subject to this form of intense hatred. Thus, a clear distinction, between public enemy and foe is apparent in Schmitt. As Schmitt puts it, "The enemy is hostis, not inimicus in the broad sense; polemos not echthros." ${ }^{108}$ In fact, Schmitt refuses to accept any norm that justifies the killing of another, except when an existential threat is posed by an "other":

There exists no rational purpose, no norm no matter how true, no program no matter how
exemplary, no social ideal no matter how beautiful, no legitimacy nor legality which
could justify men killing each other for this reason. If such physical destruction of human
life is not motivated by an existential threat to one's own way of life, then it cannot be
justified. Just as little wars can be justified by ethical and juristic norms. If there really
are enemies in the existential sense as meant here, then it is justified, but only politically,
to repel and fight them physically. ${ }^{109}$

What primarily concerns Schmitt in the modern world is precisely an infusion of humanitarian morality within the political space that he argues, leads to a limitless escalation of conflict. As Schmitt remarks, "The worst confusion arises when concepts such as justice and freedom are used to legitimate one's own political ambitions and to disqualify and demoralize the enemy." 110 Wars for the sake of humanity and wars to end

\footnotetext{
${ }^{107}$ And yet Schmitt gives as an exemplary example of modern enmity that of Oliver Cromwell's stance towards Papist Spain. He quotes Cromwell as describing the Spanish enemy as "your great Enemy...he is the natural enemy. He is naturally so; he is naturally so throughout, - by reason of that enmity that is in him against whatsoever is of God. Whatsoever of God which is in you, or which may be in you." Ibid. p. 68;

${ }^{108}$ Ibid. p. 28 My transliteration from Greek to Latin characters. In a footnote on p. 29 Schmitt quotes Forcellini Lexicon totius latinitatis, II, 684: "A public enemy (hostis) is one with whom we are at war publicly... In this respect he differs from a private enemy. He is a person with whom we have private quarrels. They may also be distinguished as follows: a private enemy is a person who hates us, whereas a public enemy is a person who fights us."
}

${ }^{109}$ Ibid. p. 49 My emphasis

${ }^{110}$ Ibid. p. 66 
all wars that emasculate the enemy by going so far as to deny the mere life of the other can lead to utmost brutality. The concept of "humanity" has been an extremely useful tool for justifying all types imperialist expansions and aggressive military actions. However, "the concept of humanity excludes the concept of the enemy, because the enemy does not cease to be a human being - and hence there is no specific differentiation in the concept." 111 While during the medieval period the distinction between Christian and Muslim was made on a theological basis - where non-believers retained their soul and there always remained the ability of atonement through conversion - using the concept of humanity as a differentiating concept "fixes" the distinction between friend and enemy. ${ }^{112}$ In this case, there can be no primordial recognition of the "other" as an equal in conflict and thus the self "can, thereby be driven to the most extreme inhumanity." 113

Against moral universalism, Schmitt once again seeks to reassert a neutral space for the political devoid of moralizing or ideological considerations that have the potential of increasing the ferocity and destruction of war. Schmitt consciously seeks to reassert the "real" nature of the political particularly among states that has been clouded by liberalism's focus on culture and society. Schmitt speaks of the inability to "escape this logical conclusion of the political" where any attempts to negate it through humanitarian morality and wars to end all wars can lead to the most inhumane conflicts. ${ }^{114}$ This

\footnotetext{
${ }^{111}$ Ibid. p. 54 My emphasis

112 William Rasch, "Human Rights as Geopolitics; Carl Schmitt and the Legal Form of American Supremacy," Cultural Critique 54, no. 1 (2003).p. 131

${ }^{113}$ Schmitt, The Concept of the Political. p. 54
} 
paradox of attempting to neutralize the political, by attempting to extinguish all friend and enemy groups, leads to a hyper-politicization of conflict with those that are considered the enemy of humanity. Still, within Schmitt's own desire to reassert the political there is a fundamental ambiguity. Speaking of whether there can emerge a power that unifies the globe, Schmitt describes such a situation as the end of the political since the "distinction between friend and enemy would also cease to exist." ${ }^{15}$ In its place will be subcategories that remain part of civil society but do not constitute in themselves political distinctions as described above. Nonetheless, Schmitt writes, "If and when this condition appears, I do not know." 116 Hence, the negation of the political, as understood as the intense conflict between social groups, is in itself theoretically possible, and the autonomous domains of culture (entertainment) can appear as its replacement. Schmitt attempts to reassert the political can be viewed as a polemic against the emergence such a world. The dominance of liberal-democracy coupled with a growing emphasis on a capitalistic utilitarian economic model reinforced Schmitt's view that this age is inherently nihilistic. Schmitt's desire to reassert the concept of the political is intimately related to his own aspiration for meaning in the modern age. Politics, for Schmitt, is destiny while the decision of determining the identity of the public enemy is ultimately the most meaningful act that any political community can make.

\footnotetext{
${ }^{114}$ Ibid. p. 36

${ }^{115}$ Ibid. p. 53

${ }^{116}$ Ibid. pp. 53-54
} 


\section{Leo Strauss's Commentary on Schmitt}

While Schmitt polemicizes against the possibility of a depoliticized and neutralized modern world because of the conflation of liberalism with political romanticism, it remains debatable whether he can succeed in his original endeavor to extract and establish a "neutral" conception of the political "outside" of liberalism. Leo Strauss's commentary on The Concept of the Political seeks to confirm this very point. According to Strauss, all presuppositions of culture require a conception of nature; "culture is always the culture of nature." 117 In this statement, we should understand that the cultivation of human nature is the primordial claim in negating the state of nature as the state of war. ${ }^{118}$ Strauss argues that Schmitt, by allowing for the possibility of the political being threatened by culture in the face of a unified globe, in reality radically underestimates the nature of man's "dangerousness." "119 The relationship between the negation of the political and its affirmation, as Strauss confirms, "can be traced back to a quarrel of human nature. The ultimate controversy is whether man is by nature good or evil." 120 In this case, evil for Schmitt would be characterized by a mixture of "corruption, weakness, cowardice, stupidity, or also as, brutality, sensuality, vitality, irrationality," in other words, as a set of emotive characteristics that are construed as "dangerous." 21 Yet, as Strauss notes, "Hobbes had to understand evil as innocent 'evil' because he denied sin;

\footnotetext{
${ }^{117}$ Leo Strauss, "Notes on Carl Schmitt: The Concept of the Political," in The Concept of the Political, ed. George Schwab (Chicago: University of Chicago Press, 1996). p. 89 Authors italics

118 Ibid. p. 90

${ }^{119}$ Ibid. p. 96

${ }^{120}$ Schmitt, The Concept of the Political. p.95

${ }^{121}$ Ibid. p. 58
} 
and he had to deny sin because he did not recognize any primary obligation of man that takes precedence over every claim qua justified claim, because as by nature free, that is, without obligation..."122 The implication here is that, with the passage from the state of nature to the state of culture, man through reason can "learn" to become less dangerous. If this is true, Strauss continues, this explains the emergence of a moral relativism whereby "the opposition between evil and good loses its keen edge..." precisely because there are no fixed standards for establishing an absolute moral dichotomy. ${ }^{123}$

Strauss continues his critique by uncovering Schmitt's necessity for affirming the political in the face of a "depoliticized world." Strauss argues poignantly that by using Hobbes as the basis for his concept of the political, Schmitt is, in fact, unable to break free from the very liberal framework that he himself seeks to criticize. Precisely because Hobbes was so concerned with the physical safety of individuals within the state of nature, he invariably constructed the apparatus of the state for the sole purpose of securitizing the biological individual. ${ }^{124}$ No longer is the political concerned, as Strauss argues, with the "virtue" or the just society, as was the basis of classical Platonic political philosophy. Rather the political is concerned with the expedient necessity of survival. But Hobbes leaves open the door for resisting the demands of the sovereign and thus enables a space of freedom for human subjectivity. Here we recall that the Hobbesian sovereign cannot demand a "man to kill, wound, or maim himself", nor force a man to "die for the

\footnotetext{
122 Strauss, "Notes on Carl Schmitt: The Concept of the Political." p. 99

123 Ibid.

${ }^{124}$ Ibid. p. 91; Paul Gottfried, Carl Schmitt: Politics and Theory, Contributions in Political Science, No. 264 (New York: Greenwood Press, 1990). p. 41; Strauss, The Political Philosophy of Hobbes : Its Basis and Its Genesis.; McCormick, "Fear, Technology, and the State: Carl Schmitt, Leo Strauss and the Revival of Hobbes in Weimar and National Socialist Germany." pp. 632-633
} 
sovereign" against an enemy. ${ }^{125}$ For Strauss, then, Hobbes represents the founding father of modern liberalism that opens the door to future conceptualizations of "human rights." ${ }^{\prime 26}$ Accordingly, the principal culprit for the rise of humanitarian morality for Strauss is Hobbes himself. According to Strauss, Schmitt's conceptualization of the political is inevitably fused with the question of humanitarian morality and in liberalism in general. Schmitt affirms the political because of the possibility that its negation may render life unserious or inauthentic. Strauss concludes: "The affirmation of the political is ultimately nothing other than the affirmation of the moral."127 The implication of attempting to affirm the political grounded in a moral relativism, as Strauss describes it, is in fact nothing more than a "liberalism of the opposite polarity." Concluding this critique by Strauss in full:

Let us now make thoroughly clear what the affirmation of the political in disregard of the moral, the primacy of the political, would signify. Being political means being oriented to the "dire emergency." Therefore the affirmation of the political as such is an affirmation of fighting as such, wholly irrespective of what is being fought for. In other words: he who affirms the political as such comports himself neutrally toward all groupings into friends and enemies. However much this neutrality may differ from the neutrality of the man who denies the political as such, he who affirms the political as such and thereby behaves neutrally toward all groupings into friends and enemies does not want 'to place' himself 'outside the political totality... and live only as a private man; he does not have the will to neutralization, to the avoidance of decision at all costs, but is in fact eager for decision; as eagerness for any decision regardless of content, this neutrality makes use of the possibility - which originally was made accessible for the sake of neutralization - of something beyond all decision. He who affirms the political as such respects all who want to fight; he is just as tolerant as the liberals - but with the opposite intention: whereas the liberal respects and tolerates all "honest" convictions so long as they merely acknowledge the legal order, peace, as sacrosanct, he who affirms the political as such respects and tolerates all "serious" convictions, that is, all decisions orientated towards the real possibility of war. Thus the affirmation of the political as such proves to be a liberalism of the opposite polarity. ${ }^{128}$

\footnotetext{
${ }^{125}$ Hobbes, Leviathan : With Selected Variants from the Latin Edition of 1668. p. 142-143

${ }^{126}$ Strauss, "Notes on Carl Schmitt: The Concept of the Political." pp. 91, 99

${ }^{127}$ Ibid. p. 101

${ }^{128}$ Ibid. p. 105 Emphasis in the original
} 
Strauss's critique resonated deeply with Schmitt. In the preface to his book that uncovers the hidden dialogue between Strauss and Schmitt, Meier remarks that upon reading Strauss's "Notes" Schmitt was said to have mentioned to his student Günther Krauss: "You've got to read that. He saw through me and X-rayed me as nobody else has. " ${ }^{129}$ In fact, Strauss's commentary would continue to form the backdrop of Schmitt's own further investigations into how the political becomes nested into different historical settings. In addition, the Straussian charge that Schmitt's critique of liberalism is itself nothing more than a "liberalism of the opposite polarity" adumbrates Schmitt's own extrapolation of the concept of enmity in diverse international juridical contexts; the moral relativism associated with a neutralized moral and theological sphere represented in the Jus Publicum Europaeum is taken by Schmitt as the archetype for the concrete and "bracketed" concept of the political and affirms a liberal tendency within Schmitt's opus on international jurisprudence. This is what will be explored in the subsequent chapter.

${ }^{129}$ Meier, Carl Schmitt \& Leo Strauss: The Hidden Dialogue. p. xvii 


\section{Carl Schmitt on International Order}

\section{Introduction}

The previous chapter established the foundations of Carl Schmitt's political and legal thinking. These foundations, it was argued, were intimately associated with a deeply held conservative worldview that had a profound disdain for liberal-bourgeois society. At the time when the political and social situation within Germany was deteriorating and the Weimar republic was in grave danger, Schmitt actively sided with a conservative/National Socialist coalition whose principal electoral position was a restoration of order. His consistent decisionist stance found fruition in the years following the parliamentary crisis of 1932-1933. With the coming to power of the National Socialist movement, Schmitt's early membership in the Nazi party, along with that of the philosopher Martin Heidegger, signaled his own initial wholehearted embracing of the Nazi state. ${ }^{1}$ It would not be sufficient for Schmitt to support the Nazi movement from the periphery; rather he lent his juridical and political writings in an attempt to enhance its appeal and legitimacy.

After the Reichstag fire on February $27^{\text {th }}$ and the parliamentary elections of March $5^{\text {th }}, 1933$, Hitler forcibly passed through parliament the Enabling Act, which effectively granted the executive power the legitimate right to enact decrees that had the force of law. ${ }^{2}$ The bulk of civil liberties articulated in the constitution were suspended while political opponents, initially primarily members of the Communist Party, were

\footnotetext{
${ }^{1}$ Balakrishnan, The Enemy: An Intellectual Portrait of Carl Schmitt. p. 181; Balakrishnan writes that "Schmitt received a letter from Martin Heidegger which urged him to join the [Nazi] party...on 1 May both men waited in long queues to become party members."

${ }^{2}$ Ibid. p. 177
} 
rounded up and placed in concentration camps. The result was the perpetual suspension of the Weimar constitution due to a generalized state of exception; yet all the while maintaining in place the basic constitutional structures of the constitution. ${ }^{3}$ Schmitt, while adapting his decisionist theory of state by not using his previously developed categories of sovereign or commissarial dictatorship, supported the Enabling Act and affirmed that "the Weimar constitution [as a whole] no longer valid."4

It was during these early years of National Socialism that Schmitt would distinguish himself as the "crown jurist" of the third Reich. He published, in 1933, an article profoundly critical of intellectuals who fled Nazi Germany, even going so far as to call Albert Einstein a "poison-filled German hater.", 5 More important, however, was the publication of Staat, Bewegung, Volk (State, Movement, People). ${ }^{6}$ The premise of this text was Schmitt's attempt at reconciling the relationship between the state and the Nazi party. While the state remained the bureaucratic instrument, the movement embodied the political leadership that ruled for the people. As Balakrishnan writes: "The 'people' was the region of a new political system which was once a legally and institutionally distinct

\footnotetext{
${ }^{3}$ Agamben revealingly writes: "The state of exception thus ceases to be referred to as an external and provisional state of factual danger and comes to be confused with the juridical rule itself." Agamben, Homo Sacer: Sovereign Power and Bare Life. This state of affairs was not Schmitt's own understanding of what the state of exception juridically signifies. Rather, as has been argued in the previous chapter, the state of exception has a temporally finite quality. The sovereign must restore a state of normalcy during that time period. On the other hand, Walter Benjamin in his eighth thesis on the philosophy of history, as Agamben argues, offers a critique directed at Schmitt and writes: "The tradition of the oppressed teaches us that the 'state of emergency' in which we live is not the exception but the rule. We must attain to a conception of history that is in keeping with this insight. Then we shall clearly realize that it is our task to bring about a real state of emergency, and this will improve our position in the struggle against Fascism." Walter Benjamin, Illuminations, ed. Hannah Arendt, trans. Harry Zohn (New York: Schocken Books, 1986).; See as well Agamben, State of Exception. pp. 57-58

${ }^{4}$ Quoted from Schwab, The Challenge of the Exception: An Introduction to the Political Ideas of Carl Schmitt between 1921 and 1936. p. 104

${ }^{5}$ Quoted in Balakrishnan, The Enemy: An Intellectual Portrait of Carl Schmitt. p. 183

${ }^{6}$ Carl Schmitt, State, Movement, People: The Triadic Structure of the Political Unity, trans. Simona Draghici (Corvallis: Plutarch Press, 2001).
} 
'civil society', and now consisted of a multitude 'living in the shadow and under the protection of decisions reached in the higher regions of the political order'.,7 The explicit denigration of the 'people' and 'civil society' reflected Schmitt's persistent attempts at combating the perceived spiritual pathology of the liberal-democratic ethos. Until approximately 1936, Schmitt consistently applied his juridical writings in favor of the Nazi state, shamelessly justifying the extra-judicial purge of the Sturm Abteilung (SA) and that of its head, Ernst Röhm, in 1934 during the so-called night of long knives. It would also be during this period that the most virulent forms of anti-Semitism would emerge in his writings. Seeing that his enemies within the Schutzstaffeln (SS) and the Nazi party, who unearthed his prior relationships to prominent Jewish intellectuals and the Catholic conservative political parties, were undermining his academic and political positions in Germany, Schmitt sought to enhance his anti-Semitic credentials by hailing the Nuremberg Laws of 1935 as: "The Constitution of Freedom." ${ }^{\text {" }}$ Moreover, as a keynote speaker at a conference on jurisprudence in 1936, Schmitt began by trying to demonstrate the lingering Judaic influences on German jurisprudence. He declared the Jewish threat as one of "Jewish chaos and Jewish legality...anarchist nihilism and positivist normativism...raw sensualist materialism and abstract moralism."9

\footnotetext{
${ }^{7}$ Balakrishnan, The Enemy: An Intellectual Portrait of Carl Schmitt. p. 185

${ }^{8}$ Ibid. p. 206; John Herz ever argues that Schmitt's initial references to the "other" and the "stranger" beginning with Schmitt's The Concept of the Political are implicit references towards Jews. See John H. Herz, "Looking at Carl Schmitt from the Vantage Point of the 1990's," Interpretation 19, no. 3 (1992). P. 308; In a different reading, Mika Ojakangas argues that Schmitt's real enemy during the Nazi period was the assimilated Jew who could not be clearly identified. See Mika Ojakangas, "Carl Schmitt's Real Enemy: The Citizen of the Non-Exclusive Democratic Community?," The European Legacy 8, no. 4 (2003).; On the other hand, Wolfgang Palaver argues that "Schmitt's position is clearly anti-Semitic, but this label does not help understand his approach. His anti-Semitism is not based on racism, but on his concept of space...Schmitt focuses on soil not on blood." Palaver, "Carl Sclımitt on Nomos and Space." p. 115
}

${ }^{9}$ Quoted in Balakrishnan, The Enemy: An Intellectual Portrait of Carl Schmitt. p. 206 
However, these anti-Semitic diatribes along with his support of Hitler's policies to transform the German legal system and academic environment were not enough to save Schmitt from the internal purge of all but the most ideological and zealous Nazis. As with Heidegger's ill-fated flirtation with the Nazi party, major intellectuals who placed their hopes in being able to "influence" Hitler and the movement ended up being discarded as anachronistic. Schmitt found himself assailed from different sides for his previous writings in support of political Catholicism and his proposal to enact Article 48 to crush the Nazi and communist parties. The year 1936 marked the end of Schmitt's political engagement with the Nazis after a deeply threatening article against him appeared in the weekly SS journal Schwarze Korps. ${ }^{10}$ While he remained a professor at Berlin University, his public role withm Nazi Germany became ever more marginalized.

\section{The Turn Towards International Law}

Though 1936 marked Schmitt's fall from grace and his return to more academic pursuits, his turn towards problems in international law was, in a way, prefigured in his polemics against the Versailles treaty of $1919 .{ }^{11}$ After it was signed, the Versailles treaty was generally perceived in Germany as embodying the "imperialistic" and "moralizing" tendencies of the Allied powers, particularly France. Whereas prior peace treaties involved a recognized equality among the parties in a negotiated settlement, Versailles' raison d'etre was specifically to criminalize and punish Germany for the perceived

\footnotetext{
${ }^{10}$ Julien Freund, "Schmitt's Political Thought," Telos, no. 102 (1995).

${ }^{11}$ Müller, A Dangerous Mind: Carl Schmitt in Post-War European Thought. pp. 24-25; See also Peter M. R. Stirk, "Carl Schmitt's Enemy and the Rhetoric of Anti-Interventionism," The European Legacy 8, no. 1 (2003). For a more critical review of Schmitt's Weimar writings on international law.
} 
aggression that it committed at the onset of the First World War. ${ }^{12}$ The Allied treatment of the Kaiser as a war criminal had no precedent in prior European conflicts. This, in particular, Schmitt took to be a clear indication of the progressive breakdown of the European order of states that valued the legal equality of sovereigns even during war. The new world order of 1919, with Wilson's fourteen points and the establishment of a community of states centered on the League of Nations, was simply perceived in Germany as reflecting the victors' own geopolitical interests. What the Allied victors considered a properly constituted and just international order, Schmitt argued, revealed nothing more than their own political necessities masked as self-righteous morality. As Anthony Carty notes, "Schmitt demonstrates quite clearly how legal arguments can always be reduced to expressions of interest determined by space, location etc..."13 In which case, the normative content of legal norms is of secondary importance. Rather, the fundamental principle of any legal order resides in the question: to whom belongs the capacity to decide? Who decides what is a just cause or a just war? Who decides when an action needs to be undertaken or when sanctions need to be applied? Ultimately, who decides on the legal obligations of a state and its ability to change those obligations, i.e. rebus sic stantibus? Given Schmitt's own emphasis on linking sovereignty to a moment of decision on the exception, this extends his focus on the political impulses that govern legal orders. As Schmitt wrote in a review of Friedrich Meinecke's classic work Die Idee der Staatsräson in der neuern Geschichte:

\footnotetext{
${ }^{12}$ Woods, The Conservative Revolution in the Weimar Republic. p. 27; In particular the "war-guilt" clause of the Versailles was deeply resented among the conservative parties in Germany that saw this as an attempt to subjugate Germany to a set of "alien values."

${ }^{13}$ Anthony Carty, "Carl Schmitt's Critique of Liberal International Legal Order between 1933 and 1945," Leiden Journal of International Law 14 (2001). p. 39
} 
The problem does not lie in the normative content of a moral or legal commandment, but in the question of who decides?... Of course, everyone wants justice, morality, ethics and peace, no one wants to do wrong; but the only interesting question in concreto is always who decides in each specific case what is right, what peace consists in, what the threat to peace or a breach of the peace is, how it is to be eliminated and when a situation is normal and 'pacified', etc. This quis iudicabit [who decides] shows that within the law and the general commandment to be moral, a dualism lies concealed that robs these concepts of the ability to stand up to 'power' as simple opposing principles and to swing the pendulum-like towards it. ${ }^{14}$

This question of who decides, which has been shown to be ultimately related to Schmitt's understanding of sovereignty, becomes the central question in figuring out the meaning of juridical concepts in international law. However, before going into Schmitt's interpretation of the rise and fall of the European state-system and the constitution of the Jus Publicum Europaeum, it is necessary to first return to Schmitt's treatment of Hobbes' Leviathan and then to understand the very nature of concrete-order thinking (konkreteordnug) and the differentiation between the spatial concepts of land and sea.

At the end of chapter one, we saw that the young Leo Strauss' commentary on The Concept of the Political demonstrated that the political for Schmitt remained mired in the very liberalism it meant to critique. As Strauss confirmed, Schmitt's reliance upon Hobbes implicated him in a "liberalism of the opposite polarity." Nonetheless, Schmitt, in his 1938 work on Hobbes tried to answer Strauss's criticism through a mythical reading of the imagery of the Leviathan. ${ }^{15}$ By doing this, Schmitt meant to reassert the

${ }^{14}$ Quoted in Hans Joas, War and Modernity, trans. Rodney Livingstone (Cambridge: Polity Press, 2003). pp. 38-39; Meinecke's work was later translated as Meinecke, Machiavellism: The Doctrine of Raison D'etat and Its Place in Modern History.

${ }^{15}$ Schmitt, The Leviathan in the State Theory of Thomas Hobbes: Meaning and Failure of a Political Symbol:; The attempts by Schmitt to reinsert a mythical aspect to the Hobbesian leviathan can have the most extreme consequences especially in conjunction with modern technology. National Socialism and Stalinism can both be viewed as the fateful nexus between unbridled powers embodied in the myth of the state and the technology of control and oppression. See McCormick, "Fear, Technology, and the State: Carl Schmitt, Leo Strauss and the Revival of Hobbes in Weimar and National Socialist Germany." p. 643; See as well Richard Overy, The Dictators (New York: W.W. Norton \& Company, 2004). Chapter 9 
symbolism of the mythic creature of the Book of Job as the fear inspiring entity that motivates obedience to the state. Rather than focusing on Hobbes as the initiator of the mechanization or instrumentalization of the state, Schmitt attributes this initial move to Spinoza. For Spinoza, Schmitt writes, "Individual freedom of thought is the form giving principle, the necessities of public peace as well as the right of the sovereign power having transformed into mere provisos." ${ }^{, 16}$ And yet, Schmitt in no way answers the charge that Hobbes' own natural right qualification, comprising the right to resist conscription or the executioner, represents the founding principle of modern liberalism. ${ }^{17}$

More significantly in this work, however, Schmitt began to differentiate between the political and legal concepts present within the continental land powers and maritime England. The image of the leviathan as the absolute mythic sea creature did not find its place in Hobbes' England but rather on the European continent that coalesced into a distinct set of absolute monarchies over territorially marked boundaries. ${ }^{18}$ Nation-states, such as France, Spain, and Prussia, formed the Hobbesian condition of sovereignty by accepting the absolutist form of decisionism within the supreme ruler. By contrast,

\footnotetext{
${ }^{16}$ Schmitt, The Leviathan in the State Theory of Thomas Hobbes: Meaning and Failure of a Political Symbol. p. 58; In the next sentence Schmitt writes: A small intellectual switch emanating from the nature of Jewish life accomplished, with the most simple logic and in the span of a few years, the decisive turn in the fate of the leviathan." The reference to the "nature of the Jewish life" continues Schmitt's own anti-Semitic groveling to the Nazi authorities. Schmitt's text on Hobbes is thoroughly contaminated with anti-Semitic remarks. George Schwab, in his introduction however, points to Schmitt's broadening of his attacks not only against Jews but against the "Roman papal church" and the "power-thirsty Presbyterian churches or sects."p. xxi

${ }^{17}$ Balakrishnan, The Enemy: An Intellectual Portrait of Carl Schmitt. p. 218; More will be said on this below.

${ }^{18}$ Schmitt, The Leviathan in the State Theory of Thomas Hobbes: Meaning and Failure of a Political Symbol. p. 79; For a detailed study of the formation of the absolutist regime in France and Prussia from a Marxist perspective see Perry Anderson, Lineages of the Absolutist State (London: N.L.B., 1974). pp. 85$112 \& 236-278$
} 
Schmitt argues, "the concept of sovereignty of the absolutist state...has found no echo in the public power of England." Schmitt continues:

Instead of cabinet- and combat-determined notions of land warfare waged by absolutist states on the continent, this sea power developed a concept of the enemy that had been derived from sea and trade wars, namely, the concept of a nonstate enemy that does not distinguish between combatants and noncombatants and hence is truly 'total. 19

Here we can begin to see an important change in Schmitt's thought on international geopolitics. Prior to the 1930s, Schmitt was primarily focused on the Soviet Union as the natural enemy of Europe as a whole. Marxism, along with its subsequent derivatives of bolshevism, socialism, and communism represented the fundamental antithesis to a Western European "culture."20 However, by the mid-1930s, Schmitt began instead to focus on the Anglo-American "sea powers" as the natural enemy of continental Europe. For one, this can be viewed as an extension of Schmitt's polemics against the Versailles treaty as an untraditional and unnatural imposition on a defeated Germany. Versailles, through its guilt clauses and criminalization of the Kaiser, represented a fundamental transformation of the very norm of sovereign equality. Gerry Simpson notes that Versailles "marked a profound shift from the $19^{\text {th }}$ century sensibility of forgiveness and rehabilitation of fallen enemies to a much more vindictive, anti-pluralist approach

\footnotetext{
${ }^{19}$ Schmitt, The Leviathan in the State Theory of Thomas Hobbes: Meaning and Failure of a Political Symbol.p. 80

${ }^{20}$ Schmitt, Roman Catholicism and Political Form. p. 38 Schmitt writes that "since the nineteenth century, there have been in Europe two great masses opposed to West European tradition and education, two great streams crowding their banks: the class conscious proletariat of the big cities and the Russian masses estranged from Europe. From the standpoint of traditional West European culture, both are barbarians. Were they have sense of their own power, they proudly call themselves barbarians. The fact that they met on Russian soil, in the Russian Soviet Republic, has a profound justification in the history of ideas. However dissimilar and even antagonistic the two groups, however inexplicable the whole process in terms of all previous ideological constructs and the specific theory of Marxism, the alliance is no accident of world history."
} 
towards the defeated powers. ${ }^{21}$ Moreover, during the debate concerning the criterion for membership within the League of Nations, anti-pluralist views became more vocal in asserting the necessity of only allowing those that possessed "liberal standards." This, Simpson continues, resulted in the fact that:

[Sovereign] Equality, then was a provisional right to be recognized and respected when a state possessed an appropriate political personality and was readily forfeited by anarchic government and bad behavior, e.g. aggression. ${ }^{22}$

Schmitt, however, traces the origins of this modern discriminatory conception of war back to the original notions of sea warfare that were first practiced by the AngloSaxon powers. In Land and Sea, Schmitt begins by asserting the difference between the spatial order of the sea and the order of the land. ${ }^{23}$ World history is the continuous conflict between land empires and sea empires. ${ }^{24}$ Both spatial environments have distinct notions of international law. On land, Schmitt writes, "not the civil population, but only the adversarial army was the enemy," and war for land empires was not "conducted between peoples, but only between the armies of the European states." 25 Likewise, private property during land wars remained sacrosanct and could not be considered "booty." On the other hand, sea warfare comprised a different set of rules that were linked primarily to economic gain: "Sea war was trade war." 26 There was no concept of

${ }^{21}$ Gerry Simpson, Great Powers and Outlaw States (Cambridge: Cambridge University Press, 2004). p. 260

${ }^{22}$ Ibid. p. 262

${ }^{23}$ Carl Schmitt, Land and Sea (Washington, DC: Plutarch Press, 1997).

${ }^{24}$ lbid. p. 5

${ }^{25}$ Carl Schmitt, The Nomos of the Earth in the International Law of the Jus Publicum Europaeum, trans. G. L. Ulmen (New York: Telos Press, 2003). p. 353 
neutrality on the sea; anyone trading with the opponent was considered "fair booty, according to blockade and prize law." Accordingly, Schmitt notes, "land and sea confronted each other as two separate worlds with completely different concepts of war, enemy, and booty."27 This Schmittian disjunction between land and sea warfare would have political and juridical repercussions on the concept of enmity and its evolution over time. David Cumin describes the implications of the emergence of sea warfare on international law as follows:

The "English" maritime war thus forged, imposed and ratified a complete system of international law as well as specific concepts of war and enmity. This war is "total" in the sense that it is likely to lead to total hostility, not only because it rejects the distinctions, specific to land warfare, between combatants and non-combatttants, but also because it develops, for the rationalization of a "liberal" imperialism and in the name of a "humane" ideology or of a certain "philosophy of history", doctrines of "just" wars which treats the enemy as a criminal and break the legal and moral equality between belligerents. ${ }^{28}$

The warfare practiced by the maritime powers progressively displaced the landbased norms practiced between states. Though well known was the British emphasis on maintaining the balance of power within Europe itself, the rest of the world was subject to economic and colonial hegemony. Naval domination became the primary focus because of the strategic necessity of maintaining the open seaways between different

\footnotetext{
${ }^{26}$ Ibid.

${ }^{27}$ Ibid.

${ }^{28}$ David Cumin, Thalassopolitique: Carl Schmitt Et La Mer (2000 [cited 07-10-2005 2005]); available from http://www.stratisc.org/pub/pn/PN7 Cumin.html. My translation of "La guerre maritime "anglaise" a ainsi forgé, imposé et entériné un système complet de droit international et des concepts spécifiques de guerre et d'ennemi: elle est "totale" au sens où elle est susceptible d'une hostilité totale, non seulement parce qu'elle rejette la distinction, propre à la guerre sur terre, entre combattants et non-combatttants, mais aussi parce qu'elle développe, pour le compte d'un impérialisme "libéral" et au nom d'une idéologie "humanitaire" ou d'une certaine "philosophie de l'histoire", une doctrine de la guerre "juste" qui assimile l'ennemi à un criminel et rompt l'égalité juridique et morale des belligerents." It should be said, however, that Germany did conduct unrestricted warfare during World War I, which would ultimately bring in the United States on the side of the Allies.
} 
parts of the British Empire. The struggle between Italy and Britain in the Mediterranean reflected an inability to reconcile, on the part of the British, the possibility of other powers establishing spheres of influence over sea-lanes. Later, starting in the mid- $19^{\text {th }}$ century, the US trade and commercial "empire" would devise a similar rationale for forcing the opening of global markets and considered it a matter of national security when the free flow of trade was threatened. These global geopolitical interests, which were ultimately tied to the demands of maintaining a global empire, morphed into moral and "progressive" ideological justifications. The emerging universal idea of "one world" linked by economic interests rendered problematic territorial boundaries as spaces of non-intervention. ${ }^{29}$ Jennifer Pitt, for example, demonstrates how this transformation occurred through the writings of James Mill and John Stuart Mill in Britain and Alexis de Tocqueville in France. ${ }^{30}$ Wedded to a utilitarian moral conception of the good, these writers exhibited a growing confidence in the attributes of their own civilization to legitimate their rule over others. Notions of progress, economic development, and industrialization are wrapped around a liberal idealism that, while promoting theories of "civilizational deficiencies" among non-Europeans, instantiates global visions of homogeneity. ${ }^{31}$ It is this particular universalism that devalued difference for the sake of progress and that would latter turn on itself by negating the very possibilities of neutrality. Late nineteenth century and early twentieth liberal universalism would render the concrete notions of neutrality, war, and peace highly problematic.

\footnotetext{
${ }^{29}$ Schmitt, The Nomos of the Earth in the International Law of the Jus Publicum Europaeum. p. 226

${ }^{30}$ Jennifer Pitts, A Turn to Empire: The Rise of Imperial Liberalism in Britain and France (Princeton: Princeton University Press, 2005).

${ }^{31}$ Ibid. p. 21
} 
Schmitt saw this growing universalization of liberal values as a way of reemploying a conception of just war that was not present since the medieval epoch. ${ }^{32}$ Although during that time, just war concepts were grounded in the Christian theology of Augustine and Aquinas, Schmitt regarded the modern retrieval as a nihilistic and effervescent attempt at forging competing values. Hans Morgenthau himself has many times articulated the problematic nature of utilizing such a universal claim to justice as a way to overpower the traditional delimitations between morality and political necessity:

The appeal to moral principles in the international sphere has no concrete universal meaning. It is either so vague as to have no concrete meaning that could provide rational guidance for political action, or it will be nothing but a reflection of the moral preconceptions of a particular nation and will be the same token be unable to gain the universal recognition it pretends to deserve. ${ }^{33}$

Morgenthau is correct in pointing out the vacuous nature of universal claims to morality for the sake of foreign policy making. Moreover, the result of infusing the international juridical order with a universal conception of war based on a humanitarian moralism that relies on constantly changing "values", Schmitt saw, was intrinsically related to, on the one hand, the depoliticization and neutralization of the state, and, on the other hand, with attempts at creating a genuine international constitutional federalism with the League of Nations that reduced questions of violence in inter-state relations to a form of criminal law. External sovereignty is devalued in the name of humanitarian interventionism, which reflects a universal moralism. Yet the dilemma present in such a configuration of

\footnotetext{
${ }^{32}$ Certainly the notion of a just cause and normativist conception of jurisprudence has its roots in Roman law. See Carl Schmitt, "The Plight of European Jurisprudence," Telos 83 (1990). pp. 39-44

${ }^{33}$ Quoted in Martii Koskenniemi, The Gentle Civilizer of Nations: The Rise and Fall of International Law 1870-1960 (Cambridge: Cambridge University Press, 2002). p. 438; Hans Joachim Morgenthau, In Defense of the National Interest: A Critical Examination of American Foreign Policy (New York,: Knopf, 1951). p. 35
} 
was simply to realign the friend-enemy distinction between members and non-members and to accelerate the intensity of confrontation between the two. ${ }^{34}$

The humanitarian moral conception does nothing to address the very real problematic meaning of such concepts as neutrality, war, and peace. Starting with the Geneva protocols of 1924, which contained the clause that aggression can be considered a crime, and the Kellogg-Briand attempt of 1928 to "condemn war as a national policy" the setting was set for the arbitrary criminalization between political opponents even if they were members of the League itself. ${ }^{35}$ Thus no longer would we speak of a set of public and equal opponents as traditionally understood between sovereigns, but rather we would now encounter a bifurcation between the criminal "gangster" state and the "enforcer" or policeman. ${ }^{36}$ War would no longer be, as Quincy Wright defined it in his canonical text $A$ Study of War, "a state of law, a form of conflict involving a high degree of legal equality, of hostility, and of violence in the relations of organized human groups..."37 it would rather become an asymmetrical struggle that recognizes no boundaries or rights for which the enemy is entitled. The enemy, then, is transformed into that of the foe, the brigand, or, as in today's terminology, a "rogue state" where the political friend-enemy relationship is accentuated.

The consequence of transforming war into "police" actions, which act as a form of punishment, is a radical transformation of the concept of neutrality. Martti

${ }^{34}$ Carl Schmitt, War/Non-War?: A Dilemma, trans. Simona Draghici (Corvallis, OR: Plutarch Press, 2003). pp. $40-41$

${ }^{35}$ Schmitt, The Nomos of the Earth in the International Law of the Jus Publicum Europaeum. p. 271

${ }^{36}$ Schmitt, War/Non-War?: A Dilemma.p. 43

${ }^{37}$ Quincy Wright, A Study of War, ed. Louise Leonard Wright, Abridged ed. (Chicago: University of Chicago Press, 1983). p. 7 my emphasis 
Koskenniemi notes amusingly that "There can be no neutrality between the policeman and the thief." 38 Indeed, for Schmitt, "the destruction of neutrality lead to the spatial chaos of a global world war and to the dissolution of 'peace' into ideological demands for intervention lacking any spatial concreteness or structure." 39 Even the concept of peace is problematic today because, as William Rasch argues, "Peace no longer stands in relation to war, one defining the other, but has become and absolute norm, a moral club with which one mercilessly beats one's opponents." ${ }^{, 40}$ This lack of "any spatial concreteness of structure" transforms war from a conflict between states on equal terms to global civil wars that lack an intrinsic spatial boundary. Much like piracy was considered "outside" the law, states that engage in such a defined "aggression," often defined at the discretion of the status quo powers, are no longer considered to be members of the community of nations and subject to punitive sanctions. The punitative measures imposed on a given country are to be applied against the "criminals" running the state though more often than not it was the local non-combatant population that suffers the consequences.

The price of establishing discriminatory conceptions of war and peace would be to create an environment for the violent escalation of conflicts into total wars of annihilation. However, as it should be clear, it is not simply a matter of weaponry that renders a potential conflict "total." Rather, as Schmitt writes, "it is the total enemy that

\footnotetext{
${ }^{38}$ Koskenniemi, The Gentle Civilizer of Nations: The Rise and Fall of International Law 1870-1960. p. 425

${ }^{39}$ Schmitt, The Nomos of the Earth in the International Law of the Jus Publicum Europaeum. p. 246; Stirk chides Schmitt for appealing to a concept of neutrality when all while he has consistently derided neutrality as a "liberal" concept that negates the ability of the state to decide the extreme situation. Stirk, "Carl Schmitt's Enemy and the Rhetoric of Anti-Interventionism." p. 30-31 However, Stirk confuses the different concepts between external neutrality which is based on recognition of other states and the interior concept of neutrality which negates the states own ability to effectively decide.

${ }^{40}$ William Rasch, "Introduction: Carl Schmitt and the New World Order," South Atlantic Quarterly 104, no. 2 (2005).p. 182
} 
gives the total war its meaning." ${ }^{41}$ Schmitt decried this situation because of its intrinsic chaotic structure, its inability to conceive of not only difference and particularity through a respect for the rights of political enemies, but also for its inability of determining what the sources of legitimate action in international politics are. Michael Hardt and Antonio Negri argue as much when they claim that the loosening of traditional political structures and concepts - for example, the nation-state as the sole authority for the decision on war and peace - results in that fact that the "distinctions between legitimate and illegitimate violence, between wars of liberation and wars of oppression, tend to blur."42 This blurring of the lines in and opaqueness of the world order is seen particularly in today's "war on terror" that does not recognize traditional boundaries or forms. Enemies or foes can be present everywhere and anywhere, while the prosecution of the war is ever more amorphous in its boundaries. What Sheldon Wolin sees as the current war between two "formless forms," that of "Superpower" (or as Hardt and Negri would call Empire) and terrorism, is a recognition of a lack of concreteness in contemporary political concepts whereby the lines demarcating the validity of juridical concepts change according to ideological considerations. ${ }^{43}$ As will be seen below, the traditional form of the European public order was a concrete order that did not eliminate war but bracketed it. However, the current world order renders problematic the traditional conceptual distinction between war, peace and neutrality to the point of indistinction. Neutrality can no longer be considered a matter of foreign policy choice, but rather becomes a devalued concept that

\footnotetext{
${ }^{41}$ Carl Schmitt, "Total Enemy, Total War, Total State," in Four Articles: 1931-1938, ed. Simona Draghici (Corvallis: Plutarch Press, 2001). p. 29 my emphasis

${ }^{42}$ Hardt and Negri, Multitude: War and Democracy in the Age of Empire. p. 32 emphasis in the original

${ }^{43}$ Wolin, Politics and Vision: Continuity and Innovation in Western Political Thought. p. 559
} 
is subject to the will of particular great powers and that obligates other states to observe its demands in the name of abstract ideals such as "humanity" or "civilization." However, as has been argued in the previous chapter, utilizing the concept of humanity can, in fact, heighten a conflict by creating an asymmetrical difference resulting in the creation of the "non-human." As Schmitt wrote in 1978:

If one discriminates between within humanity and thereby denies the quality of being human to a disturber or destroyer, then the negatively-valued person becomes an unperson [sic] and his life is no longer the highest value: it becomes worthless and must be destroyed. ${ }^{45}$

The product of introducing a discriminatory and asymmetrical concept such as "human / non-human" within the sphere of international politics reinforces the claim that the political has been transformed into the biopolitical paradigm that results in the politicization of the human body. Schmitt, and also Arendt, early on recognized the inbuilt dystopia within the liberal premise of transforming the political into an economics, an ethics, and ultimately a politics of humanity itself, which would create a capitalistic / liberal-democratic utopia without difference or division. Though much more will be said on this matter in the subsequent chapter, this dystopia, as inherently lacking in topos or a conception of spatiality because of its universalism, results in the fateful consequence of redefining the legal and political boundaries, that is, the "line" that

\footnotetext{
${ }^{44}$ Schmitt, War/Non-War?: A Dilemma. p. 40 Schmitt continues by writing on page 41 that "As soon as an international legal order distinguishes between legal and illegal wars, with effectively supranational legal force for the third states, the armed action is on the legal side nothing but judiciary procedure, execution, sanction, international justice or police: on the illegal side, it is only resistance to the lawful actions rebellion or crime, and each time something different from 'war', the traditional legal institution."
}

${ }^{45}$ Carl Schmitt, "The Legal World Revolution," Telos, no. 27 (1987). p. 88 
defines the inside and outside, according to the model of the modern concentration camp. $^{46}$

Schmitt was one of the first political theorists to realize this disjuncture between traditional political and legal concepts and their territorial rootedness in the modern world. The lack of clarity and concreteness of the contemporary international legal order provoked a sense of anxiety that Schmitt captured well in the late 1930s:

The anxiety of the present world situation is mirrored in the problematic of the concept of war. It demonstrates what has always been true - that the history of international law is a history of the concept of war. International law is clearly a 'law of war and peace,' ius belli ac pacis, and will remain so long as it is the prerogative of independent peoples organized into states, i.e., as long as war obtains between states and it is not an international civil war. Every dissolution of old orders and every attempt to create new types of association raises this problem. Within one and the same order of international law there cannot be two antithetical concepts of war any more than two different concepts of neutrality. ${ }^{47}$

The above passage should not be solely construed as simply a resistance to changes happening in the international order. It signifies instead Schmitt's position that the current perceptions of international juridical concepts are not fully grounded in a spatial location that has been the hallmark of previous orders. Thus Schmitt's goal was to recuperate the traditional relationship between conceptions of international law and order and their spatial underpinnings as a way of combating the very universalism and abstract normativism that he held to be responsible for the $20^{\text {th }}$ century's inability to properly conceptualize the meaning of war and, ultimately, its ability to bracket it. Consequently, Schmitt sought to retrieve a more traditional understanding of how law emerges with respect to a concrete spatial ordering. By looking into how law becomes wedded to

\footnotetext{
${ }^{46}$ Agamben, Homo Sacer: Sovereign Power and Bare Life.

${ }^{47}$ Quoted in G. L. Ulmen, "Just Wars or Just Enemies," Telos 109 (1996). p. 104
} 
principles of land-appropriation, Schmitt sought to devise a more historical understanding of how juridical concepts emerge. In a retrieval of the presumptions underlying the $19^{\text {th }}$ century German legal historian F. C. Savigny, Schmitt writes:

Law as concrete order must not be separated from its history. True law is not imposed; it arises from unintentional elements. It reveals itself in the concrete for of jurisprudence, through which it becomes conscious of its development. For Savigny, the jurisprudential concept of the positive is bound to a particular type of "source" protected by jurists. Law emerges from this "source" in a specific way, as something not merely legislated but given. The later positivism knows no origin and has no home. It recognizes only causes or basic norms. It seeks to be opposite of "unintended" law. Its ultimate goal is control and calculability. ${ }^{48}$

It is around these principles that Schmitt would organize his own work and thinking on how the European state system emerged and how it fell. As will be seen, the "source" that Schmitt speaks of is tied to a symbiosis between land and law, that is, to the nomos of the earth. This nomos is defined by a fundamental constituent act, that is, the appropriation of land (Landnahme). Without this unity between land and law, or as Schmitt refers to them between orientation and order, juridical concepts simply become free-floating signifiers that lack concrete meaning and tend towards the perceived nihilism of the modern age.

III Excursus: Some Perspectives on International Law Jurisprudence during the Inter-War Years

By no means was Schmitt alone in his critique of the emerging liberal perspectives of international law during the inter-war period. Beginning in 1929 , Morgenthau, in his doctoral dissertation, recognized the inherent limitations of establishing an international order through which the rule of law can properly adjudicate

\footnotetext{
${ }^{48}$ Schmitt, "The Plight of European Jurisprudence." p. 56-57
} 
"tensions" between states. ${ }^{49}$ The intensity of a political dispute between sovereign nations could no longer be reduced to a legally reasonable solution even with a judicial decision. The intense feelings felt by Germans towards the established positive law of the Versailles peace accord certainly cast doubt on the law's long-term observation and maintenance. The legal positive approach to international law, which consists of looking solely at the incorporated statutes through peace treaties and state court judgments, does in no way account for its sources, nor provide a thorough doctrine on the problem of rebus sic stantibus. ${ }^{50}$ In the case of the Versailles treaty, a legal positive approach could not have captured the essential "political" quality that revolved around the participants. That political quality, Morgenthau argued, was the reason why potentially noncontroversial matters (i.e., postal accords, trade accords, or, more generally, functional relationships between states) can suddenly become intensely conflictual. ${ }^{51}$ Morgenthau lamented the fact that during the inter-war period international jurors were "paying almost no attention to the psychological and sociological laws governing the actions of men in the international sphere. ${ }^{, 52}$ The increasing emphasis on the procedural and formal quality of interwar jurisprudence distracted from the growing political crisis in Europe at the time. Furthermore, as Morgenthau notes, there are observed rules of conduct that are

\footnotetext{
${ }^{49}$ Koskenniemi, The Gentle Civilizer of Nations: The Rise and Fall of International Law 1870-1960. p. 442

so The international law doctrine that foresees the possibility of one state discharging its obligation to another state because of a material change in the conditions that has the possibility of imperiling the existence of the state.

${ }^{51}$ Scheuerman, Carl Schmitt: The End of Law. pp. 226-227

52 Hans Joachim Morgenthau, "Positivism, Functionalism, and International Law," The American Journal of International Law 34, no. 2 (1940). p. 282; See also Koskenniemi, The Gentle Civilizer of Nations: The Rise and Fall of International Law 1870-1960. p. 459 and Hans Joachim Morgenthau, La Notion Du "Politique" : Et La Theorie Des Differends Internationaux (Paris: Recueil Sirey, 1933).
} 
not formalized with written statutes or treatises. ${ }^{53}$ Norms and practices, which have governed the European state system and the conduct of war, were, for the most part until the mid- $19^{\text {th }}$ century, not formalized written statutes. Ultimately, Morgenthau agreed with Schmitt that the liberal ideal of a formalization of international law could not factor in the inherent political necessities, necessarily sui generis and thus exceptional, that afflict the state within the international system. In a retrieval of Schmitt's decisionism, Morgenthau decided to locate the need for a decision-maker who could not be the international lawyer in the person of the statesman who can possess political "wisdom." 54

Certainly, a continuous and trenchant critique of the separation between politics and law can also be found in E.H. Carr's canonical work, The Twenty Years Crisis. ${ }^{55}$ Here, Carr argues that, "Politics and law are indissolubly intertwined" and that "Law, like politics, is a meeting place for ethics and power." of the sovereign that constitutes the binding property of law, and not a "personification of law." Carr cast doubt on the liberal appeals to the "rule of law" and "government of laws not of men." In a classic Schmittian phraseology, Carr writes: "Every system of law presupposes an initial political decision... as to the authority entitled to make and unmake law." ${ }^{57}$ Thus in the realm of international law, the personification of law in the form of

\footnotetext{
${ }^{53}$ Morgenthau, "Positivism, Functionalism, and International Law." pp. 265-266

${ }^{54}$ Hans Joachim Morgenthau, Scientific Man Vs. Power Politics (Chicago: University of Chicago Press, 1974). p. 120 Morgenthau writes: "The question to be answered is not what the law is but what it ought to be, and this question cannot be answered by the lawyer but only by the statesman. The choice is not between legality and illegality but between political wisdom and political stupidity."

${ }^{55}$ Edward Hallett Carr, The Twenty Years' Crisis, 1919-1939: An Introduction to the Study of International Relations (New York: Harpar Torchbooks, 1964).

${ }^{56}$ Ibid. pp. 177-178

${ }^{57}$ Ibid. p. 180
} 
appeals to the rule of law falls back onto the Hobbesian emphasis on the one who decides. Carr writes:

When modern writers on international politics find the highest moral good in the rule of law, we are equally entitles to ask, What law? And Whose law? The law is not an abstraction. It cannot be understood independently of the political foundation on which it rests and of the political which serves. ${ }^{58}$

In addition, Carr returned to the problem that Morgenthau grappled with concerning the judiciability of inter-state conflicts. Echoing both Morgenthau and Schmitt, Carr writes: "There is no principle of law which enables one to decide that a given issue is suitable for legal methods. The decision is political..."59 Carr points to the inherent inability of establishing a gapless foundation of international law for the purpose of resolving political disputes. At the national level, as Carr argues, a party to a conflict based on existing "legal rights" can either seek redress for a perceived wrong either through legal channels, the judiciary, or through political legislation. ${ }^{60}$ However, the international legal order is not amenable to resolving disputes, not only because it lacks the adequate "machinery" for devising impartial pronouncements on the legality of politically substantive questions, but more importantly, as Carr suggests, "because no responsible tribunal cares to commit itself on any important issue to an authoritative pronouncement as to what is 'equitable' or 'just' in international relations."

What Schmitt, Morgenthau and Carr all have in common is a critique of the persistent attempts at devising an international legal order that does not take into account

\footnotetext{
${ }^{58}$ Ibid. p. 179

${ }^{59}$ Ibid. p. 199

${ }^{60}$ Ibid. p. 202

${ }^{61}$ Ibid. p. 207
} 
the political. One of the reasons why international law and jurisprudence in the $20^{\text {th }}$ century have generally not wanted to integrate political questions within their fields of study is precisely because of the real possibility of reducing the positivist epistemology to polemical arguments. The formal legalistic approaches that have mostly characterized Anglo-French jurisprudence were attempts at devising "solutions" to the problem of war and peace through either the establishment of a universal legislature or a judiciary. ${ }^{62}$ One such work, though it should be said that it sought to distance itself from the reigning legal positivism of the times, was one of the canonical texts of international law during the interwar period. This work by Sir Hersch Lauterpacht, The Function of Law in the International Community, was concerned with establishing a gapless international law that would become a platform for establishing judicial procedures for the resolution of conflicts. ${ }^{63}$ Lauterpacht's "Victorian liberalism" translated itself into a profound faith in the reasonable progress of man through institutions such as the League of Nations, even though "their eclipse must be regarded as temporary and transient." ${ }^{, 64}$ The intrinsic lacunae in international law, such as those mentioned above concerning rebus sic stantibus, become tractable problems that are resolved when "international law [is]

\footnotetext{
${ }^{62}$ One of the famous French texts of that era was the work of George Scelle (1978-1961) who in Précis de Droit des Gens (v.1 \& 2) articulated a world in which a single legislature, with an enforcement "police" would regulate the international system. Scelle displaced the traditional state as the only recognized legal actor with the individual resulting in a legal monism, where law cannot be distinguished between the national or international levels. Consequently, humanitarian intervention naturally overrides national sovereignty and states could support individuals or social groups to rebel against the local authorities that are judged to be contravening international law. See Koskenniemi, The Gentle Civilizer of Nations: The Rise and Fall of International Law 1870-1960. pp. 327-342

${ }^{63}$ Hersch Lauterpacht, The Function of Law in the International Community (New York: Garland Publishing, 1973). Schmitt reviewed Lauterpacht's work at length in his 1938 essay Die Wendung zum Diskriminierenden Kriegsbegriff later translated as Schmitt, War/Non-War?: A Dilemma.

${ }^{64}$ Lauterpacht quoted in Koskenniemi, The Gentle Civilizer of Nations: The Rise and Fall of International Law 1870-1960. p. 358
} 
conditioned by its incorporation into general principles and a conception as developed by civilized communities without reference to the "state of nature existing among states.",65

What's more, Lauterpacht argues:

The notion of law, with the help of which the international lawyer gauges and determines the nature of the rules which form the subject matter of his science, is necessarily an $a$ priori one. But this is an additional reason why it should be construed on the basis of what is best and most developed in legal experience - not on the basis of emaciated, fragmentary, and historically questionable experience of primitive communities in past ages. It is of the essence of the dignity of legal science - including the science of international law - to resist the temptation to lower the standard of law to the low level of rudimentary practice. ${ }^{66}$

Lauterpacht's progressivist / legal constructivist approach to international law, which rests upon establishing a juridical structure powerful enough to govern contractual relations between states, is diametrically opposed to Schmitt's historically rooted approach. Schmitt chided Lauterpacht for not fully grappling with the problem of war within his juridical construction. ${ }^{67}$ Instead, war was viewed by Lauterpacht as a pathological state of affairs, a breach of the covenant between states, first articulated in Article 16 of the League of Nations charter, and something that ultimately needed to be eliminated through the application of the rule of law. ${ }^{68}$

\footnotetext{
${ }^{65}$ Lauterpacht, The Function of Law in the International Community. p. 432 my emphasis

${ }^{66}$ Ibid. p. 434 my emphasis

${ }^{67}$ Schmitt, War/Non-War?: A Dilemma.p. 37

${ }^{68}$ Ibid.; See also Koskenniemi, The Gentle Civilizer of Nations: The Rise and Fall of International Law, 1870-1960. p. 425; Article 16 of the League of Nations charter states:

Should any Member of the League resort to war in disregard of its covenants under Articles 12, 13 or 15, it shall, ipso facto, be deemed to have committed an act of war against all other Members of the League, which hereby undertake immediately to subject it to the severance of all trade or financial relations, the prohibition of all intercourse between their nationals and the nationals of the covenant-breaking State, and the prevention of all financial, commercial or personal intercourse between the nationals of the covenantbreaking State and the nationals of any other State, whether a Member of the League or not.

It shall be the duty of the Council in such case to recommend to the several Governments concerned what effective military, naval or air force the Members of the League shall severally contribute to the armed forces to be used to protect the covenants of the League.
} 
Schmitt's main text on international law, written for the most part during the Second World War, and later published in the 1950s in West Germany, represented the conceptual embodiment of his work on the subject of international order and jurisprudence. The historicity of Schmitt's work is based upon an examination of different global orders that have governed relations between peoples. The presence of the Greek word nomos and the German word Erde (or "Earth" in English translation) in the title of his treatise is indicative of Schmitt's desire to uncover the fundamental relationship that binds law and land. The word nomos itself has come to signify, through the Sophists, a set of laws or conventions that either originates in historical custom or is imposed by the authority of a ruler. ${ }^{69}$ Within Plato's original utopian political philosophy for the ideal polis, nomos became "a schedon - a mere rule...[that] contain[s] something of the utopian plan-character of modern laws." The "ought" of the norm or rule became associated with nomos while the "is" of social reality is juxtaposed through its binary opposition to phusis or nature. This binary opposition between nomos and phusis becomes responsible for a misleading antithesis that ultimately leads straight to modern

The Members of the League agree, further, that they will mutually support one another in the financial and economic measures which are taken under this Article, in order to minimize the loss and inconvenience resulting from the above measures, and that they will mutually support one another in resisting any special measures aimed at one of their number by the covenant-breaking State, and that they will take the necessary steps to afford passage through their territory to the forces of any of the Members of the League which are co-operating to protect the covenants of the League.

Any Member of the League which has violated any covenant of the League may be declared to be no longer a Member of the League by a vote of the Council concurred in by the Representatives of all the other Members of the League represented thereon.

${ }^{69}$ Richard Ned Lebow, The Tragic Vision of Politics: Ethics, Interests, and Orders (New York: Cambridge University Press, 2003). p. 141-142

${ }^{70}$ Schmitt, The Nomos of the Earth in the International Law of the Jus Publicum Europaeum. p. 67 
day normativism and legal positivism. ${ }^{71}$ By contrast, in an effort to combat the predominance of legal positivism, Schmitt's renewal of concrete order thinking is tied to an attempt at grounding the legal order in terms of "social groups, associations, and institutions" that comprise the social reality. ${ }^{72}$ Rather than considering law as an abstract universal norm or an immutable natural law discoverable through reason, Schmitt argues "For concrete-order thinking, [whereby] 'order' is also juristically not primarily 'rule' or a summation of rules, but conversely, rule is only a component of and a medium of order." In this case, nomos, Schmitt writes, "like 'law,' does not mean statute, rule, or norm, but rather Recht [as in the French Droit], which is norm, as well as decision and, above all, order." 73 A concrete order or nomos thus combines the decisionism of the Hobbesian sovereign with the institutional arrangements of a social order. In a sense, no longer do we see here the pure decisionism within his Political Theology, but rather we start to perceive an emphasis on a more Burkean or organic conception of the symbiosis between the institutional arrangements of the social order and the decision on the exception. To achieve such a symbiosis, it is necessary to understand how an order is physically localized in the first place. This is why Schmitt sought to reinvestigate the original meaning of nomos, not as mere rule, but as an order combining social order with localization.

To begin his inquiry into a different meaning of nomos, Schmitt sought to offer a philological argument for the etymology of the word. Rather than referring to mere

\footnotetext{
${ }^{71}$ Ibid. p. 70

${ }^{72}$ Carl Schmitt, On Three Types of Juristic Thought, trans. Joseph W. Bendersky (Westport: Praeger Publishers, 2004). p. 20

${ }^{73}$ Ibid. p. 48,50
} 
custom or regulation, Schmitt argued that the substantive nomos, as a noun, indicates an action or process defined through the verb neimen, which means, "to take", "to divide", and "to pasture." 74

Nomos is the measure by which the land in a particular order is divided and situated: it is also the form of political, social, and religious order determined by this process. Here, measure, order, and form constitute a spatially concrete unity. ${ }^{75}$

This dividing of "pastureland" is, for Schmitt, the original moment for nomos as a form of land-appropriation. The notion of a division of property as the constituting principle for law is also found in Hobbes, which is cited by Schmitt:

Seeing therefore the introduction of propriety is an effect of commonwealth, which can do nothing but by the person that represents it, it is an act only of the sovereign, and consisteth in the laws, which none can make which have not the sovereign power. And this they well knew of old, who called that nomos (that is to say, distribution) which we call law, and defined justice by distributing to every man his own. ${ }^{76}$

The establishment of a colony or the founding of a city constitutes an action whereby a people "becomes historically situated and turns a part of the earth's surface into a forcefield of a particular order..."77 This "force-field" or demarcation represents a "line" between the inside and outside of a spatial area. It is that delineation that forms the limit that defines the sovereign exception. For Schmitt then, nomos as an act of measurement represents the primordial political process, as an act of sovereignty that results in a spatial

\footnotetext{
${ }^{74}$ Schmitt, The Nomos of the Earth in the International Law of the Jus Publicum Europaeum. p. 70; See as well Carl Schmitt, "Appropriation/Distribution/Production: Toward a Proper Formulation of Basic Questions of Any Social and Economic Order," Telos, no. 95 (1993).

${ }^{75}$ Schmitt, The Nomos of the Earth in the International Law of the Jus Publicum Europaeum. p. 70 emphasis in the original

${ }^{76}$ Hobbes, Leviathan : With Selected Variants from the Latin Edition of 1668. Part II Chapter xxiv emphasis in the original; Quoted in Schmitt, "Appropriation/Distribution/Production: Toward a Proper Formulation of Basic Questions of Any Social and Economic Order." p. 55

${ }^{77}$ Schmitt, The Nomos of the Earth in the International Law of the Jus Publicum Europaeum. p. 70
} 
definition of inclusion and exclusion. The ability of any political order to delineate an inside and an outside is necessary for the maintenance of its own concrete order; the interiority of the political order is, by Schmitt's definition of the concept of sovereignty, a decision on the exception, although it places the sovereign in a paradoxical in-between position. What Agamben refers to as the paradox of the sovereign's locus is its ability to be inside and outside the juridical order at the same moment in time. Agamben continues by arguing that "The 'ordering of space'...constitutive of the sovereign nomos is therefore not only a 'taking of land'... but above all a 'taking of the outside,' an exception (Ausnahme). ${ }^{, 78}$ As will be seen, this has been the central process at work in the evolution towards to the Jus Publicum Europaeum precisely because this order was able to externalize the exception that the respublica Christiana failed to maintain.

This understanding of nomos is naturally tied to the earth itself and not the sea. As

Schmitt writes in a quasi-mythical appeal to mother earth:

In this way, the earth is bound to law in three ways. She contains law within herself, as a reward of labor; she manifests law upon herself, as fixed boundaries; and she sustains law above herself, as a public sign of order. Law is bound to the earth and related to the earth. $^{79}$

The terrestrial basis of land-appropriation is based upon the localization, or the orientation, of a particular territory that results in a primary legal claim. To appropriate land is necessarily to lay legal title to it. The very action of appropriating land, for Schmitt, signifies a primordial act of legitimacy that precedes the formation of law. As Schmitt argues, "in its original sense, however, nomos is precisely the full immediacy of

\footnotetext{
${ }^{78}$ Agamben, Homo Sacer: Sovereign Power and Bare Life. p. 19

${ }^{79}$ Schmitt, The Nomos of the Earth in the International Law of the Jus Publicum Europaeum. p. 42
} 
a legal power not mediated by laws; it is a constitutive historical event - an act of legitimacy, whereby the legality of a mere law is made meaningful." ${ }^{80}$ When Schmitt speaks of the "spatially concrete unity," he seeks to point out the unity between an order and orientation that gives rise to what later becomes a concrete order. It is this concrete order that becomes responsible for the meaning of norms and rules within its predefined spatial division. This unity between law and earth, as Schmitt expresses it, is fundamental to any conception of international law, as Schmitt understands it, because it becomes responsible for clearly articulating territorial boundaries.

In contrast to Schmitt's earlier writings on sovereignty, where the sovereign is the ultimate guarantor of legitimacy through the decision on the exception, Schmitt now isolates an original moment of land-appropriation as the foundation for all authority and order. This is in stark contrast to the sea that can have no "unity of space and law, or order and orientation," precisely because it cannot be appropriated and divided like the earth. ${ }^{81}$ The inability to define such a nomos on the ocean, Schmitt, argues, is emblematic of its inability to be clearly demarcated and divided: "The sea has no character, in the original sense of the word, which comes from the Greek charassein, meaning to engrave, to scratch, to imprint." 82

All preceding conceptions of international law can be articulated through this constitutive process of external land-appropriation between peoples. What forms the particular origin of an order has been the very process of appropriation and division of

\footnotetext{
${ }^{80}$ Ibid. p. 73

${ }^{81}$ Ibid.

${ }^{82}$ Ibid. p. 43
} 
land. The basis and foundation of the medieval legal order originated with the landappropriation of the Germanic peoples throughout the Western Roman Empire. Though this resulted in a fractioning of the unity of the Roman Empire, Europe remained under a concrete order through the unity of the Christian faith. The evolution of the respublica Christiana revolved around an order and orientation that delimited an inside and an outside. The source of its nomos was in differentiating the outside, which comprised lands not controlled by Christian princes (for example, lands controlled by Muslims), and the inside which comprised of Christian princes under the spiritual rule of the Catholic Church. Schmitt describes the significance of this epoch by its ability to differentiate conflict precisely along this line of inside and outside:

The essential point is that, within the Christian sphere, wars among Christian princes were bracketed wars. They were distinguished from wars against non-Christian princes and peoples. These internal, bracketed wars did not negate the unity of the respublica Christiana. They were feuds in the sense of assertions of right, realizations of right, or confirmations of a right of resistance, and they occurred within the framework of one and the same total order encompassing both warring parties. This means they did not abolish or negate the total order. ${ }^{83}$

However, wars against non-Christian lands were always considered just wars. Through the benediction of Popes, these wars were even taken to be holy crusades. Foreign lands could legally be appropriated at will without any form of legal justification. The crusades can be considered a medieval form of land-appropriation that sought to confer an act of legitimacy in the name of the unity of the Catholic faith. In terms of the interior orientation and order of the medieval political world, what properly constituted it as a concrete order was its "orientation to Rome." However, as Schmitt makes it clear, this orientation should not be considered eternal. In view of Christian eschatological

${ }^{83}$ Ibid. p. 58-59 
theology, however, the respublica Christiana was considered a momentary occurrence

that would dissolve with the coming of the Last Judgment. Schmitt describes a unique

biblical concept that worked for the strengthening of this Christian "empire" as a way of

preserving and restraining this eschatological dread. The concept of the Katechon, taken

from the book of Thessalonians in the New Testament, is described as a restrainer against

the coming of the Anti-Christ. ${ }^{84}$ The strengthening of the institutions of the church,

Schmitt describes, becomes associated with this notion of Katechon that forestalls the

collapse of the concrete order. ${ }^{85}$

${ }^{84}$ Ibid. p. 60 Schmitt writes: "I do not believe that any historical concept other than the katechon would have been possible for the original Christian faith. The belief that a restrainer holds back the end of the world provides the only bridge between the notion of an eschatological paralysis of all human events and a tremendous historical monolith like that of the Christian empire of the Germanic kings."

${ }^{85}$ Ibid. p. 64; It is this idiosyncratic usage of the biblical Katechon by Schmitt that many commentators have used to describe Schmitt's motives as being wedded to a certain political theology. Heinrich Meier's interpretation of Schmitt's use of the Katechon is the most vocal in this regard. For one, Meier refers to the Katechon as a restrainer first and foremost against any ideas related to an "end of history" and as a proper retrieval of a Christian interpretation of history. In this light, Meier comments on Schmitt's interpretation of Karl Löwith's book Meaning in History. Löwith's central thesis, it should be recalled, stipulated that enlightenment notions of progress, and more generally unidirectional concepts of time, embodied in philosophies of history are nothing more than a secularization of Judeo-Christian eschatology. Meier points to Schmitt's review of Löwith's book as a demonstration of Schmitt's own ultimate view of Christian history by quoting him: "In its essential core Christendom is not a morality and not a doctrine, not a sermon calling to repentance and not a religion in the sense of comparative religious studies, but rather a historical event of infinite, unpossessable, unoccupiable uniqueness." The essential uniqueness of Christendom, Meier argues, is Schmitt's own affirmation of the transcendent quality of faith that defies any attempt at neutralization inherent in modern notions of historicism. Meier goes on to explain that: "The faith in the Katechon helps Schmitt to preserve his faith in the truth of revelation and to remain in harmony with himself." For Meier, Schmitt's ultimate usage of the Katechon in the modern age embodies the restraining force against the emergence of a world state where politics becomes subsumed into bourgeois liberal life. In the end Meier argues that for Schmitt, "salvation is, in opposition to all concepts, the decisive meaning of all world history." Meier, The Lesson of Carl Schmitt: Four Chapters on the Distinction between Political Theology and Political Philosophy. pp. 158-173 and Löwith, Meaning in History. What should be remembered, as was argued in the first chapter, was Schmitt's continuous and unflinching perception that the modern age, embodied in the liberal-bourgeois world represents a nihilistic form of universalism. In a similar conclusion to Meier, Martti Koskenniemi argues that Schmitt's world-historical view in The Nomos of the Earth, amounts to a "worldly conflict in terms of the struggle between Christ and Anti-Christ which marks the persistence of historical time until, finally, 'Babylonian' world unity will be attained with the victory on earth of the latter, and in the end of historical time. The meaning of history from this perspective is not 'progress' or unity, but salvation." Koskenniemi, "International Law as Political Theology: How to Read Nomos Der Erde?." p. 501; On the other hand, Wolfgang Palaver argues that Schmitt's theory of international relations, though based on a political theology of the Katechon as a restrainer against world unity, focuses instead on its ability to allow for an anarchic structure. Palaver quotes Schmitt as writing, "anarchic chaos is better than nihilistic centralization. One can recognize the Katechon by the fact that he does not strive for world-unity." Palaver goes on to argue: "Schmitt's siding with Rome, his insistence on the justice of mother earth, is not rooted in Christian theology but in paganism. Mythic paganism is also 
Significantly, the dissolution of the medieval unity, Schmitt argues, was specifically related to the diminishing awareness of the place of the Katechon in medieval jurisprudence. Schmitt continues by suggesting that the "adoption of the concepts of corpus juris [body of laws] also had a destructive, disorientating effect, and they did not have the power to consecrate Rome anew. In the constructions of the $14^{\text {th }}$ and $15^{\text {th }}$ century jurists of Roman law, the link between Christian empire and territorial monarchy that served to uphold the work of the Katechon had been forgotten." ${ }^{, 86}$

The collapse of the medieval Christian concrete order through the reformation and the subsequent civil wars would bring about a total re-conceptualization of spatial concepts and of the unity of order and orientation. The emerging new order was not based on the hierarchical unity "orientated towards Rome," but rather on a spatial division delineated by a concept of non-intervention through the creation of territorial boundaries.

\footnotetext{
visible where Schmitt quoted Hölderlin's polytheistic poem as a confirmation of hope in a new pluralistic nomos of the earth. From the perspective of mimetic theory, it is clear that Schmitt's way of thinking contradicts the biblical spirit. His particular anti-Semitism turns out to be ultimately an enmity against the Judeo-Christian bible." Palaver, "Carl Schmitt on Nomos and Space." p. 124; In which case, Palaver argues against the previous readings of Schmitt's project as desiring a Judeo-Christian universalism that finds its end in a form of salvation. Rather, as will be seen in the next chapter, Schmitt's own emphasis in establishing a new nomos of the earth through a set of Grossraum [large spaces] that continuously conflict with each other, points to Schmitt's own desire to see a continuation of the political. Thus, the only way to read Schmitt, in my view, as a theologian desiring a form of salvation is to make the argument that only through a continuation of conflict can the authentic identity of the self emerge. Salvation then is not an end in itself, but the continuous manifestation of resoluteness in political struggle. ${ }^{86}$ Schmitt, The Nomos of the Earth in the International Law of the Jus Publicum Europaeum. p. 64 Schmitt
continues on the next page: "However, as already noted, once (beginning in the $13^{\text {th }}$ century) political units
were formed that not only factually, but increasingly also legally withdrew from the Imperium and sought
to restrict the auctoritas of the sacerdotium to purely spiritual matters, the medieval Christian order began
to dissolve." For this Schmitt blames Bartolous of Saxoferrato (1314-57). For a more in depth treatment of
the role of Bartolous of Saxoferrato his influence within the conflict between the Italian city states and with
the Holy Roman Empire and Papacy see for example Quentin Skinner, The Foundations of Modern
Political Thought (Cambridge: Cambridge University Press, 1978).; The relationship between Roman law
and its subsequent integration into late medieval jurisprudence is something that Schmitt polemicizes
against. In an earlier quoted essay, Schmitt makes the argument that Roman law, over time, leads to the
abstract normativism inherent in legal positivism and the "mechanization" of law. See Schmitt, "The Plight
of European Jurisprudence."
} 
This point becomes crucial in subsequently understanding Schmitt's arguments on how the ensuing Jus Publicum Europaeum maintained itself.

Nonetheless, the stability of this new division was not based on a transcendent conception of Right that mediated the secular relationships between princes through the offices of the Pope. As Schmitt writes, "the new spatial order no longer was grounded in a secure orientation, but rather in a balance, an "equilibrium." 87 The consequence of such a profound shift was, as well, a transformation of the concept of war from its connection to previous notions of justifiability to its becoming and intrinsic right of every recognized sovereign. This would have profound repercussions on how international law would develop in the modern era. As Schmitt argues:

Every order of international law must guarantee, if it does not disavow itself, not the given territorial status quo of a particular historical moment, with all its many details and more less contingent circumstances, but rather its fundamental nomos - its spatial structure, the unity of order and orientation. Thereby, it is not only possible but often even necessary to recognize wars, feuds, reprisals, and applications of force of various kinds as a means of effecting changes. However these methods and procedures are bracketed; they do not jeopardize the comprehensive spatial order as a whole. War does not disturb this order. But certain damaging and destructive methods and goals of pursuing war disturb the traditional bracketing of war. ${ }^{88}$

This ability to conceive of an order that is able to bracket war, Schmitt argues, was in large part due to the unique occurrence of an extra-European land appropriation that began in the new world. What emerged was a clear distinction between the inside

${ }^{87}$ Schmitt, The Nomos of the Earth in the International Law of the Jus Publicum Europaeum. p. 66; Schmitt makes it clear that he does not see the anarchic events following the breakdown of the respublica Christiana as a degeneration into a nihilistic world-view. He continues on the same page: 'Until then, there had been tumultuous conditions of a terrible sort, also on European soil - conditions of 'anarchy,' but not of 'nihilism' in the sense of the $19^{\text {th }}$ and $20^{\text {th }}$ centuries. If 'nihilism' is not to become an empty phrase, one must comprehend the specific negativity whereby it obtains its historical place: its topos. Only in this way can the nihilism of the $19^{\text {th }}$ and $20^{\text {th }}$ centuries be distinguished from the anarchistic conditions of the Christian Middle Ages. In the connection between utopia and nihilism, it becomes apparent that only a conclusive and fundamental separation of order and orientation can be called 'nihilism' in an historically specific sense." Utopia, it should be remembered, signifies to be "without space."

${ }^{88}$ Ibid. p. 186 
and the outside of the Jus Publicum Europaeum. While the inside followed an institutionalized ordering for bracketed conflicts to play out, the outside was subject to an initially free "land-appropriation" among European states. The inside was even considered part of a community of sovereigns that respected certain rules of conduct. In this configuration, the interiority of the Jus Publicum Europaeum was not strictly a Hobbesian state of nature; that instead became the domain of the new world. The discovery of the new world became open for the wholesale occupation by the European states. ${ }^{89}$ Schmitt describes the emergence of a new form of "global linear thinking" that established for the first time a global of delineation lands outside Europe. ${ }^{90}$ The first of these geographic lines to appear were the Spanish rayas. This boundary condition, established by two parties under the same religious authority, demarcated a zone of territory that was free for exploration and missionary expeditions. These lines were first and foremost delimitations agreed upon by Christian princes based on their respective rights of exploration. The most famous example of these rayas was the SpanishPortuguese division of the new world by the Treaty of Tordesillas. ${ }^{91}$ However, as Schmitt notes, "in practice, areas free for missions were not separated from those of navigation and trade," and navigation and trade would eventually lead to outright occupation. $^{92}$

\footnotetext{
${ }^{89}$ Ibid. p. 130

${ }^{90}$ Ibid. p. 93

91 The Treaty of Tordesillas was established by a decree of Pope Alexander VI which stipulated an imaginary line running from north to south $400 \mathrm{~km}$ from the Cape Verde Islands where Spain would possess all unclaimed lands to the west of the line while Portugal would have the same right to the east.

${ }^{92}$ Schmitt, The Nomos of the Earth in the International Law of the Jus Publicum Europaeum. p. 91
} 
With the coming of the reformation, the European civil wars, and the division between Catholic land powers and Protestant sea powers, a new concept emerged, that of the amity line. The amity line first appeared in a secret clause of the Cateau-Cambrésis treaty of 1559 . These amity lines, unlike the rayas, were not developed under a unified papal authority. Rather they were ad hoc agreements between parties. Geographically they usually followed the lines of the equator or tropic of cancer and the meridians passing through the Azores and Canary Islands. ${ }^{93}$ Outside of these lines, the Jus Publicum Europaeum ended and the "bracketing of war" turned into a ruthless pursuit of territory and piracy resembling a Hobbesian state of nature. As Schmitt writes:

\begin{abstract}
At this 'line,' Europe ended and the 'New World' began. At any rate, European law, i.e. 'European Public law,' ended here. Consequently, so, too, did the bracketing of war achieved by traditional European international law, meaning that here the struggle for land-appropriation knew no bounds. Beyond the line was an 'overseas' zone in which, for want of any legal limits to war, only the law of the stronger applied. The characteristic feature of amity lines consisted in that, different from rayas, they defined a sphere of conflict between contractual parties seeking to appropriate land, precisely because they lacked any common presupposition and authority....But the only matter they could agree on was the freedom of the open spaces that began 'beyond the line'...Everything that occurred 'beyond the line' remained outside the legal, moral, and political values recognized on this side of the line. This was a tremendous exoneration of the internal European problematic. The significance in international of the famous and notorious expression 'beyond the line' lies precisely in this exoneration. ${ }^{94}$
\end{abstract}

From the treaty of Westphalia to that of Utrecht in 1713 , international conflict would become an affair between sovereign princes endowed with the sole right to make war. As mentioned above, this was made possible by reestablishing a new set of spatial concepts that united law defined by a new nomos of the earth. As Schmitt writes: "the core of this nomos lay in the division of European soil into state territories with firm

\footnotetext{
${ }^{93}$ Ibid. p. 93

${ }^{94}$ Ibid. p. 93-94 emphasis in the original
} 
borders, which immediately initiated an important distinction, namely that this soil of recognized European states and their land had special territorial status in international law." $" 95$ The aims of war, then, would change to reflect a more limited and rational orientation. Territory was prized over the pursuit of justice. Thus no one could claim a divine mandate for the fulfillment of a just cause. As Schmitt wrote in his treatise on Hobbes:

In contrast to religious, civil, and factional wars, wars between states cannot be measured with the yardsticks of truth and justice. War between states is neither just nor unjust; it is an affair of state and as such does not have to be just... The state has its order in, not outside itself. What is therefore essential to international law...is law that does not distinguish between just and unjust, a nondiscriminating concept of war. War between states derives its dignity and its honor and hence also its right from the fact that states wage wars only against states and that only states can face one another as enemies. ${ }^{96}$

Inter-state European conflict would take the form of une guerre en forme, or, as Schmitt describes it, a conflict analogous to a duel between sovereigns now considered equals [personae publicae]. ${ }^{97}$ Only these sovereigns possessed the right to declare war, a fundamental right that was given to every recognized monarch without any normative precondition. Any sovereign could decide to initiate war without fearing being branded an aggressor. The Jus Publicum Europaeum thus became responsible for the "bracketing" of war with the emergence of the justus hostis [just enemy] as opposed to the medieval

\footnotetext{
${ }^{95}$ Ibid. p. 148

96 Schmitt, The Leviathan in the State Theory of Thomas Hobbes: Meaning and Failure of a Political Symbol.p. $47-48$

${ }^{97}$ Schmitt, The Nomos of the Earth in the International Law of the Jus Publicum Europaeum. p. 141 An interesting passage as well is on page 146 where Schmitt writes: "For example, one such secondary question is the dispute about whether one should think of these 'great men' as existing in a 'state of nature' beyond an amity line and, in turn, should consider this state of nature (in the sense of Hobbes) to be an asocial struggle of leviathans, or (in the sense of Locke) already to be in a social community of thoroughly proper gentlemen, or whether on should regard relations among these great men ostensibly in terms of statue law more analogous to a societas based on civil law, or in terms of a communitas based on civil law." For Schmitt the primary issue lies in the emergence of a "personalization of territorial states" that allowed for the emergence of an actual conception of jurisprudence of "interstate jus inter gens."
} 
conceptualization of the justus belli $\left[\right.$ just war]..$^{98}$ States could always be distinguished from criminals that usurped the right to commit violence for their own ends. While the medieval conceptualization of just cause would eventually lead to the criminalization of the enemy and to the legitimate pursuit of his annihilation, the subsequent establishment of territorially grounded sovereigns, along strictly defined boundary alignments, would "signify the highest rationalization and humanization of war." 99 The avoidance of a total "intensification of conflict" could only occur "when the opponent is recognized as an enemy on equal grounds..." Thus, "the singular achievement of international law was not the elimination, but the bracketing of war." 100 The bracketing of war allowed for an essential "preservation of the form." 101 That is, conflict between princes did not destabilize the set of grounded principles that dictated conduct. The concrete orientation and ordering of the European public order was robust enough to handle rivalries between states. Even the Seven Years War that was considered a quasi-world war did not cause the collapse of this order because the enemy was not viewed as the total enemy or foe. Neutrality was consistently observed and neutral parties were considered "impartial observers," in so far as "men of honor have found a satisfactory means of dealing with a matter of honor in a prescribed form" before these neutral parties. ${ }^{102}$

\footnotetext{
${ }^{98}$ Ibid. p. 187

${ }^{99}$ Ibid. p. 142

${ }^{100}$ Ibid.

${ }^{101}$ Ibid. p. 143

102 Ibid.; Some have taken issue with Schmitt's characterization of the Jus Publicum Europaeum as a humanization of conflict. For example, William Scheuerman argues that Schmitt downplays the fact that war at the highpoint of the European public order was by no bloodless affair. He points to the losses of the Seven years war that Prussia experienced as almost catastrophic. William E. Scheuerman, "International Law as Historical Myth," Constellations 11, no. 4 (2004). p. 544; However, Scheuerman misses Schmitt's
} 
Here we may make an important observation. Schmitt's central thesis is to demonstrate the ability of the European public order to limit and humanize war. He celebrates the transformation of war from the medieval notions of just war to a more limited and "rational" motivation that recognizes the equality of sovereigns within Europe. All of this points to an inherent humanist conception on the value of human life within Schmitt's work. Why else would he spend so much time, beginning with The Concept of the Political, decrying the modern era's drastic intensification of conflict to total war? As William Scheuerman points out, "Schmitt's apparent outrage against the murderousness of recent international politics implicitly presupposes characteristically modern norms of universal equality and reciprocity."103 We should recall Strauss's observation that Schmitt remains firmly within the liberal framework that he sought to fundamentally critique and which reflects a certain aporia present in Schmitt. This aporia finds itself in Schmitt's own ambiguity in conceptualizing the place of subjectivity in his political theory. On the one hand, he holds Hobbes responsible for allowing a subjectivity of "free conscious" that eventually, through Spinoza, neutralizes the power of the state. ${ }^{104}$ On the other, his position on liberalism's individualism manifests itself through his polemics against political romanticism.

important point that though the wars between European states were costly, they were not ultimately unbracketed total wars of the late medieval or $20^{\text {th }}$ century types. They were self-contained affairs between princes in which non-combatants were spared the most gruesome aspect of it.

${ }^{103}$ Scheuerman, "International Law as Historical Myth." p. 538

${ }^{104}$ For example Schmitt's student Reinhardt Koselleck writes "The State created a new order, but then - in genuinely historic fashion - fell prey to that order. As evident in Hobbes, the moral inner space that had been excised from the State and reserved for man as a human being meant (even rudimentary) a source of unrest. The authority of conscience remained and unconquered remnant of the state of nature, protruded into the formally perfected state." Koselleck, Critique and Crisis: Enlightenment and the Pathogenesis of Modern Society. pp. 38-39 Quoted in McCormick, "Fear, Technology, and the State: Carl Schmitt, Leo Strauss and the Revival of Hobbes in Weimar and National Socialist Germany." p. 638 
The nostalgia present in The Nomos of the Earth for a traditional European public order that eschewed universal appeals to justice is clearly present. Indeed, this nostalgia for a classical ordering of international politics is found in many classical realist scholars' writings, such as those by Hans J. Morgenthau or Henry Kissinger. ${ }^{105}$ The Jus Publicum Europaeum represented a time, for Schmitt, when the moral claims to justice became divorced from the legality of war itself. ${ }^{106}$ Nevertheless, the stability of this order being made contingent upon the ruthless pursuit of exterior territories in the new world is by no means unproblematic. Juan Gines Sepulveda famously argued that the native inhabitants of the new world were barbarians and cannibals. They were thus to be considered outside natural law. Following Aristotle, Sepulveda argued that the "barbarian is by "nature a slave'." Hence his lands should be free for occupation and appropriation. ${ }^{107}$ Schmitt recognized the inherent inhumanity towards the native inhabitants that resulted from devising distinctions between human and non-human. He utilized the writings of the Spanish theologian and jurist Francisco de Vitoria, on the one hand, as a way of demonstrating the gradual juridical movement to establishing a concept of justus hostis, and on the other, as a way of, accepting the inherent humanity of all inhabitants in the new world. ${ }^{108}$ Schmitt is by no means an apologist for the crimes committed during the

\footnotetext{
${ }^{105}$ Hans Joachim Morgenthau, Politics among Nations: The Struggle for Power and Peace, ed. Kenneth W. Thompson, 6th ed. (New York: Knopf : Distributed by Random House, 1985). Henry Kissinger, $A$ World Restored; Metternich, Castlereagh, and the Problems of Peace, 1812-22 (Boston,: Houghton Mifflin, 1973).

106 Hauke Brunkhorst, "The Right to War: Hegemonial Geopolitics or Civic Constitutionalism?," Constellations 11, no. 4 (2004). p. 513-514

${ }^{107}$ Schmitt, The Nomos of the Earth in the International Law of the Jus Publicum Europaeum. p. 102-103

${ }^{108}$ See as well Anthony Pagden, The Fall of Natural Man : The American Indian and the Origins of Comparative Ethnologv (Cambridge: Cambridge University Press, 1986).
} 
great conquistas. He explicitly refers to the practices in the new world as atrocities and barbarism. ${ }^{109}$ Similarly, while the $19^{\text {th }}$ century notion of civilization's superiority was displayed, for example, in Hegel's writings on other cultures, Schmitt described these views as exhibiting "the self-conscious arrogance of an idealist philosophy of history."110 Nonetheless, the linkage between a homogenous Eurocentric concrete order, and its selfmandated right to discover, occupy, plunder, and exploit foreign or "non-civilized" lands is highly disconcerting. It represents a moment in time when the full force of a tragic dilemma manifests itself: the stability of European order through the bracketing of war was conditional upon establishing a state of nature "beyond the line." Here, Raymond Aron's criticism of this state of affairs is acute. In a letter to Schmitt, Aron writes:

You keep nostalgia for the public European law where the state establishes internal peace, solely determining the external enemy...But even in terms of your own philosophy, European public law was nothing but and could have been nothing but an admirable, but precarious work of art. To use my language, the European system had to be homogenous...these sociological conditions require a conjunction rare and transitory. 111

The conjunction of events that found their realization in the highpoint of the Jus Publicum Europaeum could simply not last an eternity. There could not be an infinite appropriation of land. Once the European land-appropriation came to an end, the forces that propelled it would turn on themselves. At that moment, the lines between inside/outside became blurred to the point of indistinction, and slowly but surely we

\footnotetext{
${ }^{109}$ Schmitt, The Nomos of the Earth in the International Law of the Jus Publicum Europaeum. p. 103 ${ }^{110}$ Ibid. p. 108

${ }^{111}$ Quoted in Müller, A Dangerous Mind: Carl Schmitt in Post-War European Thought. p. 100
} 
arrive at the liberal economic notions of "one world." The next section will identify Schmitt's own explanation for the collapse of this concrete order.

\section{The Fall of the Jus Publicum Europaeum}

As was noted above, the fall of the European public order is in the first part attributable to a fundamental inconsistency between concepts of sea warfare and land warfare originating with the rise of maritime England. With the rise of the United States in the $19^{\text {th }}$ century as a global power, the traditional relationship between law and space would again break apart. Instead of this European relationship between land and space was a growing confidence in the economic order. This economic order was built on the premise that a mutual harmony of interests would emerge that would ground the new international order. The American and English sea powers would become the champions of an economic imperialism that would claim universal jurisdiction in the form of freedom of trade and intervention. In 1823, for example, the United States announced to the world, through the Monroe Doctrine, the closing off of the Western hemisphere to the European powers for the purpose of colonial appropriation. This in itself was a revolutionary juridical endeavor that asserted for the United States a special zone of influence over a large space. Schmitt himself admired such a construction precisely because it was grounded in a spatial ordering, in the form of an amity line, though one geared towards exclusion rather than a free competition for land. ${ }^{112}$ As he wrote in 1941, "this is the core of the great original Monroe Doctrine, a genuine Grossraum principle, namely the union of a politically-awakened people, a political idea and, on the basis of

112 G. L. Ulmen, "American Imperialism and International Law: Carl Schmitt on the Us in World Affairs," Telos 72 (1987). p. 51 
this idea, a politically dominant Grossraum excluding foreign intervention." ${ }^{113}$ However, this defensive spatial structure would not remain as such. Instead, the conjunction of worldwide economic interests intersected with a new messianic moral appeal that would transform the Monroe doctrine into a self-righteous claim for US intervention. These interventions would be treated as "police" actions in cases where either direct economic interest was at stake or for the sake of liberating an oppressed people. ${ }^{114}$ Explicitly, the Roosevelt Doctrine of 1904, for example, made the case for such "police" styled interventions:

Chronic wrongdoing...may in America, as elsewhere, ultimately require intervention by some civilized nation, and in the western hemisphere the adherence to the Monroe Doctrine may force the United States, however reluctantly, in flagrant cases of such wrongdoing or impotence, to the exercise of an international police power. ${ }^{115}$

In a similar development, Schmitt saw the freedom of exterior land-appropriation ending with the Congo Conference of $1885 .{ }^{116}$ It would be at this conference that the United States would begin to throw doubt upon the distinct dichotomy between what was considered a state and what was colony. ${ }^{117}$ By recognizing the flag of the International Congo Society on April 22, 1884, the United States staked a claim that overseas colonies could be accorded the sovereign rights granted within the framework of European

${ }^{113}$ Quoted in Ibid.

${ }^{114}$ The most obvious case was the US intervention in the Philippines starting in 1899 after its defeat of the Spanish in the Spanish American war.

${ }^{115}$ Ulmen, "American Imperialism and International Law: Carl Schmitt on the Us in World Affairs." p. 59

${ }^{116}$ Schmitt, The Nomos of the Earth in the International Law of the Jus Publicum Europaeum. p. 214; The Congo Conference culminating in the Berlin Act of 1885 was participated by all major European powers for the sake of determining the legal rights of appropriating land in Africa. More specifically, it granted all powers free access to trade in the Congo basin.

${ }^{117}$ Ibid. p. 217 
international law. ${ }^{118}$ At that moment, the fundamental unity between order and orientation of the Jus Publicum Europaeum came to an end.

However, Schmitt neglected the fundamental impact of the French revolutionary wars on the European state system. The emergence of a revolutionary France and its call for a levée en masse against the enemies of the revolution also changed the perception of what was at stake in war. At that time, no longer was the discernment of conflict based on the duel, but rather on an existential struggle that required total mobilization. Schmitt's student, Reinhardt Koselleck, locates the genesis of 20th century existential and ideological struggles in a fateful confluence between "progressive" philosophies of history and a moralizing critique of the absolutist state that originally found its culmination in the terror of revolutionary France. ${ }^{119}$ The attempts to contain the energies unleashed in the revolutionary wars at the Congress of Vienna in 1815 only delayed the inevitable decline of the European public order. The stability of post-Napoleon Europe was due in part to the last great land-appropriation in Africa. It would come to an end, as noted above, in the late 1890's with the ambiguous status of certain colonies and with the US push for recognition of colonies as legitimate actors on the world stage.

\footnotetext{
${ }^{118}$ Ibid.

${ }^{119}$ Koselleck, Critique and Crisis: Enlightenment and the Pathogenesis of Modern Society. Koselleck's remarks on the consequences of this nexus between a philosophy of progress and the moralization of the political is entirely reminiscent of Schmitt's own in The Concept of the Political: "Once the prince is deposed, the humanitarian battle position, politically speaking, becomes so insignificant and so variable that with the appeal to the man, a political enemy can be put on the defensive by labeling him a monster. Moral dualism, that the political expression of the indirect assumption of power, which in the eighteenth century could still be used by one camp in all good conscience of political innocence, afterwards becomes the weapons of all parties. The dualism of morality and politics, the intellectual weapon that helped bring on the Revolution, subsequently turned into the dialectical reality of the civil war itself; its staying power can be gathered from the almost inevitable employment of ostensibly moral categories for political purposes. In using the weapons appropriate to the eighteenth century, all parities became the victim of a mutually intensifying and compulsory resort to ideology which has characterized the modern age ever since." p. 151
} 
Nonetheless, the product of introducing these ambiguities, states versus colonies, in international law would later prove to be problematic in maintaining the traditional norms of the European concrete order insofar as the integration of more and more recognized states would begin to dissolve its structure. ${ }^{120}$ What followed this long process of dissolution was a turn to a universalized conception of international law. No longer were the norms of international law derived through a concrete spatial order. Rather they would be "nothing more than a series of generalizations of doubtful precedent, most based on transitory or heterogeneous situations, combined with more or less generally recognized norms, which, the more generally and more spiritedly they were 'recognized,' the more contested was their application in the concretely disputed case."121 It was this new abstractness of international law, and consequently, a devaluation of international jurisprudence that allowed a form of universal yet nihilistic - in that the universal values become simply a matter of how status quo powers define them - thinking to replace the concrete nomos of the earth. As Schmitt solemnly writes:

Silete theologi in munere alieno! So said humanistic jurists to theologians at the end of the $16^{\text {th }}$ century, in order to establish an independent jurisprudence of jus gentium. Three hundred years later, at the end of the $19^{\text {th }}$ century, jurisprudence, in the name of legal positivism, chose to remain silent with respect to all great contemporaneous issues. Sileamus in munere alieno! [We must remain silent in foreign walls.] With this rejection of international law, Europe stumbled into a world war that dethroned the old world from the center of the earth and destroyed the bracketing of war it had created. ${ }^{122}$

${ }^{120}$ Schmitt, The Nomos of the Earth in the International Law of the Jus Publicum Europaeum. p. 234 Schmitt writes "What appeared in its place was no 'system' of states, but a collection of states randomly joined together by factual relations - a disorganized mass of more than 50 heterogeneous states, lacking any spatial or spiritual consciousness of what they once had in common, a chaos of reputedly equal and equally sovereign states and their dispersed possessions, in which a common bracketing of war no longer was feasible, and for which not even the concept of 'civilization' could provide any concrete homogeneity."
${ }^{121}$ lbid. p. 238
${ }^{122}$ Ibid. p. 239 
The more ominous consequence of the lack of grounded nomos was the inability to define a set of spatially centered juridical concepts that could bracket wars. This inability, as noted earlier, would revolve around the inadequacy of universal abstractions to properly delineate a "line" between the norm and the exception. As Jan-Werner Müller argues, "the new world order clearly failed to externalize the exception - instead internalizing a potential permanent state of exception." ${ }^{123}$ That internalization of the state of exception, according to Agamben, led straight to a no-place, that of the concentration camp: "The camp is the space that is opened when the state of exception begins to become the rule." 124 Echoing Schmitt, Agamben continues:

The process (which Schmitt carefully described and which we are still living) that began to become apparent in the First World War, through the constitutive link between the localization and ordering of the old nomos was broken and the entire system of reciprocal limitations and rules of the ius Publicum Europaeum brought to ruin, has its hidden ground in the sovereign exception. What happened and is still happening before our eyes is that the "juridically empty" space of the state of exception...has transgressed its spatiotemporal boundaries and now, overflowing outside them, is starting to coincide with the normal order, in which everything again becomes possible. ${ }^{125}$

How does this affect international order and international law? Why are current approaches toward international order and law seen in such figures as Rawls and Habermas ultimately inadequate? Where is the inside and outside in today's world order and is there a way to reestablish a concrete nomos whose goal is not the elimination of war but rather its bracketing? These questions are what will be explored in the next chapter.

\footnotetext{
${ }^{123}$ Müller, A Dangerous Mind: Carl Schmitt in Post-War European Thought. p. 90

${ }^{124}$ Agamben, Homo Sacer: Sovereign Power and Bare Life. pp. 168-169 emphasis in the original ${ }^{125}$ Ibid. pp. 37-38
} 


\section{Finding the New Nomos of the Earth}

\section{Introduction}

It was shown in the second chapter that Schmitt conceptualized a tripartite unity between law, order, and place. That unity, established at the constituent moment of landappropriation, forms a concrete nomos, which subsequently creates the contours of the legal and political order. The establishment of the concrete order is necessarily the construction of a territorial boundary that designates an inside and an outside of the polity. By speaking of a nomos of the earth, Schmitt globalized this understanding of concrete order by looking at the various historical developments that created a "line" between the concrete applicability of interstate norms and a region where the exceptional situation prevails. The highpoint of the European public order, as a concrete order that bracketed war between equally recognized sovereigns, was reliant upon designating a space of free land appropriation in the new world. While the medieval order disintegrated through the religious civil wars, the highpoint of western rationalism seen in the Jus Publicum Europaeum could not reconcile two major occurrences. The first was simply that the European powers ran out of free land to appropriate. The second, the emergence of the United States and the pronouncement of the Monroe doctrine in 1823, forever closed off the western hemisphere to the European powers. Africa remained the last domain for free appropriation, though towards the late $19^{\text {th }}$ century the legal status of colonial possessions there began to be called - by the US among others - into question. The result was that progressively the line that divided the European concrete order from the rest of the globe began to blur into indistinction. 
This blurring of the lines was also caused, as Schmitt explains, by the rise of two maritime powers, Britain and, later, the United States, which consistently sought to remain at the fringes of the European concrete order; neither were they fully part of it nor were they completely outside. ${ }^{1}$ Instead, as Schmitt explained, their growing emphasis on economic relationships that prized open markets, free trade, and economic utilitarianism, called into question the traditional territorial boundaries that guided reasons of state. This logic of liberal economic interaction ("as much trade as possible, as little politics as possible") was perceived as being able to attenuate political conflict and, it was hoped, to eventually transcend them into technical "issues."2 Particularly, Schmitt notes that "The United States believed it could turn the political into an external façade of territorial borders, that it could transcend territorial borders with the essential content of the economic."3

That particular belief found its roots in the legal context of sea warfare. The boundless and total nature of sea warfare, while conceptually evolving into ideological claims in the name of "humanity" and "progress," resulted in the reintroduction of new forms of just war doctrines. Beginning with Woodrow Wilson in World War One, wars were no longer considered duels in the traditional $18^{\text {th }}$ century sense of cabinet wars. Rather it was stipulated with the establishment of the League of Nations, that states would now need a just cause to initiate hostilities. Of course the natural question always

\footnotetext{
${ }^{1}$ The special case of the Monroe doctrine illustrates the "exceptional" nature of the United State's claim to allow for a hemispheric zone of non-intervention that had no precedent in public European international law.

${ }^{2}$ Schmitt, The Nomos of the Earth in the International Law of the Jus Publicum Europaeum. pp. 255-256

${ }^{3}$ Ibid. p. 258
} 
remained: with whom lies the ability to decide on the validity of such claims? And yet the persistent attempts at seeking to attenuate the political divisions through universal economic relations alongside with institutional legislative or juridical approaches only served to reinvigorate the political divisions between states. Those powers that wanted to maintain the status quo utilized newly developed juridical doctrines to delegitimize and, by consequence, criminalize the reevaluation of territorial changes by calling such attempts aggression. In this case, the discriminatory conception of war, by reducing the traditional concept of sovereign equality and reciprocity, simply resulted in the radicalization of the concept of enmity. Branded the disturber of the peace, the enemy came to be considered an outlaw alongside that of the pirate, for example. Wars, then, became a matter for the human race as a whole to wage, which, by consequence, transformed the concept of war into global civil wars exercised in the name of international "police" actions.

Schmitt clearly recognized the irony inherent in the liberal goal of attempting to replace the political with the economic. This move simply resulted in the transfiguration of the friend/enemy division into a more intense division; the previous set of norms that bracketed conflicts were no longer considered legitimate while maintaining an orderly balance between European states. The post-World War One international order based on liberal universal principles did not emerge as one that was able to maintain the unity between order and orientation. Instead, Schmitt saw that the then current attempts at establishing an order, beginning with the Versailles treaty, ushered in a profound crisis of legitimacy. While the European public order of states recognized a supra-legitimacy in the recognition of each state's sovereign right to make war, it resulted in a robust 
approach for solving territorial disputes without endangering the order itself. The nature of alliances, the balance of power, and territorial delimitations within European might have changed, but the concrete order did not. Nor did the interests of certain powers to the detriment of others that sought to establish a status quo strictly based on peace. After the Congress of Vienna, for example, the legitimacy of the European order was reestablished on the basis of the dynastic monarchy. Each was considered an equal player in the continuous game of European rivalries and duels. In no way was there any attempt at calling into question the legitimacy of the political rival. What transpired after the First World War was instead the desire to completely reify the international system. Peace was then considered the foremost criterion of legitimacy while those that sought to usurp that criterion were branded outside the law. The very legitimacy of the state was called into question on a principle of moral righteousness and indignation in the face of a catastrophic war of attrition. But the attempt to reify the status quo post-World War One was rendered deeply problematic at a time when other powers simply could not accept this form of legitimacy imposed by the victors of the First World War. Germany's inability to swallow the diktat of Versailles is a clear example of that. More generally, the relative power between states necessarily changed over time. This problem can translate into radically changing the foreign policies of states to more aggressive postures. Characteristically, the goal of institutional liberals is to assure that political changes can be conducted within a legal framework that does not have recourse to war. Schmitt recognized the general problematic of trying to reify territorial conditions in the name of stability when he wrote: 
In an age of rapid changes and technological progress, it is remarkable that the status quo should be guaranteed...In fact, the desire to find stability, peace, and justice is linked with the inability to find a legal principle, a principle of legitimacy. One cannot guarantee a factual situation, but only a legal situation, and this legal situation is possible only if it is considered to be normal. If this is so, and one cannot rationally dispute it, then the internal contradiction in the moral situation of Europe appears to be frightful. The existing situation is so unsatisfactory, so abnormal and, consequently so unstable, that the longing for stability becomes stronger day by day. The demand for a guarantee of the status quo stems from this longing for peace and stability, i.e., a stabilization. But a stabilization of existing conditions would stabilize precisely this unsatisfactory situation lacking stability, and the result of such a perpetuation and legalization will not be stability and peace, but the creation of new conflicts, sharper contradictions, and the perpetuation of the absence of stability. ${ }^{4}$

To be sure, the very proposition of attempting to guarantee the status quo as peace, devised as the principle measure of legitimacy, presents itself as a chimerical negation of the concept of the political. It represents the first stage in an attempt at globalization within the framework of a universalism of humanity. Here, Heinrich Meier associates Schmitt's hostility to globalization with a deeply theological premise situated in the Katechon as the restrainer against the "lawless" Anti-Christ. ${ }^{5}$ The hubristic manmade unification of the world represents a false eschatological vision where genuine political action - as historical action - is rendered meaningless. The unification of the globe represents the moment in time when the distinction between Christ and anti-Christ evaporates. Only at the moment of the second coming of Christ, where God vanquishes the anti-Christ, can a genuine universal order come into existence. The Katechon, which appears throughout history in the form of a concrete political order and which supposedly prolongs the Last Judgment, must exist, Meier continues, in order for Schmitt to

\footnotetext{
${ }^{4}$ Quoted in the introduction written by G.L Ulmen Ibid. p. 14

${ }^{5}$ Meier, The Lesson of Carl Schmitt: Four Chapters on the Distinction between Political Theology and Political Philosophy. pp. 160-162
} 
"preserve his faith in the truth of revelation and to remain in harmony with himself.", This reading necessarily assumes that Schmitt's political thought is fundamentally driven by a theological inspiration. However, as was shown in the preceding chapters, that reading remains problematic. In addition, Schmitt's emphasis on the foundational nature of land-appropriation as constituting a nomos displays an essential transcendence, not as a theological endeavor, but ultimately as a genuine political action that renders life meaningful. Nonetheless, it is precisely at the moment of absolute enmity, of absolute and total conflict, engendered by the attempt to abolish the political that the theological basis finds its grounding:

The annihilation of the enemy is but an attempt (the claim) of a creatio ex nihilo. Of a new world from a tabula rasa. Anyone who wants to annihilate me is not my enemy, but my Satanic tormentor. The question of how I should behave towards him can no longer be politically but only theologically answered. Dialectical theology of the most concrete kind arises when the annihilator claims to want to annihilate only the annihilator. ${ }^{7}$

Today, the desire to eradicate "tyranny," "terrorism," "outlaw regimes" or whatever is defined as the current amorphous enemy is then no longer the domain of political as such, but rather the basis for an unmitigated and unrestrained violence. The divine like violence that results from the construction of the absolute enemy is characterized by the lack of a contemporary concrete order. Schmitt would not have been surprised to see the turn towards a political theology of absolutism emanating from the United States. That he saw as being prefigured in the nihilistic basis of its transcendental legitimacy not rooted in a concrete nomos.

\footnotetext{
${ }^{6}$ Ibid. p. 162

${ }^{7}$ Quoted in Balakrishnan, The Enemy: An Intellectual Portrait of Carl Schmitt. p. 255
} 
II Against the Making of International Orders: Then and Now?

We should not be surprised that the language used in the current war against terror is theologically inspired. The numerous references that define the enemy as an "axis of evil" should not be viewed simply as a rhetorical strategy originating within the present administration, but rather as the continuing evolution towards an absolutism of enmity. ${ }^{8}$ One can see this as well in the telling off the cuff remark by Bush that "this crusade, this war on terrorism, is going to take awhile."9

One of the consequences of such global visions, past or present, is that the political division of friend and enemy is transformed from a relation between equally recognized sovereign states into an extreme struggle against those that are deemed to constitute exceptions to the rule. But what is clear is that this attempt at global transformation results in an ever-conflated boundary between norm and exception. Schmitt saw this tendency as the decoupling of international law from its state-centered mooring: on the one hand, the global liberal democratic aspirations of "one world" that de-centers the sovereign state; on the other hand, the Leninist appeal to global revolution for the emancipation of the proletariat. Both of these ideologies construct an absolute enemy that can have no place in international law. In the case of Lenin, Schmitt writes:

Lenin established the main conceptual shift from war to politics, i.e., to the distinction of friend and enemy. It was reasonable and a consequential extension of Clausewitz's idea of war as a continuation of politics. But Lenin, the professional revolutionary of world-

\footnotetext{
${ }^{8}$ George W. Bush, The President's State of the Union Address (2002 [cited 10/2 2005]); available from http://www.whitehouse.gov/news/releases/2002/01/20020129-11.html.

${ }^{9}$ Sally Buzbee, Bush's Use of Word 'Crusade' a Red Flag (Associated Press, September 18, 2001 [cited 10/3 2005]); available from http://seattlepi.nwsource.com/national/39266_crusade18.shtml.
} 
wide civil war [Weltbürgerkrieges], went even further and made an absolute enemy out of a real enemy. ${ }^{10}$

Lenin, it should be recalled, advocated the necessity of overthrowing, by violent means, the liberal-bourgeois order throughout the world: "Only after we have overthrown, finally vanquished and expropriated the bourgeoisie of the whole world, and not merely of one country, will all wars come to an end." ${ }^{11}$ Moreover, Lenin rearticulated a conception of just war based on the proletariat's natural right to commence wars of liberation. The dichotomy is not of a liberal distinction between offensive or defensive war here, but rather entirely based on the class conflict whereby the proletariat always has a just cause to commit violence. ${ }^{12}$

We should perhaps not be surprised if today, even after the collapse of the Soviet Union in the early 1990s and the triumphalism of liberal-democratic ideology, there is a similar form of reasoning similar to the one that propelled the Leninist conception of worldwide revolutionary struggle, but now taking hold in the United States. The interregnum of the 1990s, a period of time in which the United States lacked a clearly defined geopolitical strategy, forced many strategists to reappraise the position of the United States from a maintainer of the status quo to a more proactive enforcer of universal global transformations. Michael Ledeen, a leading American neo-conservative, argued before $9 / 11$ :

\footnotetext{
${ }^{10}$ Carl Schmitt, "Theory of the Partisan: A Commentary/Remark on the Concept of the Political," New Centennial Review 4, no. 3 (2004 (1963)). p. 66

${ }^{11}$ Quoted in Bolsinger, The Autonomy of the Political: Carl Schmitt's and Lenin's Political Realism. p. 144

${ }^{12}$ Ibid. p. 145-148
} 
It is America's inescapable mission to fight for the spread of democracy, and therefore against tyranny. This is so because of who we are: the most successful democratic society in history...we are the most revolutionary force on earth. We are not going to fight foreign wars or send our money overseas merely to defend the status quo; we must have a suitably glorious objective... The only truly realistic American foreign policy is an ideological one that seeks to advance the democratic revolution wherever and whenever possible. $^{13}$

This growing emphasis on transforming the globe into a universe of liberal-democratic peoples gained new credence in a post September 11 world. Where security is judged as being tied not to geopolitical criteria but to the total eradication of "tyranny," "rogue" states, or terrorism, then any means is considered legitimate in such a pursuit. The active promotion of revolutions in the former Soviet republics, for example, becomes perceived as a necessary "good" in contravention of the norm of non-intervention. Indeed, the United States Department of State recently developed a program entitled the Active Response Corps, whose mission will be "to help young democracies succeed and build these institutions of liberty." As a result, the program stipulated that "we, [the United States] must enlist the help of many individuals and institutions: non-governmental organizations have a role to play; the United States government has a role to play; and the world's free nations all have important roles to play."14 The logic of the second Gulf war is thus reformulated to fit into these criteria of promoting democratic "revolutionary" change throughout the Middle East. It is claimed that, only with the advancement of liberal-democratic ideals, the Middle East can transform itself from a haven and

\footnotetext{
${ }^{13}$ Michael Ledeen, American Power--for What? (Commentary, 2000 [cited 10/2 2005]); available from http://www.aei.org/publications/pubID.11141, filter.all/pub_detail.asp. My emphasis

14 George W. Bush, Supporting Emerging Democracies (2005 [cited 10/2 2005]); available from http://www.state.gov/s/crs/rls/rm/46818.htm.
} 
production site for terrorism to "the long-delayed reform and modernization of Islam.","15 From this new liberal vision of order, Iraq becomes the staging ground of a supposedly democratic and capitalistic revolution throughout the Middle East. It is one in which the legitimacy of military intervention is consciously justified, not by concrete necessity, but rather by way of a revolutionary form of violence that no longer recognizes any boundaries except its own moral self-righteousness. ${ }^{16}$ Schmitt wrote prophetically:

Today, in 1943, the USA seeks to establish itself in Africa and the Near East; on the other side of the globe, it reaches up into China and Middle Asia. It spans the entire earth with a system of airforce bases and runways, and proclaims and American Century for our planet. With that, all conceivable boundaries, however broadly conceived, are eliminated. ${ }^{17}$

What is implicitly driving the current American approach to world politics is, at its core, an alchemist claim of transforming the political into the economic and the ethical. This acceptance of the "end of history" thesis, as mentioned in the introduction, represents a belief in the rationale behind the idea of the struggle for recognition, in which the individual finds his raison d'etre only in a liberal-democratic and capitalistic world system. Thus, "the old tenet that one is not to expect full security in this life plena securitas in hac non expectanda - would be obsolete."18 But, in this world-view, man can no longer be considered as dangerous; it is the ultimate liberal faith that educable man takes center stage. However, this view does not come to grips with the

${ }^{15}$ Norman Podhoretz quoted in A. J. Bacevich, The New American Militarism : How Americans Are Seduced by War (New York: Oxford University Press, 2005). p. 95

${ }^{16}$ See Tzvetan Todorov, The New World Disorder: Reflections of a European (Malden: Polity, 2005). pp. 23-35; Bacevich, The New American Militarism : How Americans Are Seduced by War. pp. 92-96

${ }^{17}$ Quoted in Balakrishnan, The Enemy: An Intellectual Portrait of Carl Schmitt. p. 239

${ }^{18}$ Schmitt quoted in Meier, The Lesson of Carl Schmitt: Four Chapters on the Distinction between Political Theology and Political Philosophy. p. 165 emphasis in the original 
inherent lacunae of an international law that is nonetheless supposed to govern the relationship between war and peace. This vision either presupposes that conflict will simply disappear and a form of perpetual peace will emerge, or that it will result in the materialization of a global leviathan.

While there is today this faith in constructing an improved and unified world at some point in the future, there also remains an ever-present inability to concretely demarcate the "line" that separates the norm and the exception, the inside and outside. The merging of the normal and the exceptional creates a 'juridically empty' space and makes such concepts such as war, peace, and neutrality highly problematic. This is a consequence of the structural inability to define the proper boundaries of what constitutes a normal situation in the contemporary international order. In fact, in this view of order and of the earth, there could no longer be any territorially conceived inside or outside, and no longer could there be any constitutive process for the "'taking of the outside,' and exception", as Agamben refers to it. ${ }^{19}$ Schmitt's prophetic consciousness of this was evident in the fact that he fancifully spoke of the possibilities of opening a new space beyond the earth:

Our problem thus expands to planetary dimensions. It grows even further into outer space. Technical progress also makes possible, opening simultaneously immense new challenges for political conquest. For these new spaces could be and must be taken by men. Space appropriation of a new kind would follow the old-fashioned land and sea occupations familiar to human history. Division and grazing would follow the appropriation. All progress notwithstanding, in this respect things remain as they were. ${ }^{20}$

\footnotetext{
${ }^{19}$ Agamben, Homo Sacer: Sovereign Power and Bare Life. p. 19

${ }^{20}$ Schmitt, "Theory of the Partisan: A Commentary/Remark on the Concept of the Political." p. 57
} 
The earth itself, then, no longer contains any free space for the appearance of genuine and free action that has characterized preceding epochs. Instead, as was shown in the last chapter, the internalization of the state of exception and its localization in the concentration camp, that place where man is reduced to bare life, becomes the guiding feature of the modern biopolitical order.

In a sense then the current global order is one of, following both Emile Durkheim and Agamben, anomie, to be without nomos, an order where violence is ultimately decoupled from its, that is to say, literally, juridical setting. ${ }^{21}$ Durkheim defined anomie as that social state representing a space in which the moral norms and rules that limit the desires of an individual are suspended or degraded.

The state of anomie is impossible whenever interdependent organs are sufficiently in contact and sufficiently extensive. If they are close to each other, they are readily aware, in every situation, of the need which they have of one-another, and consequently they have an active and permanent feeling of mutual dependence. ${ }^{22}$

This recognition of the possibility of anomie within any nomos was perhaps why Schmitt, as noted in the first chapter, had such a problem with the project of modernity in general. The modern world's emphasis on an ungrounded abstract conception of international law cannot appropriately set limits within itself. Thus, it necessarily results in the freeing of violence for any purpose or, rather, for any utopian endeavor that comes into fashion.

In his work on the state of exception, Agamben does note the tension between anomie and nomos that has characterized western political thought. As Agamben convincingly argues, it was Schmitt's aim in Political Theology to reply to Walter

\footnotetext{
${ }^{21}$ Agamben, State of Exception. See chapter IV

22 Emile Durkheim, Selected Writings, ed. Anthony Giddens, trans. Anthony Giddens (Cambridge: Cambridge University Press, 1972).p. 184
} 
Benjamin's Critique of Violence as a way of reintroducing the state of exception within a juridical context. Benjamin's stipulation of a pure form of violence removed from law was located within the space of anomie and thus remained without any form of boundary condition. It was an all-encompassing "divine violence" that was not law-preserving or law-making in nature. As Agamben continues:

The stakes in the debate between Benjamin and Schmitt on the state of exception can now be defined more clearly. The dispute takes place in a zone of anomie that, on the one hand, must be maintained in relation to law at all costs and, on the other, must be just as implacably released and freed from this relation. That is to say, at issue in the anomic zone is the relation between violence and law - in the last analysis, the status of violence as a cipher for human action. While Schmitt attempts every time to reinscribe violence within a juridical context, Benjamin responds to this gesture be seeking every time to assure it - as pure violence - an existence outside of the law. ${ }^{23}$

What Schmitt, according to Agamben, recognized in the international juridical setting after the First World War was precisely this anomic constitution whereby violence can become totalized. Violence, decoupled from a juridical context leads to the very catastrophes witnessed throughout the $20^{\text {th }}$ century and possibly continuing in the $21 \mathrm{st}$ century. Furthermore, Schmitt clearly recognized that one of the consequences of such a decoupling was the emergence of new forms of irregular violence. Alongside the call for revolutionary violence originally heard in Lenin's discourse was a growing emphasis on the individual's ability to take up arms outside the context of the regular armed forces. The rise of the irregular partisan, guerilla, insurgent, or modern day terrorist was the clearest manifestation of violence within this international state of anomie. ${ }^{24}$ The current conflict between terrorism and counter-terrorism, within the context of a global civil war,

\footnotetext{
${ }^{23}$ Agamben, State of Exception. p. 59

${ }^{24}$ Schmitt, "Theory of the Partisan: A Commentary/Remark on the Concept of the Political."
} 
is the rootless and boundless conflict par excellence which in fact has its roots in the destruction of the old nomos of the Jus Publicum Europaeum.

III Excursus: The Kantian Retrieval, Habermas and Rawls on the International Legal Order

Twentieth century normative theorists Jürgen Habermas and John Rawls both sought to retrieve and build upon a Kantian conception of cosmopolitan right that could recreate a form of order between states in a post-Cold War world. Habermas's essay, "Kant's Idea of Perpetual Peace: At Two Hundred Years' Historical Remove," aims at "something more than the weak regulation of belligerent international relations by international law." 25 Anticipating Schmitt's objection to utilizing a universal moralistic basis for structuring the principles of cosmopolitan law as a human rights regime in the international system, Habermas focuses on severing law from a moral basis. He first points out, though, that Kant's project necessarily relies not upon a notion of legal obligation to induce states to subordinate their political interests, but rather on a "moral self-obligation." ${ }^{, 26}$ However, this "moral" conception of obligation cannot form the basis of a sustained cosmopolitan law given that it does not address the potential reassertion of reasons of state between fully sovereign states that coexist within the Kantian universe. Thus Habermas departs from this starting point to argue for a form of cosmopolitan law not entirely based on a moral inducement to obligation, but rather on a conception of

\footnotetext{
${ }^{25}$ Jürgen Habermas, "Kant's Idea of Perpetual Peace: At Two Hundred Years Historical Remove," in The Inclusion of the Other: Studies in Political Theory, ed. Ciaran Cronin and Pablo De Greiff (Cambridge: MIT Press, 1998). p. 165

${ }^{26}$ Ibid. p. 169
} 
legality. What does Habermas mean by cosmopolitan international law? For one, it

"would resemble state-sanctioned civil law in definitively bringing the state of nature to an end." ${ }^{27}$ Habermas departs from Kant's voluntary association of republican states in Perpetual Peace by arguing that "Cosmopolitan law must be institutionalized in such a way that it is binding on individual governments. ${ }^{28}$ Moreover, much like what George Scelle first argued in Précis de Droit des Gens, Habermas sees the necessity of transforming the traditional notion of sovereignty to encompass an individual's equal and rightful claim to world citizenship. As he writes, "The point of cosmopolitan law is, rather, that is bypasses the collective subjects of international of international law and directly establishes the legal subjects by granting them unmediated membership in the association of free and equal world citizenship." ${ }^{, 2}$ We can see the rudiments of this today, for example, in the universal jurisdiction of Geneva Convention violations in which those individuals acting in the name of a state are not absolved from being potentially prosecuted in other countries. ${ }^{30}$ However, Habermas also recognizes the "discrepancy

\footnotetext{
${ }^{27}$ Ibid. p. 168

${ }^{28}$ Ibid. p. 179

${ }^{29}$ Ibid. p. 181; Habermas also writes: "Things look quite different, when human rights are not just regarded as a moral guide for one's own political actions but as rights which have to be implemented in a legal sense. Disregarding their moral content, human rights essentially display the structural features of subjective rights, which naturally have to be framed by some form of obligatory law in order to gain any positive value. Only if human rights enter the legal sphere of a worldwide democratic legal order, similar to the basic human rights embedded in our national constitutions, will we be able to say that the addressees of these rights can see themselves also as their authors." Jürgen Habermas, Bestiality and Humanity: A War on the Border between Law and Morality (2000 (1999) [cited 09/21/2005); available from $\mathrm{http}: / / \mathrm{www}$. theglobalsite.ac.uk/press/011 habermas.htm.

${ }^{30}$ A very recent case is that of Israeli general Doron Almog, head of southern command in Gaza, for violations. A British magistrate issued an arrest warrant citing that he would need to face charges for violations of the $4^{\text {th }}$ Geneva Conventions in a British court. Israel General 'Avoids Uk Arrest' (2005 [cited 09/17 2005]); available from http://news.bbc.co.uk/2/hi/uk_news/4237620.stm.
} 
between the letter and the observance of these norms."31 To bridge this gap, he proposes a seemingly non-violent process of reconfiguring societies through external actions:

The implementation of regulations should neither harm the existence and self-respect of the members, nor so impair vital interests and justice concerns that the parties to a conflict end up resorting to violence when the procedural possibilities have been exhausted. Policies that take their orientation from such a concept of peace will employ all means short of military force, including humanitarian intervention, to influence the internal affairs of formally sovereign states with the goal of promoting self-sustaining economies and tolerable social conditions, democratic participation, the rule of law, and cultural tolerance. ${ }^{32}$

Though he focuses upon non-violent interference in the internal affairs of sovereign states for the sake of improving economic, social, and political conditions, Habermas' mention of humanitarian intervention is indicative of a residual necessity for the use of military power in order to enforce cosmopolitan law. In fact, Habermas does argue for the necessity of a more centralized executive to guarantee the enforcement of universal human rights to the detriment of sovereign power. This can more precisely be gauged in his cited example of Security Council resolution 688 which created the no-fly zones in Iraq after the first Gulf War. The legal premise was that Iraq was determined to pose a "threat to international security," in which case, the creation of these no-fly zones was not to be construed as internal interference. ${ }^{33}$

Nonetheless, fundamental ambiguities remain in Habermas's attempt at devising a cosmopolitan and equitable world order. For one, it does not fully answer the Schmittian question of who decides when the use of military force is permissible. Likewise, an ambiguity remains as to what properly constitutes a threat to international security. By

\footnotetext{
${ }^{31}$ Habermas, "Kant's Idea of Perpetual Peace: At Two Hundred Years Historical Remove." p. 183

${ }^{32}$ Ibid. p. 185 my emphasis

${ }^{33}$ Ibid. p. 182
} 
trying to elevate the United Nations Security Council to the rank of that institution with the power to make decisions on the maintenance of war and peace, Habermas' proposal remains highly questionable since the members of this council will have to divorce their own political interests from the pursuit of justice and social progress in the world. This is also not to mention the fact that the United Nations Security Council is by no means a democratic organization that can effectively acquire the category of legitimacy desired by Habermas. Moreover, nothing can stop a great power from circumventing the council in a decision on war and peace. The example of the second Gulf War was once again indicative of this. As dubious as it was that Iraq posed such a threat to international security that necessitated immediate intervention, the United States then felt the need to cloud its arguments for war in precisely the humanitarian language of progress and social development that neatly fits into Habermas's own language. The language of international security and international law thus becomes conflated to provide justifications for the pursuit of political interests. Habermas's claim remains that the emphasis on a cosmopolitan law between states provides a measure of legitimacy for multilateral interventions, as was the case in Kosovo in 1999, for example. ${ }^{34}$ Nevertheless, it still remains an open question whether unipolarity can effectively guarantee a cosmopolitan order without utilizing the concepts of humanitarian right for the purpose of explicit self-interest. Habermas himself places faith in the United States as

${ }^{34}$ See Habermas, Bestiality and Humanity: $A$ War on the Border between Law and Morality ([cited). NATO powers intervened against the Serbian militia and military presence in its province of Kosovo where is was engaged in a systematic ethnic cleansing of ethnic Albanians. The United States, France, and Britain were unable to pass a specific Security Council resolution authorizing the use of force because of a Russian threat to veto. The case for intervention based on the immediacy of a humanitarian catastrophe. That, it was argued, allowed for the legitimate intervention in the internal affairs of Serbia. See Jane Stromseth, "Rethinking Humanitarian Intervention: The Case for Incremental Change," in Humanitarian Intervention: Ethical, Legal, and Political Dilemas, ed. J.L. Holzgrefe and Robert O. Keohane (Cambridge: Cambridge University Press, 2003). pp. 234-238 
the ultimate guarantor of this order, although Kant would probably have seen it as problematic for any one power would be placed in such a position. ${ }^{35}$

Habermas's emphasis on the "police" or "peace-making" nature of contemporary warfare undermines the traditional condition of legal equality between sovereigns. Concurrently, this renders the end of the war between parties highly problematic too: either there is an unconditional demand of surrender from one party, or there is a criterion for the sanction and punishment, as in Versailles, of the opposing party, something that did not exist in the Jus Publicum Europaeum. By interposing a condition of legality, one party is conducting a legal war while the other is conducting an illegal one. Does this not lead to the criminalization of the political opponent as Schmitt argued? Habermas seeks to escape Schmitt's critique by arguing that:

For the establishment of a cosmopolitan order means that violations of human rights are no longer judged and combated immediately from the moral point of view, but rather are prosecuted, like criminal actions, within the framework of state-organized legal order, in accordance with institutionalized legal procedures. Precisely the juridification of the state of nature among states prevents a moral de-differentiation of law and guarantees the accused full legal protection, and hence protection against unmediated moral discrimination, even in the currently relevant cases of war crimes and crimes against humanity. ${ }^{36}$

However, as Hans Joas points out, Schmitt's concern was precisely the inherent possibility for the extreme intensification of conflict during the actual process of bringing about a justifiable end. ${ }^{37}$ Habermas does not explain how sovereign states would autolimit themselves during the prosecution of human rights violations. More importantly

\footnotetext{
${ }^{35}$ Gopal Balakrishnan, "Overcoming Emancipation," New Left Review 19 (2003). p. 126

${ }^{36}$ Habermas, "Kant's Idea of Perpetual Peace: At Two Hundred Years Historical Remove." p. 193; Also quoted in Joas, War and Modernity. emphasis in the original

${ }^{37}$ Joas, War and Modernity. p. 22
} 
however, what we see in Habermas is the reintroduction of the interwar attempts at fashioning a pacific union of states that subsume their respective political interests. This is, in other words, a quasi-federation that removes the right of war between member states, while subjecting it to criminal law, and instead refashions it towards those cases that are considered humanitarian exceptions.

Section V of Habermas' essay presents a critique of Schmitt's position. He argues that behind the call for a non-discriminatory conception of war lies a hidden motive that explains Schmitt's views. For one, Habermas argues "that Schmitt not only wanted to see offensive war decriminalized but also the barbarous extermination of the Jews." ${ }^{38}$ By that, Habermas continues, Schmitt wanted to devalue the concept of a "crime against humanity' as an empty juridical concept because "such a crime cannot be circumscribed with sufficient precision." ${ }^{39}$ However, this interpretation absolutely neglects Schmitt's own writings on the Geneva conventions as a set of rules that govern the conduct of war and the behavior of states during periods of occupation. Schmitt wrote that

The four Geneva Conventions of 12 August 1949 are the work of a humane conscious, and a humanitarian development that deserves our admiration. While they not only permit the enemy a share of humanity but even of legitimacy in the sense of recognition [Gerechtigkeit im Sinne der Anerkennung], they remain grounded in classical international law and its tradition without which such a work of humanity would have been unlikely. ${ }^{40}$

Be that as it may, Habermas does acknowledge, "the kernel of truth is that an unmediated moralization of law and politics does in fact break through those protective zones that we

\footnotetext{
${ }^{38}$ Habermas, "Kant's Idea of Perpetual Peace: At Two Hundred Years Historical Remove." p. 195

39 Ibid.

${ }^{40}$ Schmitt, "Theory of the Partisan: A Commentary/Remark on the Concept of the Political." p. 22
} 
want to have secured for legal persons of good, indeed moral, reasons." ${ }^{, 41}$ But he is mistaken in that a clear-cut line can be drawn between a legal framework based on a notion of abstract normative human rights and the excess moralization of the political as a result of implementing those norms. The current problematic of finding ad hoc justifications for intervention, as in the case of Iraq in 2003, points to this inherent lacuna in positive international law. Moreover, there does not appear to be any consensus on who could monopolize the decision as to what properly constitutes a set of legitimate criteria for the use of armed conflict.

Another approach that attempts to ground a liberal international legal order is the one provided by John Rawls in one of his last publications The Law of Peoples. ${ }^{42}$ Rawls sets out to formulate a "realistic utopia," building upon his previous work in $A$ Theory of Justice and Political Liberalism, as one that "extends what are ordinarily thought to be limits or practical political possibility and, in so doing, reconciles us to our political and social condition." ${ }^{43}$ Rawls seeks to systematically construct a foundation for the establishment of international justice that departs from a conception of political liberalism at the domestic level. Initially, he seeks to escape the traditional political distinction of sovereignty by focusing on the concept of peoples rather than states. By utilizing the concept of peoples, the goal is to "highlight their moral character and the reasonably just, or decent, nature of their regimes." 44 The traditional concern with

\footnotetext{
${ }^{41}$ Habermas, "Kant's Idea of Perpetual Peace: At Two Hundred Years Historical Remove." p. 199

42 John Rawls, The Law of Peoples: With "the Idea of Public Reason Revisited" (Cambridge: Harvard University Press, 1999).

${ }^{43}$ Ibid. p. 11
} 
identifying the rationality of the particular actions of a state, as seen in the realist conception of raison d'etat as national interest, is rejected here and replaced with a concept of reasonableness derived from the liberal theory of reciprocity. ${ }^{45}$ Furthermore, in speaking of the possibility of a law of peoples, a difference principle is established between liberal peoples that embody constitutional structures and conceive of justice as fairness or, what Rawls calls "reasonable liberal peoples," and those that do not meet this criterion. ${ }^{46}$ Ultimately, Rawls arrives at a set of principles that constitutes his law of peoples:

1. Peoples are free and independent, and their freedom and independence are to be respected by other peoples.

2. Peoples are to observe treaties and undertakings.

3. Peoples are equal and are parties to the agreements that bind them.

4. Peoples are to observe a duty of non-intervention.

5. Peoples have the right of self-defense but no right to instigate war for reasons other than self-defense.

6. Peoples are to honor human rights.

7. Peoples are to observe certain specified restrictions in the conduct of war

8. Peoples have a duty to assist other peoples living under unfavorable conditions that prevent their having a just or decent political and social regime. ${ }^{47}$

My goal here is not to argue about the basis of Rawls' construction of such a law of peoples. ${ }^{48}$ Rather, my focus is on demonstrating the problematic consequences of such a

\footnotetext{
${ }^{44}$ Ibid. p. 27 My emphasis

${ }^{45}$ Ibid. p. 28

${ }^{46}$ lbid. p. 4; Rawls specifies a set of different "orderings" that establish their placement within the law of peoples: "decent people", a people that does embody a form of consultation hierarchy, which Rawls groups with "reasonable liberal peoples" as "well-ordered peoples"; outlaw states, "societies burdened by unfavorable conditions" and "benevolent absolutism."

${ }^{47}$ Ibid. My emphasis

48 For a critical discussion see for example Regina Kreide, "Book Review: The Law of Peoples," Constellations 9, no. 4 (2002). Also see Andrew Kuper, "Rawlsian Global Justice: Beyond the Law of Peoples to a Cosmopolitan Law of Persons," Political Theory 28, no. 5 (2000).
} 
so-called international theory of justice that reformulates the question of war and peace into self-styled "police" interventions that find their legitimacy along a moral norm.

In section two and three of his book, Rawls expands on this notion to argue for the explicit right of intervention in the affairs of states deemed "outlaws" or "societies burdened by unfavorable conditions." Human rights are an integral part of the law of peoples and hence are universally binding on all peoples including "outlaw" states. ${ }^{49}$ But who is to decide what constitutes a just war or not? Though Rawls seeks to draw a connection between the Christian natural law doctrine of just war, he leaves the ultimate authority of decision to an unspecified political structure called "decent peoples." These "outlaw states" (here Rawls reverts back to the concept of the state to show the explicit division between the action of state versus its people who is usually perceived as being innocent) become, accordingly, intolerable entities in need of redress: "Their [wellordered peoples] long run aim is to bring all societies eventually to honor the Law of Peoples and to become full members in good standing." not meet Rawls' conception of justice can, in certain situations, be directly targeted for military intervention. ${ }^{51}$ In this case, Rawls integrates a Schmittian appeal to an emergency situation, to a "supreme emergency exemption" that allows "well-ordered" peoples to set aside the rules of war. As he asks, "Were there times during World War II when Britain could properly have held that civilians strict status was suspended, and thus

\footnotetext{
${ }^{49}$ Rawls, The Law of Peoples: With "the Idea of Public Reason Revisited". p. 80

${ }^{50}$ Ibid. p. 93

${ }^{51}$ See also Perry Anderson, "Arms and Rights: Rawls, Habermas and Bobbio in an Age of War," New Left Review 31, no. January-February (2005).
} 
could have bombed Hamburg and Berlin?"52 Ironically for Rawls, The answer is ultimately contingent upon a consequentialist interpretation of the effectiveness of the suspension. Thus, the firebombing of Dresden and the atomic attacks on Hiroshima and Nagasaki, though considered great wrongs and failures of leadership, nonetheless become legitimate if they are judged, by the Allies it should said, as effective means of prosecuting the war to its end. ${ }^{53}$

Whereas Habermas's cosmopolitan approach is ultimately concerned with the welfare of the individual and the legalization of the international system, Rawls focuses on moralizing the international order by means of a law of peoples that can ultimately legitimate total wars against outlaw states. This approach is a clear reformulation of a utopian vision of global order that reintegrates a conception of just war for the sake of an end state of well-ordered peoples living in perpetual peace.$^{54}$ In the end, the very idea of devaluing the political traditional structures of power and authority for the sake of establishing a law of peoples is itself part of the problem. To speak of "peoples" conjures up the various hopes and visions of the $20^{\text {th }}$ century, of smoothing out the fractious nature of the globe. Agamben summarizes this tendency when he writes:

...our age is nothing but the implacable and methodical attempt to overcome the division dividing people, to eliminate radically the people that is excluded. This attempt brings together, according to different modalities and horizons, Right and Left, capitalist countries and socialist countries, which are united in the project - which is in the last analysis futile but which has been partially realized in all industrialized countries - of producing a single and undivided people. The obsession with development is as effective as it is in our time because it coincides with the biopolitical project to producer an undivided people... Only a politics that will have learned to take the fundamental

\footnotetext{
${ }^{52}$ Rawls, The Law of Peoples: With "the Idea of Public Reason Revisited". p. 98

${ }^{53}$ Ibid. pp. 98-101

${ }^{54}$ In fact, Rawls subscribes to the conjecture of democratic peace theory. Ibid. pp. 51-55
} 
biopolitical fracture of the West into account will be able to stop this oscillation and to put an end to the civil war that divides the peoples and the cities of the earth. ${ }^{55}$

IV Finding a Nomos of the Earth: Schmitt's Concept of Grossraum

In his famously dark novel 1984 , George Orwell describes how, during the $20^{\text {th }}$ century, nation-states coalesce into three major geographic blocs: Oceania, Eurasia, and Eastasia. These blocs, composed of similar isolated totalitarian universes, are engaged in a perpetual war against each other. Alliances between different blocs may shift, as the protagonist Winston tries to remember that it was not four years ago that Oceania was at war with Eastasia instead of Eurasia, but this remains hidden from the public at large. And yet what remains apparent in 1984 is that, though war is never-ending, it is not existential in scope. As Orwell writes through the character of Emmanuel Goldstein:

In one combination or another, these three super-states are permanently at war, and have been so for the past twenty-five years. War, however, is no longer the desperate, annihilating struggle that it was in the early decades of the twentieth century. It is a warfare of limited aims between combatants who are unable to destroy one another, have no material cause for fighting and are not divided by any genuine ideological difference... But in a physical sense war involves very small numbers of people, mostly highly-trained specialists, and causes comparatively few casualties...To understand the nature of the present war -- for in spite of the regrouping which occurs every few years, it is always the same war -- one must realize in the first place that it is impossible for it to be decisive. None of the three super-states could be definitively conquered even by the other two in combination. They are too evenly matched, and their natural defences [sic] are too formidable...Moreover, no fighting ever occurs except in the disputed areas round the Equator and the Pole: no invasion of enemy territory is ever undertaken.

For Emmanuel Goldstein war, then, is simply a matter of "imposture," a virtual reality, or, a perpetual occurrence that is totally geared toward the internal subjugation of the local inhabitants without concrete external consequences. Whereas previous wars could

\footnotetext{
${ }^{55}$ Agamben, Homo Sacer: Sovereign Power and Bare Life. pp. 179-180
} 
be understood through an inherent political rationale based, pace Clausewitz, on a continuation of politics, in Orwell's world "the object of the war is not to make or prevent conquests of territory, but to keep the structure of society intact." ${ }^{\text {56 }}$ Moreover, these self-contained autarkic large spaces or orders, which displace the individual from any concern for the war effort (except for that of hatred towards the current enemy), result in an absolute indistinction between war and peace. Hence, the party slogan that "WAR IS PEACE."

While Orwell's conception of global order is one characterized by a deeply pathological utopianism that necessitates not only the control of speech in all aspects but also of thought, it still illustrates a possible geopolitical configuration that redefines the normative content of the international system as a concrete order. The bracketing of war is established by displacing it to peripheral spaces; a balance is retrieved that does not allow for the dominance by one power over others; and civilians are largely absent from conflicts given that it has become a mainly a technical affair.

In the late 1930s, Schmitt published Völkerrechtliche Grossraumordung [The Order of Large Spaces in International Law], which elaborated his theory of the Grossraum [large space]. At that time, it represented a formal justification for German hegemony in Eastern Europe alongside the border of the Soviet Union. ${ }^{57}$ To achieve such a concrete order, Schmitt conceived of the possibility that the nation-state could morph into large spaces defined in terms of geopolitical boundaries. The Grossraum became an extended territorial space alongside a political ideal that unifies a geographical area

\footnotetext{
${ }^{56}$ George Orwell, Nineteen Eighty-Four : A Novel (New York: Plume, 2003). pp. 200-206

${ }^{57}$ Balakrishnan, The Enemy: An Intellectual Portrait of Carl Schmitt. p. 235
} 
centered on a "Reich." ${ }^{, 58}$ This Reich, or as Samuel Huntington would later call it a "core state," represents "a dynamic political and historical 'idea' which determine[s] what constitute[s] a threat to the collective security of the wider Grossraum." ${ }^{, 59}$ In this geopolitics of the Grossraum, the political or historical idea is to be centered on the friend / enemy distinction. But while Huntington today seeks to illustrate the eventual fragmentation of the international system of "large space orders" along fault lines derived from identity, Schmitt, instead, desired to capture the historical significance of the American Monroe doctrine as a potentiality for a future nomos. His model was that of the United States insofar as it was able to establish a zone of exclusivity in the western hemisphere that precluded the intervention of other powers. The political idea that governed the Monroe doctrine was the antithesis between republicanism and European monarchical regimes: "This is the core of the original Monroe Doctrine, a genuine Grossraum principle, namely the union of politically awakened people, a political idea and, on the basis of this idea, a politically dominant Grossraum excluding foreign intervention." 60 Throughout the $19^{\text {th }}$ and mid-20 $0^{\text {th }}$ centuries, the United States forced other states to recognize this principle of exclusivity within the framework of international legal agreements that started to refer to, in the singular, the "American continent."

\footnotetext{
${ }^{58}$ Ibid. p. 237

${ }^{59}$ Samuel P. Huntington, The Clash of Civilizations and the Remaking of World Order (New York: Simon \& Schuster, 1996).p. 156; Balakrishnan, The Enemy: An Intellectual Portrait of Carl Schmitt. p. 237

${ }^{60}$ Schmitt quoted in Nikolai von Kreitor, The Concept of Grossraum in Carl Schmitt's Jurisprudence ([cited 10/2 2005]); available from http://www.geocities.com/integral_tradition/grossraum.html.
}

${ }^{61} \mathrm{Schmitt}$, The Nomos of the Earth in the International Law of the Jus Publicum Europaeum. p. 282 
Since it is clear that Schmitt's notion of Grossraum was directly premised upon the American Monroe doctrine as a geopolitical order one word of caution and clarification is in order. Although Schmitt developed his idea of Grossraum at the height of the Nazi regime, there remains a large amount of controversy concerning its distinction with the official Nazi policies of Lebensraum developed at about the same time. It was, in particular, this idea that landed Schmitt in trouble with the Allied powers at the end of the Second World War. ${ }^{62}$ The term Lebensraum originated in the work of Friedrich Ratzel and was conceived as a way of measuring the spatial necessity for a state to maintain its economic and political independence. Ratzel's notion morphed into the national socialist justification for extending dominion because of international racial struggles. ${ }^{63}$ The concept of Lebensraum focused on a concept of geographical and racial determinism that guided the necessity of land-appropriation. By contrast, as David Murphy makes clear, Schmitt's concept of Grossraum is radically different insofar as it "emphasize[s] the dominant political idea of a given region." 64

The Grossraum was Schmitt's answers to two problems. One was the lack of a concrete global nomos that governed the political relationships between great powers. The other was the reassertion of the authority and role of the state. But while the American Monroe doctrine transformed itself into a vehicle for legitimate interventions as "police" actions throughout the globe as discussed above, the emergence of a pluriverse of Grossräume, with each Grossraum or large state respecting the other's

\footnotetext{
${ }^{62}$ Balakrishnan, The Enemy: An Intellectual Portrait of Carl Schmitt. p. 254

${ }^{63}$ David Thomas Murphy, The Heroic Earth: Geopolitical Thought in Weimar Germany, 1918-1933 (Kent: Kent State University Press, 1997). pp. 10,245-246; Overy, The Dictators. p. 402

${ }^{64}$ Murphy, The Heroic Earth: Geopolitical Thought in Weimar Germany, 1918-1933. p. 29
} 
sphere of influence would, in Schmitt's view, prefigure the materialization of a new form of international law as concrete order. Gary Ulmen has argued that only this retrieval of the original meaning of the Monroe doctrine and a simultaneous jettisoning of universal and imperialistic pretensions can be the preconditions for a second American century. ${ }^{65}$ The ultimate goal of this concrete order would be to reestablish a bracketing of war, a notion of peace, and a concept of neutrality and non-intervention that would be respected. The enemy would be reestablished as the public enemy, and not the private or personal enemy of today. The utopian aspirations that have plagued humanity throughout the $20^{\text {th }}$ century and early $21^{\text {st }}$ century could only be extinguished when a concrete order reemerges. In a poem called Kunlun, Mao wrote:

If heaven were my garrison, I would draw my sword

And strike you into three pieces:

One as a present for Europe,

One for America,

But one left over for China, And peace would rule the world. ${ }^{66}$

${ }^{65}$ G. L. Ulmen, "Pluralism Contra Universalism," Society 31, no. 5 (1994). p. 36

${ }^{66}$ Quoted in Schmitt, "Theory of the Partisan: A Commentary/Remark on the Concept of the Political." p. 41 


\section{Conclusion}

The aim of this thesis was to articulate a critique of current conceptualizations of international order that had at their source the premise of transforming the political into economic or ethical relationships. It demonstrated, through Schmitt's writings on legal and political theory, the problematic nature of such endeavors. The result, as we are witnessing today, is the propagation of new forms of irregular political relationships that result in an unbracketed form of violence.

Throughout his career as a legal and political theorist, Schmitt sought to devise concrete concepts without recourse to certain modes of normative thinking, or at least by recognizing their danger. He defined the political as being marked by the distinction between public friend and enemy who possess the ability to conduct physical conflict. That extreme or exceptional condition of war between political enemies necessitates a sovereign who decides upon who, at any one time, can become the enemy. Schmitt held that the state of exception was the paramount concept that conditions inquiries into jurisprudence and political theory. A general system of legal norms must be understood as ultimately relying upon a concrete ability to decide when an exceptional situation arises and, concomitantly, when a decision can ultimately restore the state of normalcy. For what is important in Schmitt's understanding of jurisprudence is the certainty that a decision must be taken at a time of urgency and exceptionality. The state of exception for Schmitt is subsumed within the context of a juridical decisionism that restores the break between fact and law. 
Infamous for his embrace of the National Socialist party in 1933, Schmitt fell from grace three years later and turned his scholarly pursuits to questions of international jurisprudence and order. He provided the basis for distinguishing between two different realms of international law: one based on a properly delimited land; another based on a boundless sea that cannot be appropriated or demarcated. For Schmitt, the fundamental constituent act of any politically aware people had consistently been the appropriation of land. It is that action that gave a solid basis for the legitimacy of the political order. That order, as a concrete order, remained the unity between law and land. A necessary corollary to Schmitt's conception of concrete order was the ability to define the exterior limits, or, rather, the proper demarcation of the inside and outside of political and legal orders.

Schmitt's narrative was one of historical constituent moments in world history that gave rise to such international concrete orders. The respublica Christiana was a concrete order centered on Rome, which defined its outside along religious lines. What governed it were the just war principles that would eventually result in its own destruction. The subsequent Jus Publicum Europaeum redefined the concrete order as one composed of a balance between absolute territorially sovereign European princes. Each prince was conceived as the legitimate sovereign in whom the right of war was endowed. However, these princes also formed a community of shared norms that was able to bracket conflict between them. The Jus Publicum Europaeum was ultimately reliant upon an extra-European land-appropriation that initially occurred in the new world. The great wave of European explorers, missionaries, and traders opened the way for the outright occupation and development of distant lands for European monarchs. One 
of the consequences of this development was the establishment of a clearly defined and agreed upon line that demarcated the boundaries of Europe. The norms that were in operation within the concrete European order lost their validity once one crossed the "line" into the new world. The establishment of an outside, then, was the taking out of the state of exception where mere force ruled.

However, the rise of England as a maritime power and the simple fact that the European powers were running out of land to appropriate began to cast doubt on the stability of such a concrete order. The irreconcilable distinction between land warfare and sea warfare began to be felt. The total nature of sea warfare, with its emphasis on prize and blockade law, rendered the distinction between combatants and non-combatants problematic. Moreover, it made the limited aims of war questionable too since war was no longer merely concerned with the acquisition of land. Concurrently, global perceptions about a unified or unifiable globe along economic and ethical lines became fashionable too. Open were the possibilities of conceiving the earth as devoid of war. A politics of "humanity" ensued in which the non-human was constructed as the enemy archetype. The utopian thinking that, lately, has been taken wholeheartedly in the United States with the ambition to rid the earth of tyranny does have its roots in this tension between land and sea.

The fall of the Jus Publicum Europaeum occurring after the First World War would not usher in a concrete order, as was the case after the respublica Christiana. The rupture between order and orientation, as described by Schmitt, would have ominous consequences. For one, it resulted in the reintroduction of conceptions of just wars through the attempt at banning wars between states. But this only served to intensify the 
political. This return to just war resulted in the introduction of "outlaw" states that did not fit the criteria set forth by the status quo powers (the United States, Great Britain, and France) after the First World War. Countries were then to be judged by their internal form of government while their external sovereignty was devalued for the sake of a universalism not rooted in any concrete set of juridical or political concepts. The traditional concepts of war, peace, and neutrality as legal conditions that were concrete and clearly defined during the Jus Publicum Europaeum lost their meaning. The most glaring result was that the line that demarcated the normal state versus the exceptional one began to blur to the point of indistinction. The result was an internalization of the state of exception that resulted in the modern concentration camp as a new modality of global governance and political ordering.

In one of his last published articles entitled "The Legal World Revolution," Schmitt eloquently summarizes the contemporary growing desire for a global revolutionary movement that claims to find its legitimacy and legality in a politics of humanity and progress:

It is possible to conceive of the political unity of humanity through the victory of one industrial superpower over the other or through the union of both with the goal of politically subjugating the total industrial power of the earth. That would be a planetary appropriation of industry. It would differ from the old method of conquest - land and sea appropriation - only in being more intensely aggressive and of greater destructive potential in terms of the means of power utilized. This emphasizes the gap between ethical and moral as opposed to industrial and technical progress. The day world politics comes to earth, it will be transformed into world police power. That is dubious progress! From an operative viewpoint, legality - strategic or tactical - becomes a political and practical problem of the first order. Industrial society is bound to a rationalization which includes the transformation of law into legality. Considering its stability and development, it is extremely sensitive to disturbances, violent interruptions and even sabotage. Whoever works within the law is no disturber, no aggressor, no saboteur. Legality proves to be an ineluctable method of revolutionary change. ${ }^{1}$

\footnotetext{
${ }^{1}$ Schmitt, "The Legal World Revolution." p. 80 emphasis in the original
} 
Thus the concept of legality, decoupled from its spatial moorings in the contemporary order, becomes hostage to and the vehicle for a revolutionary form of violence that no longer can properly articulate a boundary condition. Moreover, contemporary industrial society, as Schmitt cogently argues, is highly sensitized to perturbations and disruptions. Such an event as September $11^{\text {th }}$ gives the impetus to not only radically transform the world for the purpose of effacing the possibility of such an event, but also to destroy the very possibility of any form of resistance to the universal hegemonic order.

Today, we are led to believe in a moralizing ideal, which claims that the spread of freedom, democracy and open markets will transform political divisions between states into a form of perpetual peace. We are told that the forced transformation of "outlaw" regimes will pave the way to a harmony unseen in history. While the prospect of such an end result remains persistently amorphous, vacuous and hubristic, it continues to be a homomorphism of the utopian aspirations from the previous century; what becomes key is not to understand the actual end, but rather the process of implementing the utopian axiology. Schmitt's great merit was to see what all these projects have in common: a persistent will to political truth that translates itself into a murderous program for the soul of humanity. The lack of a concrete nomos since the First World War to govern the international legal system has the consequence of engendering new forms of violence. The irregularity of violence, distinct from the traditional context of armed forces fighting each other over land, is such a consequence. The contemporary problem of global terrorism is such a case where the terrorist becomes the carrier of the political struggle to the point of absolutism. The dueling absolutisms seen today are but a reflection of the disunity between the order and the orientation of the international order. We should not 
be surprised then that the current drive for global revolutionary transformation is met by an evermore trenchant and virulent global-insurgency that reinforces a cycle of terror. 


\section{References}

Agamben, Giorgio. Homo Sacer: Sovereign Power and Bare Life. Translated by Daniel Heller-Roazen. Stanford, Calif.: Stanford University Press, 1998.

- State of Exception. Translated by Kevin Attell. Chicago: University of Chicago Press, 2005.

Anderson, Perry. "Arms and Rights: Rawls, Habermas and Bobbio in an Age of War." New Left Review 31, no. January-February (2005).

- Lineages of the Absolutist State. London: N.L.B., 1974.

Arendt, Hannah. "The Crisis in Culture." In Between Past and Future : Eight Exercises in Political Thought. New York: Penguin Books, 1977.

- Eichmann in Jerusalem : A Report on the Banality of Evil. New York: Penguin Books, 1994.

- The Human Condition. 2nd ed. Chicago: University of Chicago Press, 1998.

- On Revolution. Westport: Greenwood Press, 1982.

- The Origins of Totalitarianism. New York: Harcourt, 1994.

—. "Truth and Politics." In Between Past and Future : Eight Exercises in Political Thought. New York: Penguin Books, 1977.

—. "What Is Authority?" In Between Past and Future : Eight Exercises in Political Thought. New York: Penguin Books, 1977.

—. "What Is Freedom?" In Between Past and Future : Eight Exercises in Political Thought. New York: Penguin Books, 1977.

Aristotle. Ethics. Translated by J. A. K. Thomson. New York: Penguin Books, 1976.

Bacevich, A. J. The New American Militarism : How Americans Are Seduced by War. New York: Oxford University Press, 2005.

Balakrishnan, Gopal. The Enemy: An Intellectual Portrait of Carl Schmitt. New York: Verso, 2000. 
_. "Overcoming Emancipation." New Left Review 19 (2003).

Bendersky, Joseph W. Carl Schmitt, Theorist for the Reich. Princeton, N.J.: Princeton University Press, 1983.

- "The Definite and the Dubious: Carl Schmitt's Influence on Conservative Political and Legal Theory in the Us." Telos Winter 2002 (2002): 33-48.

Benhabib, Seyla. The Reluctant Modernism of Hannah Arendt. Thousand Oaks: Sage Publications, 1996.

Benjamin, Walter. "Critique of Violence." In Reflections: Essays, Aphorisms, Autobiographical Writings, edited by Peter Demetz. New York: Schocken Books, 1989.

- Illuminations. Translated by Harry Zohn. Edited by Hannah Arendt. New York: Schocken Books, 1986.

Blumenberg, Hans. The Legitimacy of the Modern Age. Cambridge: MT Press, 1983.

Bolsinger, Eckard. The Autonomy of the Political: Carl Schmitt's and Lenin's Political Realism. Westport: Greenwood Press, 2001.

Bradley, Owen. A Modern Maistre: The Social and Political Thought of Joseph De Maistre. Lincoln: University of Nebraska Press, 1999.

Bredekamp, Horst. "From Walter Benjamin to Carl Schmitt, Via Thomas Hobbes." Critical Inquiry 25, no. Winter (1999): 247-66.

Brunkhorst, Hauke. "The Right to War: Hegemonial Geopolitics or Civic Constitutionalism?" Constellations 11, no. 4 (2004): 512-26.

Bush, George W. The President's State of the Union Address 2002 [cited 10/2 2005]. Available from http://www.whitehouse.gov/news/releases/2002/01/2002012911.html. Second Term Inaugural Address 2005 [cited 02/08/2005. Available from http://www. whitehouse.gov/news/releases/2005/01/20050120-1.html. Supporting Emerging Democracies 2005 [cited 10/2 2005]. Available from http://www.state.gov/s/crs/rls/rm/46818.htm. 
Buzbee, Sally. Bush's Use of Word 'Crusade' a Red Flag Associated Press, September 18, 2001 [cited 10/3 2005]. Available from http://seattlepi.nwsource.com/national/39266 crusadel 8 .shtml.

Carr, Edward Hallett. The Twenty Years' Crisis, 1919-1939: An Introduction to the Study of International Relations. New York: Harper Torchbooks, 1964.

Carty, Anthony. "Carl Schmitt's Critique of Liberal International Legal Order between 1933 and 1945." Leiden Journal of International Law 14 (2001): 24-76.

Cassirer, Ernst. The Myth of the State. New Haven: Yale university press, 1946.

Chytry, Joseph. The Aesthetic State: A Quest in Modern German Thought. Berkeley: University of California Press, 1989.

Cristi, Renato. Carl Schmitt and Authoritarian Liberalism: Strong State, Free Economy, Political Philosophy Now. Cardiff: University of Wales Press, 1998.

Cumin, David. Thalassopolitique: Carl Schmitt Et La Mer 2000 [cited 07-10-2005 2005]. Available from http:/www.stratisc.org/pub/pn/PN7 Cumin.html.

Dallmayr, Fred R. The Other Heidegger, Contestations. Ithaca: Cornell University Press, 1993.

Derrida, Jacques. Politics of Friendship. New York: Verso, 1997.

Donoso Cortes, Juan. Selected Works of Juan Donoso Cortes. Translated by Jeffrey P. Johnson. Edited by Jeffrey P. Johnson. Westport: Greenwood Press, 2000.

Drury, Shadia B. Alexandre Kojève : The Roots of Postmodern Politics. New York: St. Martin's Press, 1994.

_Leo Strauss and the American Right. 1st ed. New York: St. Martin's Press, 1997.

Durkheim, Emile. Selected Writings. Translated by Anthony Giddens. Edited by Anthony Giddens. Cambridge: Cambridge University Press, 1972.

Dyzenhaus, David. Legality and Legitimacy: Carl Schmitt, Hans Kelsen and Hermann Heller in Weimar. Oxford: Claredon Press, 1997.

Feenberg, Andrew. Questioning Technology. New York: Routledge, 1999. 
Foucault, Michel. The History of Sexuality. V.1 vols. New York: Vintage Books, 1988.

- Society Must Be Defended : Lectures at the Collège De France, 1975-76.

Translated by David Macey. Edited by Mauro Bertani, Alessandro Fontana and François Ewald. New York: Picador, 2003.

Freund, Julien. "Schmitt's Political Thought." Telos, no. 102 (1995): 11-31.

Frye, Charles E. "Carl Schmitt's Concept of the Political." The Journal of Politics Vol. 28, no. 4 (1966): 818-30.

Fukuyama, Francis. The End of History and the Last Man. Toronto: Free Press, 1992.

Galli, Carlo. "The Critic of Liberalism: Carl Schmitt's Antiliberalism: Its Theoretical and Historical Sources and Its Philosophical and Political Meaning." Cardozo Law Review 21, no. 1597 (2000).

Gottfried, Paul. Carl Schmitt : Politics and Theory, Contributions in Political Science, No. 264. New York: Greenwood Press, 1990.

Habermas, Jürgen. Bestiality and Humanity: A War on the Border between Law and Morality 2000 (1999) [cited 09/21/2005. Available from http://www.theglobalsite.ac.uk'press/011 habermas.htm.

- . The Horrors of Autonomy: Carl Schmitt in English." In The New Conservatism : Cultural Criticism and the Historians' Debate, 128-39. Cambridge: MIT Press, 1992.

__ "Kant's Idea of Perpetual Peace: At Two Hundred Years Historical Remove." In The Inclusion of the Other: Studies in Political Theory, edited by Ciaran Cronin and Pablo De Greiff. Cambridge: MIT Press, 1998.

Hardt, Michael, and Antonio Negri. Empire. Cambridge: Harvard University Press, 2000.

- Multitude: War and Democracy in the Age of Empire. New York: The Penguin Press, 2004.

Heidegger, Martin. The Question Concerning Technology and Other Essays. Translated by William Lovitt. New York: Harper \& Row, 1977. 
Herz, John H. "Looking at Carl Schmitt from the Vantage Point of the 1990's." Interpretation 19, no. 3 (1992): 307-14.

Hobbes, Thomas. Leviathan : With Selected Variants from the Latin Edition of 1668.

Edited by E. M. Curley. Indianapolis: Hackett Pub. Co., 1994.

Holmes, Stephen. The Anatomy of Antiliberalism. Cambridge, Mass.: Harvard University Press, 1993.

Honig, Bonnie. Political Theory and the Displacement of Politics, Contestations. Ithaca: Cornell University Press, 1993.

Horkheimer, Max, and Theodor W. Adorno. Dialectic of Enlightenment: Philosophical Fragments. Translated by Gunzelin Schmid Noerr. Stanford: Stanford University Press, 2002.

Huntington, Samuel P. The Clash of Civilizations and the Remaking of World Order. New York: Simon \& Schuster, 1996.

Husserl, Edmund. The Crisis of European Sciences and Transcendental Phenomenology: An Introduction to Phenomenological Philosophy. Evanston,: Northwestern University Press, 1970.

Israel General 'Avoids Uk Arrest' 2005 [cited 09/17 2005]. Available from http://news.bbc.co.uk/2/hi/uk_news/4237620.stm.

Joas, Hans. War and Modernity. Translated by Rodney Livingstone. Cambridge: Polity Press, 2003.

Kalyvas, Andreas. "From the Act to the Decision: Hannah Arendt and the Question of Decisionism." Political Theory 32, no. 3 (2004): 320-46.

Kantorowicz, Ernst Hartwig. The King's Two Bodies: A Study in Mediaeval Political Theology. Princeton: Princeton University Press, 1957.

Kaplan, Gisela T., and Clive S. Kessler. Hannah Arendt : Thinking, Judging, Freedom. Boston: Allen \& Unwin, 1989.

Kennedy, Ellen. "Carl Schmitt and the Frankfurt School." Telos 71 (1987): 37-66. 
Kissinger, Henry. A World Restored; Metternich, Castlereagh, and the Problems of Peace, 1812-22. Boston,: Houghton Mifflin, 1973.

Kojève, Alexandre. Introduction to the Reading of Hegel. Edited by Raymond Queneau. New York,: Basic Books, 1969.

Koselleck, Reinhart. Critique and Crisis: Enlightenment and the Pathogenesis of Modern Society. Cambridge: MIT Press, 1988.

Koskenniemi, Martii. The Gentle Civilizer of Nations: The Rise and Fall of International Law 1870-1960. Cambridge: Cambridge University Press, 2002.

—_. "International Law as Political Theology: How to Read Nomos Der Erde?" Constellations 11, no. 4 (2004): 492-511.

Kreide, Regina. "Book Review: The Law of Peoples." Constellations 9, no. 4 (2002).

Kreitor, Nikolai von. The Concept of Grossraum in Carl Schmitt's Jurisprudence [cited 10/2 2005]. Available from http://www.geocities.com/integral tradition'grossraum.html.

Kuper, Andrew. "Rawlsian Global Justice: Beyond the Law of Peoples to a Cosmopolitan Law of Persons." Political Theory 28, no. 5 (2000).

Lauterpacht, Hersch. The Function of Law in the International Community. New York: Garland Publishing, 1973.

Lebow, Richard Ned. The Tragic Vision of Politics: Ethics, Interests, and Orders. New York: Cambridge University Press, 2003.

Ledeen, Michael. American Power--for What? Commentary, 2000 [cited 10/2 2005]. Available from http://www.aei.org/publications/pubID.11141, filter.all/pub detail.asp.

Lefort, Claude. Democracy and Political Theory. Minneapolis: University of Minnesota Press, 1988.

Lilla, Mark. "The Enemy of Liberalism." The New York Review of Books, May 151997.

Losurdo, Domenico. Heidegger and the Ideology of War: Community, Death, and the West. Translated by Jon and Marcella Morris. Amherst: Humanity Books, 2001. 
Löwith, Karl. Meaning in History. Chicago: University of Chicago Press, 1957.

—_. "The Occasional Decisionism of Carl Schmitt." In Martin Heidegger and European Nihilism, edited by Richard Wolin. New York: Columbia University Press, 1995.

McCormick, John P. Carl Schmitt's Critique of Liberalism: Against Politics as Technology. Cambridge: Cambridge University Press, 1997.

—. "Fear, Technology, and the State: Carl Schmitt, Leo Strauss and the Revival of Hobbes in Weimar and National Socialist Germany." Political Theory Vol. 22, no. 4 (1994): 619-52.

- "Political Theory and Political Theology: The Second Wave of Carl Schmitt in English." Political Theory 26, no. 6 (1998): 830-54.

Meier, Heinrich. Carl Schmitt \& Leo Strauss: The Hidden Dialogue. Chicago: University of Chicago Press, 1995.

- The Lesson of Carl Schmitt: Four Chapters on the Distinction between Political Theology and Political Philosophy. Chicago: University of Chicago Press, 1998.

Meinecke, Friedrich. Machiavellism: The Doctrine of Raison D'etat and Its Place in Modern History. New Brunswick, N.J.: Transaction Publishers, 1998.

Morgenthau, Hans Joachim. In Defense of the National Interest: A Critical Examination of American Foreign Policy. New York,: Knopf, 1951.

- La Notion Du "Politique" : Et La Theorie Des Differends Internationaux. Paris: Recueil Sirey, 1933.

Politics among Nations: The Struggle for Power and Peace. Edited by Kenneth W. Thompson. 6th ed. New York: Knopf : Distributed by Random House, 1985.

. "Positivism, Functionalism, and International Law." The American Journal of International Law 34, no. 2 (1940): 260-84.

-. Scientific Man Vs. Power Politics. Chicago: University of Chicago Press, 1974.

Müller, Jan-Werner. A Dangerous Mind: Carl Schmitt in Post-War European Thought. New Haven: Yale University Press, 2003. 
_. "Myth, Law and Order: Schmitt and Benjamin Read Reflections of Violence." History of European Ideas 29 (2003): 459-73.

Murphy, David Thomas. The Heroic Earth: Geopolitical Thought in Weimar Germany, 1918-1933. Kent: Kent State University Press, 1997.

Nancy, Jean-Luc. "War, Right, Sovereignty - Techne." In Being Singular Plural, 101-43. Stanford: Stanford University Press, 2000.

Norris, Andrew. "Carl Schmitt on Friends, Enemies and the Political." Telos, no. 112 (1998): 68-89.

—. "Carl Schmitt's Political Metaphysics: On the Secularization of the 'Outermost Sphere'." Theory \& Event 4, no. 1 (2000).

Norton, Anne. Leo Strauss and the Politics of American Empire. New Haven Conn. ; London: Yale University Press, 2004.

Novak, Michael. "Global Liberty." National Review, January 20, 2005.

Ojakangas, Mika. "Carl Schmitt's Real Enemy: The Citizen of the Non-Exclusive Democratic Community?" The European Legacy 8, no. 4 (2003): 411-24.

Oneal, John R., and Russet Bruce. "The Pacific Benefits of Democracy, Interdependence, and International Organization, 1885-1992." World Politics 51, no. 1 (1999): 137.

Orwell, George. Nineteen Eighty-Four : A Novel. New York: Plume, 2003.

Overy, Richard. The Dictators. New York: W.W. Norton \& Company, 2004.

Pagden, Anthony. The Fall of Natural Man: The American Indian and the Origins of Comparative Ethnology. Cambridge: Cambridge University Press, 1986.

Palaver, Wolfgang. "Carl Schmitt on Nomos and Space." Telos, no. 106 (1996): 105-28.

Passerin d'Entráeves, Maurizio. The Political Philosophy of Hannah Arendt. London ; New York: Routledge, 1994.

Paul Piccone, and Ulmen Gary. "Uses and Abuses of Carl Schmitt." Telos Winter 2002 (2002): 2-32. 
Pitts, Jennifer. A Turn to Empire: The Rise of Imperial Liberalism in Britain and France. Princeton: Princeton University Press, 2005.

Rasch, William. "Human Rights as Geopolitics; Carl Schmitt and the Legal Form of American Supremacy." Cultural Critique 54, no. 1 (2003): 120-47.

- "Introduction: Carl Schmitt and the New World Order." South Atlantic Quarterly 104 , no. 2 (2005).

Rawls, John. The Law of Peoples: With "the Idea of Public Reason Revisited". Cambridge: Harvard University Press, 1999.

Reid, Julian. "Foucault on Clausewitz: Conceptualizing the Relationship between War and Power." Alternatives 28 (2003): 1-28.

Relyea, Harold C. "National Emergency Powers." In 98-505 GOV: Congressional Research Service, 2001.

Scheuerman, William E. Carl Schmitt: The End of Law. Lanham: Rowman \& Littlefield Publishers, 1999.

_. "International Law as Historical Myth." Constellations 11, no. 4 (2004).

Schmidt, Dennis J. On Germans \& Other Greeks: Tragedy and Ethical Life. Bloomington: Indiana University Press, 2001.

Schmitt, Carl. "The Age of Neutralizations and Depoliticizations." Telos, no. 96 (1993 (1929)): 130-42.

—. "Appropriation/Distribution/Production: Toward a Proper Formulation of Basic Questions of Any Social and Economic Order." Telos, no. 95 (1993).

The Concept of the Political. Chicago: University of Chicago Press, 1996.

- The Crisis of Parliamentary Democracy, Studies in Contemporary German Social Thought. Cambridge, Mass.: MIT Press, 1985.

_. La Dictature, L'ordre Philosophique;. Paris: Éditions du Seuil, 2000.

_L Land and Sea. Washington, DC: Plutarch Press, 1997. 
—. "The Legal World Revolution." Telos, no. 27 (1987).

- The Leviathan in the State Theory of Thomas Hobbes: Meaning and Failure of a Political Symbol. Westport, Conn.: Greenwood Press, 1996.

- The Nomos of the Earth in the International Law of the Jus Publicum Europaeum. Translated by G. L. Ulmen. New York: Telos Press, 2003.

- On Three Types of Juristic Thought. Translated by Joseph W. Bendersky. Westport: Praeger Publishers, 2004.

—. "The Plight of European Jurisprudence." Telos 83 (1990): 35-70.

—. Political Romanticism. Cambridge: MIT Press, 1986.

- Political Theology: Four Chapters on the Concept of Sovereignty. Cambridge: MIT Press, 1985.

- Politische Theologie I I. Die Legende Von Der Erledigung Jeder Politischen Theologie. Berlin,: Duncker u. Humblot, 1970.

- Roman Catholicism and Political Form. Translated by G. L. Ulmen. Westport: Greenwood Press, 1996.

- State, Movement, People: The Triadic Structure of the Political Unity. Translated by Simona Draghici. Corvallis: Plutarch Press, 2001.

- "Theory of the Partisan: A Commentary/Remark on the Concept of the Political." New Centennial Review 4, no. 3 (2004 (1963)): 1-78.

_. "Total Enemy, Total War, Total State." In Four Articles: 1931-1938, edited by Simona Draghici. Corvallis: Plutarch Press, 2001.

_. Verfassungslehre. 8. Aufl. ed. Berlin: Duncker \& Humblot, 1993.

-War/Non-War?: A Dilemma. Translated by Simona Draghici. Corvallis, OR: Plutarch Press, 2003.

Schwab, George. The Challenge of the Exception: An Introduction to the Political Ideas of Carl Schmitt between 1921 and 1936. 2nd ed, Contributions in Political Science, No. 248. New York: Greenwood Press, 1989. 
Siegfried, Marck. "Neo-Machiavellism and Ethical Nihilism." Ethics Vol. 51, no. 2 (1941): 185-99.

Simpson, Gerry. Great Powers and Outlaw States. Cambridge: Cambridge University Press, 2004.

Skinner, Quentin. The Foundations of Modern Political Thought. Cambridge: Cambridge University Press, 1978.

Spengler, Oswald. The Decline of the West. Translated by Charles Francis Atkinson. New York,: A., 1926.

Stirk, Peter M. R. "Carl Schmitt's Enemy and the Rhetoric of Anti-Interventionism." The European Legacy 8, no. 1 (2003): 21-36.

Strauss, Leo. "Notes on Carl Schmitt: The Concept of the Political." In The Concept of the Political, edited by George Schwab. Chicago: University of Chicago Press, 1996.

- On Tyranny. Edited by Victor Gourevitch and Michael S. Roth. Rev. and expanded ed. New York: Free Press, 1991.

- The Political Philosophy of Hobbes: Its Basis and Its Genesis. Chicago: University of Chicago Press, 1984.

- Spinoza's Critique of Religion. New York,: Schocken Books, 1965.

Stromseth, Jane. "Rethinking Humanitarian Intervention: The Case for Incremental Change." In Humanitarian Intervention: Ethical, Legal, and Political Dilemas, edited by J.L. Holzgrefe and Robert O. Keohane. Cambridge: Cambridge University Press, 2003.

Todorov, Tzvetan. The New World Disorder: Reflections of a European. Malden: Polity, 2005 .

Tönnies, Ferdinand. Hobbes Leben Und Lehre. Stuttgart,: F. Frommanns verlag (E. Hauff), 1896.

Tuchscherer, Emmanuel. "Le Decisionnisme De Carl Schmitt: Theorie Et Rhetorique De La Guerre." Mots, no. 73 (2003): 25-43. 
Ulmen, G. L. "American Imperialism and International Law: Carl Schmitt on the Us in World Affairs." Telos 72 (1987): 43-71.

—. "Just Wars or Just Enemies." Telos 109 (1996): 99-112.

_. "Pluralism Contra Universalism." Society 31, no. 5 (1994): 32-36.

Vatter, Miguel. "Politics as War: A Formula for Radical Democracy." Multitudes, no. 9 (2002).

- "Strauss and Schmitt as Readers of Hobbes and Spinoza." The New Centennial Review 4, no. 3 (2004): 161-214.

Villa, Dana Richard. Arendt and Heidegger: The Fate of the Political. Princeton: Princeton University Press, 1996.

- Politics, Philosophy, Terror: Essays on the Thought of Hannah Arendt. Princeton: Princeton University Press, 1999.

Weber, Max. Economy and Society. Berkeley: University of California Press, 1978.

From Max Weber: Essays in Sociology. Translated by Hans Heinrich Gerth and C. Wright Mills. Edited by Hans Heinrich Gerth and C. Wright Mills. New York: Oxford University Press, 1958.

- The Protestant Ethic and the "Spirit" of Capitalism and Other Writings. Translated by Gordon C. Wells. Edited by P. R. Baehr. New York: Penguin Books, 2002.

Wolin, Richard. "Carl Schmitt, Political Existentialism, and the Total State." Theory and Society 19, no. 4 (1990): 389-416.

- "Carl Schmitt: The Conservative Revolutionary Habitus and the Aesthetics of Horror." Political Theory Vol. 20, no. 3 (1992): 424-47.

Wolin, Sheldon S. Politics and Vision: Continuity and Innovation in Western Political Thought. Expanded ed. Princeton: Princeton University Press, 2004.

Woods, Roger. The Conservative Revolution in the Weimar Republic. New York: St Martins Press, 1996. 
Wright, Quincy. A Study of War. Edited by Louise Leonard Wright. Abridged ed. Chicago: University of Chicago Press, 1983. 